\title{
Entering the Ionian: The Island of Corfu
}

[...] entering the straits of Corfu we saw a big ruined city, called Cassopo, which is said to have been destroyed by a dragon $[. . .]^{1}$

[...] we arrived at the port of Corfu. This is a city built on an island, presently dominated by the Signoria, and, according to what we read in all the cosmographies, it was named Corcyra and inhabited by the Phaiacs $[\ldots]^{2}$

The small natural harbour of Kassiopi is located in the north-east of Corfu (Fig. 1). The area has been inhabited since the 4th or the 2nd century ВС and it was a thriving city during the Roman period. ${ }^{3}$ The castle, which still lies in ruins on top of the hill above the port, was built on the debris of a Roman one in the Byzantine era, most probably during the 12th century, and was destroyed by the Venetians in 1386, when they occupied the port of Kassiopi. ${ }^{4}$ From the Early Christian period the church of the Virgin Kassopitra stood near the harbour, on a spot visible from the ships passing by (Fig. 2).

The port and the church of the Virgin in Kassiopi are examined separately from the town of Corfu, not only because they are treated this way by the travellers and pilgrims, but also because of their importance in the pilgrims' holy itinerary. Located $37 \mathrm{~km}$ away, and hardly accessible by land, and 18 nautical

1 Santo Brasca (1480): '[...] intrando nel canale de Corfo trovassemo una terra grande, ma destruta, chiamata Casoppo, la quale se dice esser desfacta da uno dracone [...]'. Momigliano Lepschy 1966, 59. All translations are my own unless otherwise stated.

2 Antonio da Crema (1486): '[...] nel porto di Corfù si ritrovassimo giunti. Questa è cità in insula edificata, al presente dominiata per la Signoria, e, per quanto se lege in tutti li gosmographi, fu nominata Corcyra et habitata da li Pheaci [...]'. Nori 1996, 45 .

3 Voyadjis and Raptaki 2007, 29; Dakararis 1989, 9.

4 Linardos 1976, 15, 20; Agoropoulou-Birbili 1982, 222; Voyadjis and Raptaki 2007, 29; Asonitis 1999, 122; Matton 1960, 73. 


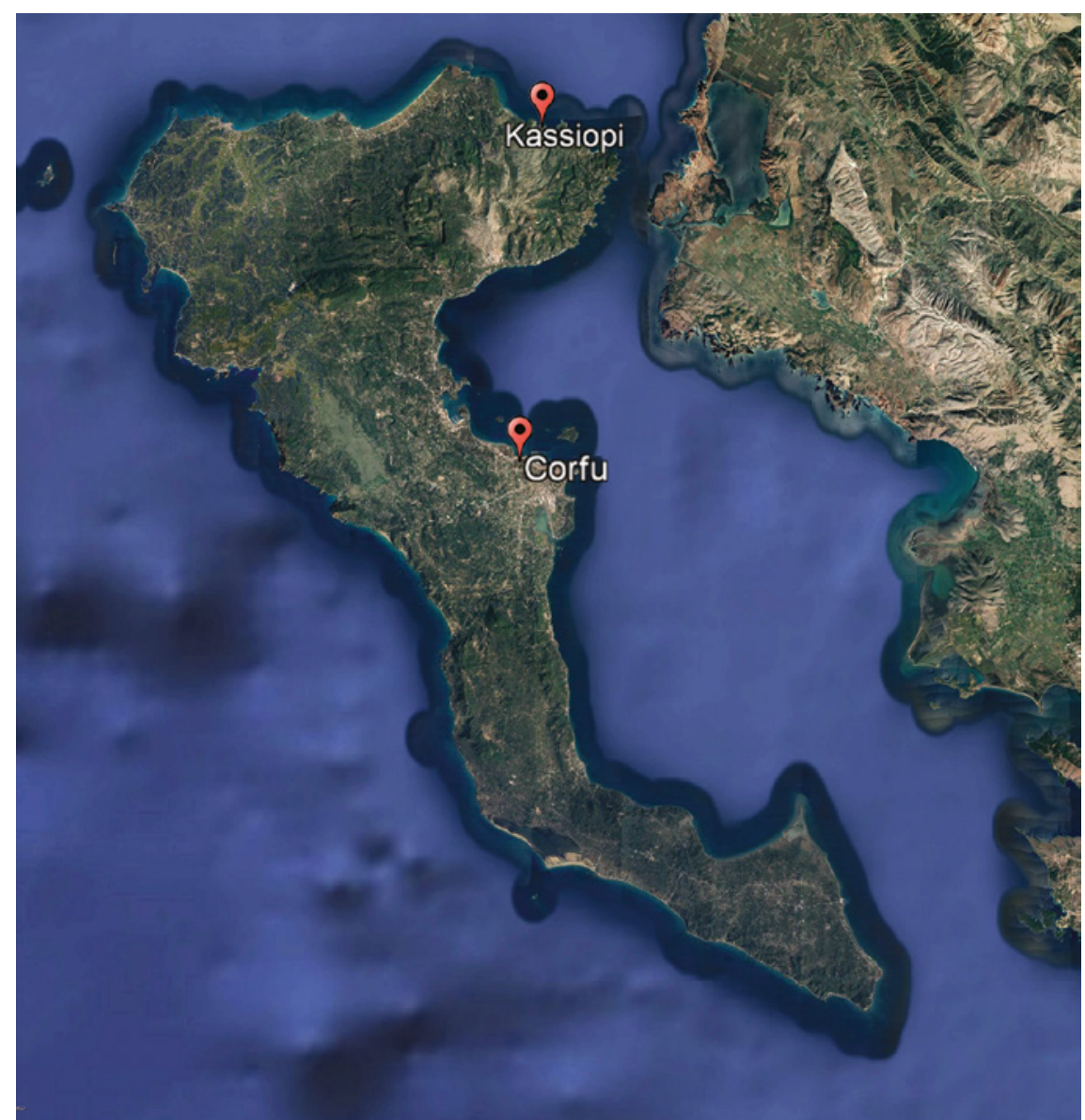

FIGURE 1 Map of the island of Corfu, indicating the locations of Kassiopi and the city of Corfu

miles by sea from the town of Corfu, Kassiopi is perceived as an autonomous site, completely separated from the port and town of the capital city of the island. Kassiopi is the first site on Corfu, and by extension Greece, that is mentioned in the travelogues. It is a liminal place both in geographical as well as in cultural terms, since it was the first stop of the galleys as they left Latin Europe and entered the former Byzantine territory of Greece.

The veneration of the Virgin of Kassiopi as a protector of ships and sailors existed long prior to the arrival of the Venetians, but it was mainly, if not only, associated with the seafarers sailing through the area. It was after the 14th century that the cult surpassed its regional character and was integrated into the 


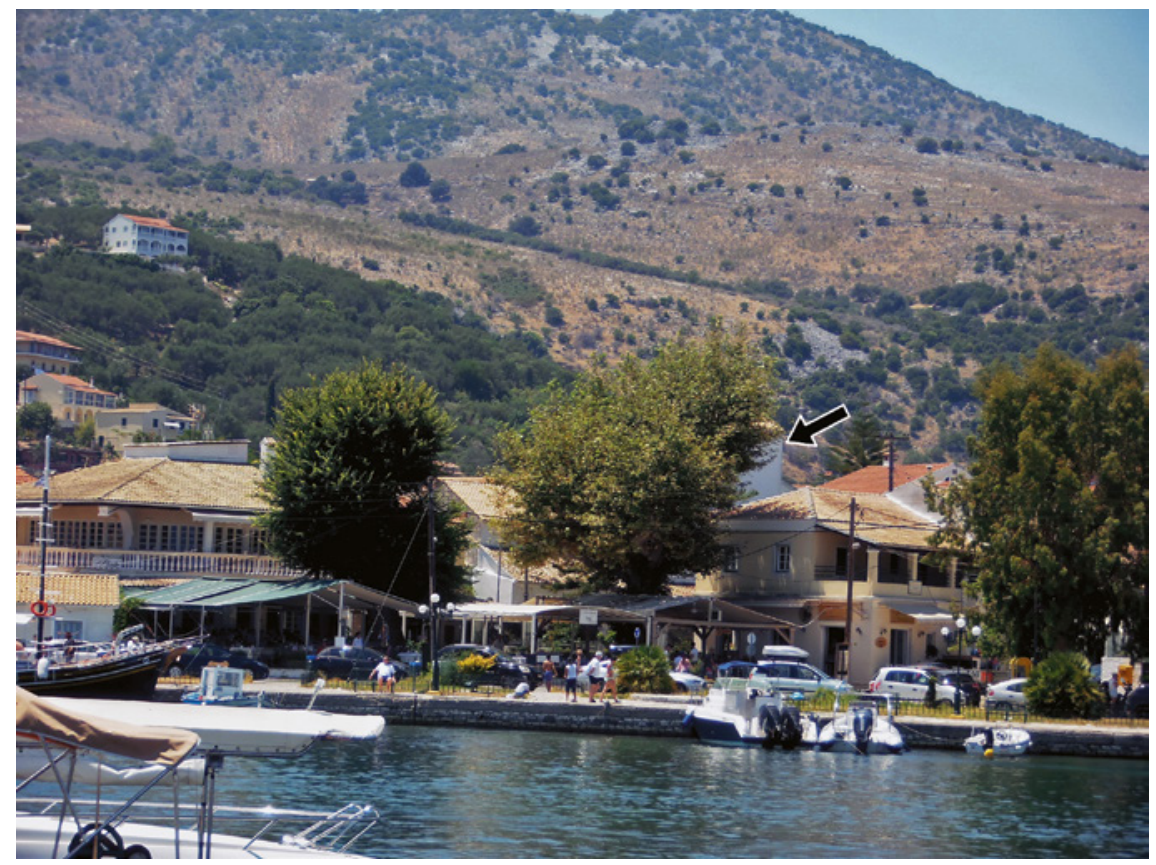

FIGURE 2 The church of the Virgin Kassopitra, Corfu, as seen from the port

holy topography of the pilgrims on their way to Jerusalem. ${ }^{5}$ The initial grounds for the insertion of the site into this network of worship-worthy shrines were strictly practical and connected to the marine experience of the pilgrims and the legends that many of them attest, as conveyed to them by the seafarers.

Sailing through the Adriatic, right before entering the Ionian Sea and the territory of Greece, pilgrims' galleys would have to pass through the perilous straits between the island of Corfu and the mainland. Located at the north end of these straits, Kassiopi, a natural harbour well known to sailors as a safe anchorage, is referred to by most of the pilgrims, always in connection with the church of the Virgin situated a 'stone's throw away from the sea' ${ }^{6}$

The straits the galleys had to pass through near the coast of Corfu, as narrow as 1.3 nautical miles at some points, have a shallow and sandy area dotted with

5 The church of the Virgin in Kassiopi was also part of a sub-network in the framework of the larger network of the sacred sites along the sea route from Venice to the Holy Land, one of Marian cult related sites that dot the navigation route. About the sacred sites on the sea route from Venice to the Holy Land, see Bacci 2004b; Bacci 2012. About the Marian cult sites on the same route, see Bacci et al. 2017.

6 Nicola de Martoni (1394-1395): 'Est prope mare per jactum lapidis.' Piccirillo 2003, 164. 
clusters of rocks, called the Serpa. ${ }^{7}$ The pilgrim Georges Lengherand (14851486), mayor of Mons, describes the straits and the difficulty of sailing through them: 'On Wednesday, the 28 th day of June, because of the poor wind we could not sail to a distance and we found ourselves between the rocks and mountains of the coasts of Turkey and many rocks surrounded by the sea towards the opposite coast [of Corfu].8 The Serpa, depending on the currents, either emerges or sinks, being thus visible or not. ${ }^{9}$ The crossing was equally difficult near the coast of Albania and Butrint. Bearing in mind that during the studied period nautical instruments and charts were of questionable usefulness, the sailors thus tried to navigate along the coast relying on their empirical visual memory and, of course, on the wind, so one can imagine the dangers of sailing through the straits.

The perilous navigation of these narrow straits is emphasised in the portolan charts and the isolarii of the time, and the port of Kassiopi is suggested as a safe anchorage, while most of them also mention the church of the Virgin. ${ }^{10}$ The port also had springs of fresh water, vital for the galleys and their passengers; thus the evocation of the site in the Santa Parola, a seafarer's prayer sung in times of danger and evoking saints and sites on the sea route leading from the West to the East, seems to come as a natural consequence. ${ }^{11}$ Very often, if the winds were not favourable, the galleys were obliged to stay in or even return to the port of Kassiopi and wait for the wind to turn 'in a state of ennui and melancholy'.12 Many pilgrims mention this dangerous passage: Bernhard

The word 'Serpa' is considered to derive either from the Latin word serpo, to crawl, or the Albanian word sarp, stone. Bounias 1954, 218; Tsitsas 1973, 64-65.

8 'Le mercredy, XXVIII ${ }^{\mathrm{e}}$ jour dudit mois de juing, à cause que le vent nous fut petit, ne peusmes faire ce jour ghaires de chemin, mais nous retrouvasmes arrière les roches et montaignes du costé de la Turquie et mesmes pluiseurs roches enclavées en playnne mer de l'autre costé [...].' Ménilglaise 1861, 94.

9 Marieni 1830, 472.

10 Portolan of Gratiosus Benincasa (1435-1445): 'El porto de Chasopoli sie sotto ala terra e la terra sie lontana dala marina meza balestrata e in questo porto a madona santa maria.' Kretschmer 1909, 418.

11 Anonymous, Lo itinerario de andare in Hierusalem (1469): 'Qua piliamo di l'aqua dolce, che certo in galea no n'era di bona.' Longo 2007, 153. About the Santa Parola litany, see Bacci 2004b, 223-248; Bacci 2013b; Kretschmer 1909, 320, 516, 418; Bayer 2007, 8; Falchetta 2001, 13; Selmi 2001, 18; Livieratos 2001, 29-30, 34.

12 Georges Lengherand of Mons (1485-1486): 'Nous n'eusmes pas cheminé demie mille quand le vent tourna tout contraire, et à ceste cause failly avaller le voille et ancrer de rechief, car nous estions avironnez de roches: et demourâmes en cest estat, obstant que c'estoit dommage à nostre patron pour la despence, jusques à environ une heure après midy que lors feymes voile [...].' Ménilglaise 1861, 94; Philippe de Voisins: 'Et quand feurent allés et navigués en la mer cinquante mille avant, feurent constraintz retourner 
von Breydenbach (1483-1484) wrote that, 'If we had not had a good wind in this channel, we would have had to face great fears and worries. Because this channel has a greedy, unfathomable throat, which from time to time attracts the ships and devours them [...]'; while some pilgrims faced turbulent sea and bad weather in the area, and the fear for their life is vividly reflected in their travelogues. ${ }^{13}$ Alessandro di Filippo Rinuccini, travelling in 1474, describes the pilgrims' fear as they were trying to protect themselves during a storm by praying and comforting each other. ${ }^{14}$

Consequently, the straits between Corfu and the mainland and the harbour of Kassiopi are closely linked together by an opposition: the danger of the passage and the safety (both earthly and divine) of the port. This antithesis is reflected in the legend narrated by the seafarers - and reproduced by most of the travelogues - about the dragon or sea monster that destroyed the ancient town of Kassiopi to punish the sinful inhabitants for their 'sin of sodomy', sparing only the lives of the people of the church. ${ }^{15}$ The dragon supposedly lived in the sea near the town, under what is referred to as Scopulus Serpenti, the Dragon's Rock, which could possibly be identified as the area of the so-called Serpa, dotted with clusters of rocks that emerge from the sea and sink back again. Even the name Serpa could, for the Western pilgrims, bring to mind the word serpent, one that seafarers claimed still lived in the area, and some alleged to have seen. ${ }^{16}$ Other narratives mention that the dragon lived in the

ariere a cause de la tourmente jusques a Nostre-Dame de Gasopie en ladicte isle de Torffo, ou demurarent iij jours en grand enuy et melencolie.' Tamizey de Larroque 1883, 39-40.

13 'Hätten wir in diesem Kanal keinen guten Wind gehabt, dann hätten wir große Ängste und Sorgen ausgestanden. Denn dieser Kanal besitzt einen gierigen, unergründlichen Schlund, der die Schiffe anzieht und von Zeit zu Zeit verschlingt.' Mozer 2010, 649.

14 'I pellegrini, la magior parte, stavan sotto coverta, non a dormire ma a racomandarsi a Iddio e a sancta Cecilia che piacesse di liberarne da tal fortuna et chi diceva l'uficio mattutinale, altri dicevano psalmi, altri orationi divote, chi invocava uno sancto et chi $\mathrm{j}^{\circ}$ altro, chi confortava l'uno l'altro a stare di buon animo et non temere, sperando in Dio che.cci farebbe misericordia; altri, vinti dal travaglio del mare, stavano smarriti et mezzi balordi.' Calamai 1993, 85. The German Dominican friar Felix Fabri (1480, 1483-1484) also writes: 'Mansit autem tempestas haec per totam noctem, et in magnis angustiis stetimus.' Hassler 1843-1849, vol. 3 , 35 .

15 Ulrich Brunner (1470): ‘[... dobey hat ein stat gelegenn, dye meure sten noch, die do verstoret ist worden von einem trachen propter peccatum sodomiticum, und etliche frumme leut, die in der selben stat gewest sein, habenn unser frawen angeruffen, und als der trach ausz dem durckischen gepirg kumen ist, do ist ein wint kommen und hat den trachen zu trumern an ein fels geslagen, und an der selben stat ist die obgenant kirche in der ere unser liebenn frawen gebawet [...]. Röhricht 1906, 21. Also Felix Fabri and Paul Walther Guglingen: Hassler 1843-1849, vol. 3, 352; Sollweck 1892, 77.

16 Botho zu Stolberg (1493-1494): '[...] vnd dasz selbige thier haben dy schifluthe noch inwendigk vunff Jarn adder nehir gesehin also sy ons vnderrichten'. Jacobs 1868, 195-196. 
mountains of the opposite shore, possibly hinting at the dangerous currents near the Strait of Butrint. ${ }^{17}$ Almost a century after the destruction of the castle by the Venetians in 1386, the legend of a dragon with burning breath appeared, probably mirroring the impression provoked in the defenders of the castle by the use of cannon and gunpowder: 'In this small town near the sea, there was a castle and a rock where a dragon lived. The dragon flew every day over the town and with his fiery breath polluted the air, and the inhabitants died. Those who survived left the town, which remained desolated.'18

\subsection{The Church of the Virgin Kassopitra}

As far as the celebrated church of the Virgin Kassopitra is concerned, its actual date of construction is uncertain. It was probably built in the Early Christian period as a three-aisled basilica on the site of the pre-existing temple of Cassios Zeus. ${ }^{19}$ There were two side chapels attached to the main building, one to the north, dedicated to St George, and one to the south, dedicated to St Sophia. The chapel of St Sophia was completely destroyed, probably in 1537 during the first Ottoman siege of Corfu, while the chapel of St George lay in ruins up to some point in the 19th century, when it was torn down in order to create space for the cemetery to the north of the church. ${ }^{20}$ During the medieval period the church probably had the form of a small single-aisled basilica, either wooden-roofed or covered with a barrel vault belonging to the type conventionally known as 'Heptanesian'.21 There is no further information about its architecture, form or decoration, since it was destroyed by Ottoman pirates in 1537, probably restored and then destroyed again in $1571 .^{22}$

As mentioned above, the church of the Virgin in Kassiopi was located very near to the port and was visible from the sea (Fig. 3). Many of the pilgrims who conveyed the legends and the miracles concerning the church saw it only from the ship and never actually disembarked. Even in circumstances of vows that had to be completed, it was not uncommon for the crew to send just one or

17 Count Alexander von Pfalz-Zweibrücken and Johann Ludwig von Nassau-Saarbrücken (1495-1496), '[...] die ganz zerbrochen ist durch einen Lindwurm oder Drachen, der da war in einem hohen Berg gegenüber der Stadt'. Karbach 1997, 55 .

18 Hans Werli (1483-1484): 'Denn für der Statt in dem Meer ist ein grosser Schroff und Felß. In dem ist gelegen ein grosser Trach der floge alle tage ob der Statt und bey der Statt herumb und bließ funcken von ihm und mit seinem feuwrigen Athem vergifftet er den Lufft daß die Leut in der Statt sturben [...].' Feyerabend 1584a, 185v. About the destruction of 1386, see Matton 1960, 73; Voyadjis and Raptaki 2007, 32.

19 Stamatopoulos 1993, 254; Landos 1896, 6.

20 Stamatopoulos 1993, 254; Landos 1896, 7.

21 Triantaphyllopoulos 1994, 32.

22 Asonitis 2009, 438-439; Bacci 2004b, 235; Karydis 1999, 297. 


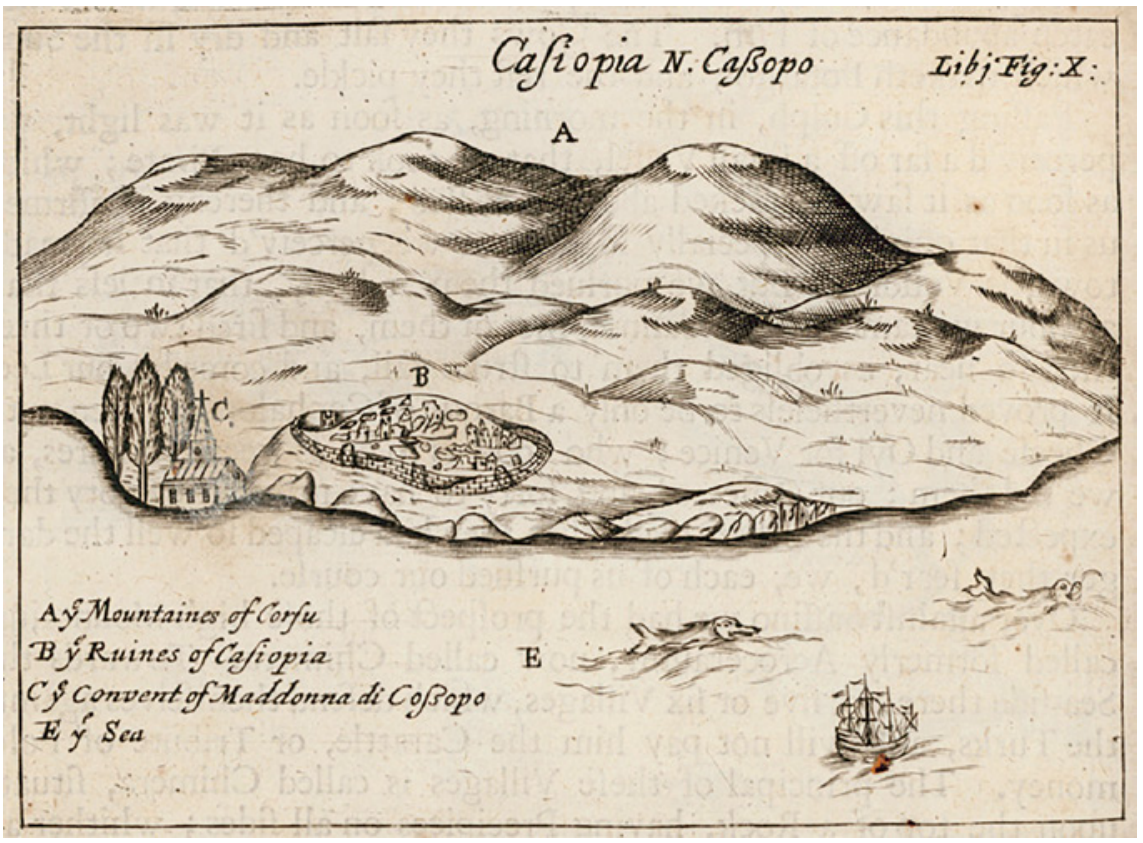

FIGURE 3 The church of the Virgin Kassopitra and the castle of Kassiopi, Corfu, 1682, engraving

a few pilgrims to make their offerings to the Virgin, as in the case of the ship carrying Alessandro di Filippo Rinuccini in 1474: as he recounts, when caught in a storm the pilgrims sent one of their group to prostrate to the Virgin at the church and then continued their journey. ${ }^{23}$

Even though many of the pilgrims simply reproduce narrations of the seafarers, because of the complete destruction and reconstruction of the church in the 16th century their reports remain the main source of information about it, its interior decoration and the cult practices associated with it. The quantity of pilgrims' references to the church of the Virgin is extremely high, especially when compared to those about the churches of the town of Corfu. As a matter of fact, the church of the Virgin Kassopitra is the site mentioned more times than any other within the area under consideration in this study. The site

23 ' [...] facemo jo pellegrino a mandare a Sancta Maria di Casopoli et andovi poi a comune spese il cappellano di nave ser Thommaso'. Calamai 1993, 85. An analogous experience is described by Santo Brasca (1480): 'Vedendo questo lo patrono fece che tuti inscieme votassemo de fare uno peregrino a Sancta Maria de Casoppo, et così facta la ricolta de li dinari, cum primum giongessimo in terra fu mandato via dicto peregrino.' Momigliano Lepschy 1966, 124 . 
was, to quote the late 15th-century pilgrim Pierre Barbatre, a 'place of devotion', while already in 1394 it was referred to as a renowned pilgrimage site. ${ }^{24}$ In his description of the island of Corfu in 1630, the Corfiot nobleman Stefanos Mastrakas mentions that besides the fact that there were two other anchorages to the north, as well as to the south of Kassiopi, '[...] because of the devotion to the church of the miraculous Virgin lying on that shore, all the warships and especially the galleys choose to visit it.'. ${ }^{25}$ Indeed, both commercial and pilgrim galleys, as well as warships, used to salute the Virgin with cannon fire when passing by the port. The French pilgrim Nicholas le Huen (1487) writes: '[...] there is an island that the Turks call Casapolis: that is the great house of heavens: there is the sacred dignified mother of Jesus, highly revered for her virtue, who is saluted with trumpets and cannon, and each one of us said their prayers.' ${ }^{26}$ The French merchant Antoine Regnault (1549) also describes the custom of saluting the Virgin as follows: 'Near Corfu, about six miles, we sailed before a church called Sancta Maria de Casopo. Our captain, along with all the gentlemen and officers kneeled, saluted the said church, while the bombardiers paid their respects with cannon shots, both when sailing towards Jerusalem and when sailing back.'27

Combining the descriptions of the pilgrims and travellers with the few surviving archival documents allows for an assessment of both the topographical setting, a factor that plays an important role in the experience of a pious religious visitor, and the mise-en-scène of the interior of the church. As mentioned above, the church was visible from passing ships and definitely recognisable by the seafarers. The area was uninhabited at least during the 14th century and the beginning of the $15^{\text {th }}$, so around the church there were no buildings, besides the one that housed the 'kalogeri' (Greek priests or monks), who appear already from 1413 to have been officiating and acting as caretakers of the increasingly famous church, obviously living off the revenues deriving

24 Pierre Barbatre (1480) characterises it as a liez de devotion, while Ogier viII d'Anglure (1395) describes it as a moult grant pelerinage. Pinzuti and Tucoo-Chala 1972-1973, 118; Bonnardot 1878,7 .

25 Tsitsas 1974, 72.

26 'Et entremy des deux y a une isle que les turcs nomment Casapolis: cest adire la grant maison du ciel: en laquelle fust la tres sacree digne mere a Jyjus anuncte de grant vertuz: \& fust saluee des trompettes \& des canons: et chescun de nous dist ses oroisons.' Huen 1488 , n.p.

27 'Au deca de Corfou enuiron six milles passames pres vne Chapelle appellée Sancta Maria de Casopo. Nostre patron, auee tous les Gentilhommes, \& officiers se misrent à genoux, saluant ladicte Chapelle, ensemble les Bombardiers, auec leur artillerie luy recommandant nostre naue, tant au aller, qu'à venir.' Regnault 1573, 19. 


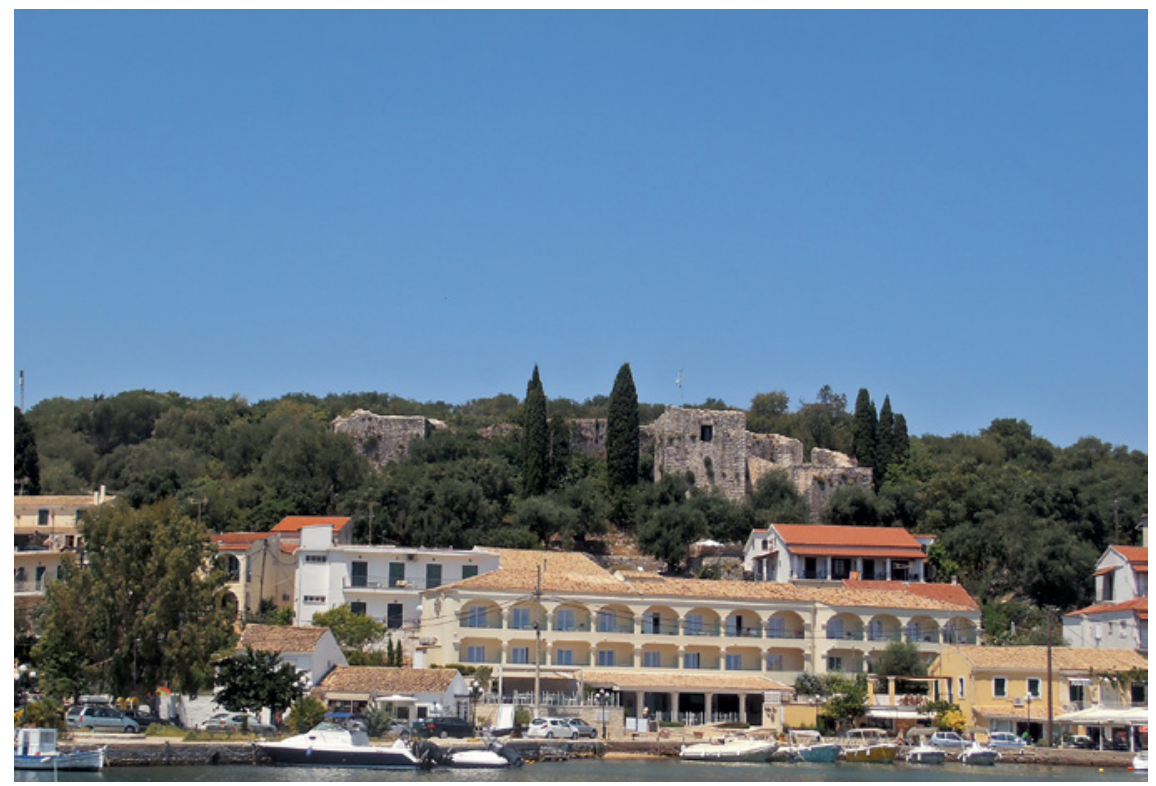

FIGURE 4 The castle of Kassiopi, Corfu, as seen from the port

from the donations of the pious visitors. ${ }^{28}$ The surrounding landscape was particularly imposing, since on top of the hill above the church stood the ruins of the castle that according to the legend was destroyed by a dragon (Fig. 4). ${ }^{29}$

28 Many pilgrims mention the abandoned, uninhabited town: Jacob Kreynck and Deryck Vogel (1479): ‘[...] een stad die volledig verwoest [...]'. Phillips 1982, 7. Jan Aerts (1481-1484): '[...] leydt een haven, met een verwoeste ende bedorve stadt, daer niemandt woonachtigh en is [...]'. Van Nispen 1652, 147. Pierre Mesenge [Charles de la Rivière] (1507): 'Et passasmes par devant une ville nommee cassopo, a present inhabitee [...]'. Pouge 1975, 27. Luchino del Campo was the first to mention 'uno calogiero che sta li', in 1413. Brandoli 2011, 43. In 1470 the German pilgrim Ulrich Brunner mentions again only one Greek priest living near the church. Röhricht 1906, 21. The number of priests or monks in Kassiopi rose after 1477, when Wilhelm Tzewers writes that 'Grecus circa capellam moratur sacerdos'; and from 1479-1480, when Hans Tucher visited the site, pilgrims begin to refer to ein pruderhau $\beta$, hinting that the number of priests or monks had risen significantly. Hartmann 2004, 98; Herz 2002, 357.

29 Almost all of the pilgrims mentioning Kassiopi refer to the ancient ruins on the hill above the church; Bernhard von Breydenbach (1483-1484): 'Ansonsten wohnt niemand in der genannten Stadt oder in ihrer Nähe, obwohl es hier noch unbeschädigte Mauern, Türme und Häuser gibt.' Mozer 2010, 91. Georges Lengherand of Mons (1485-1486): '[...] n'y a apparence que d'aucunnes viezes murailles [...]'. Ménilglaise 1861, 94. Felix Fabri (1480, 1483-1484): '[...] unde hodie stant muri civitatis, turris et domus, sed sine omni habitatore'. Hassler 1843-1849, vol. 3, 352. 
When disembarking, the pilgrims approached the 'beautiful Greek church', where the famous miraculous icon of the Virgin Kassopitra was kept. ${ }^{30}$ In front of the icon there was a perpetual lamp, which 'always burns and is full of oil, without ever being refilled', and there was at least one other lamp embedded in the back wall, as well as a tooth and a rib of the dragon that according to the legend destroyed the castle. ${ }^{31}$ According to another legend, also initially transmitted by the sailors and reproduced in almost all the travelogues, the oil of the lamp burning in front of the miraculous icon of the Virgin became a powerful medicine against fevers when a piece of the bark of a fig tree found outside the chapel was dipped in it, while it also offered protection from stormy weather, remedies of great importance for sea travellers. The French pilgrim Ogier VIII d'Anglure (1395) writes: 'In the church, in front of the icon, there is a lamp full of oil; and there is a fig tree in front of the church, whose wood, when dipped in the oil of this lamp, cures the fever. ${ }^{32}$

Until the destruction and reconstruction of the church in the 16th century, the pilgrims' site-related experience could be re-enacted as follows. Already from the galley, and obviously after hearing the narrations of the crew, the pilgrims saw a small church in the port, above which stood the ruins of an imposing castle. Approaching, as Hans Lochner (1435) attested, they could see from outside the light of the lamp that was burning in front of the icon. ${ }^{33}$ Going inside the church would have been a remarkable experience for Western pilgrims, since the small Greek/Orthodox church would have been adorned with frescoes and decorated and structured in a way completely different to what they would have been accustomed. ${ }^{34}$ The miraculous icon of the Virgin

$30 \quad$ Mariano da Siena (1431): ‘[... bella chiesa di greci [...]'. Pirillo 1991, 126.

31 Luchino del Campo (1413): '[...] la quale sempre arde e sempre sta piena di olio, nì mai se ne mette guzzo di olio'. Brandoli 2007, 43. The same information is also transmitted by among others: Wilhelm Tzewers, the anonymous author of Lo itinerario de andare in Hierusalem and Georges Lengherand of Mons. Hartmann 2004, 48; Longo 2007, 152; Ménilglaise 1861, 95; see also Bacci 2004b, 234.

32 'En laquelle chappelle, devant l'ymage, a une lampe plaine d'uille; et y a ung figuier devant ladite chappelle dont le bois, quand il est mouillés en l'uille d'icelle lampe, guarist de fievres.' Bonnardot 1878,7 . Most of the pilgrims who mention the church refer to the miraculous powers of the oil of the lamp.

33 'Von aussen sieht man ein kleines Lemplein, das Brenet ausswendig vorm Bild tag und nacht.' Geisheim 1858, 212.

34 The effect of the Greek-Byzantine churches to the eyes of a Western traveller is vividly expressed by the French pilgrim Nicolas Loupvent, in his description of Candia: 'Au reste se sont toutes esglises grecz, que sont en nombre plus de centz, mais ce nest pas grant chose a dire, voir au regart des esglises latines; mais a mon semblant, comme celuy qui a esté présent, ne sont point moin décorée tant en dévotion comme en cérémonie.' Bonnin 1976,56 . 
would have been surrounded by votive offerings. ${ }^{35}$ The veneration of the icon as described in the narratives was in keeping with Late Medieval practices of image worship: the pious visitors would offer candles, make donations, celebrate mass and of course make sure to take a piece of the fig tree bark dipped in the lamp oil with them. An anonymous Dutch pilgrim, who visited the church in the mid-14th century, attested to the habit of the pilgrims to take oil from the perpetual lamp with them, as well as pieces from the bark of the tree standing outside the chapel. ${ }^{36}$

The church of the Virgin Kassopitra was of juspatronato publico. That means it belonged to the local community and was under the jurisdiction of the Latin archbishopric. Despite the fact that it appears to have been an important pilgrimage site already from the 14th century, it was neglected by the Venetian ecclesiastical authorities, as attested by two documents of 1413 and 1423, when the local community complained that the building was in a very bad condition (pessimo stato), forcing the Venetian Senate to order its reconstruction using the money of the alms (elemosine) and other offerings to the church, which had been unlawfully kept by the archbishop. ${ }^{37}$ These documents, combined with the pilgrims' narratives about the priests living near the church, demonstrate that the Virgin Kassopitra must have had a notable income, enough to support one and later on more priests, as well as to cover the expenses of the restoration of the building. ${ }^{38}$ In addition, archival documents attest that already in 1414 a flea market took place at Kassiopi and it was in fact the largest one on the north side of the island. ${ }^{39}$ This may indicate that, at least during the first phases of the site's progression from a regional to an international place of worship, it was the local community actors who became aware of the change and made efforts to elevate it to suit the needs of Western pilgrims. A fascinating passage from the narration of the pilgrim Wilhelm Tzewers (1477-1478) reveals that the Greek priests who were officiating at the church, obviously responding to the increasing number of pilgrims visiting it, not only allowed them to carry out their liturgies in it, but actually provided a different chalice

35 About the references to the votive offerings, see Johann Markgrafen and Albrecht von Brandenburg-Ansbach [Hans Lochner]. Geisheim 1858; also Bacci 2004b, 235.

36 'Et omnes peregrini venientes ad hanc ecclesiam baculos in lampadem tingebant oleum sic haurientes. Nec ex hoc lampas defecit oleo cernitur enim lampas adhuc hodie. Item ibidem est eciam ficus quedam, cuius lignum optime valet contra febres.' Conrady $1882 \mathrm{~b}, 48$.

The documents are dated $3_{1}$ August 1413 and 30 March 1423 and both mention the poor condition of the building, as well as the fact that the income of the church was kept by the Latin archbishop. Fedalto 1978, 180; Sathas 188o-1883, vol. 1, 3 o.

38 About pilgrims' offerings to the church, see n. 23 above.

39 Asonitis 1999, 439; Sathas 1880-1883, vol. 1, 85. 
for the use of the Latins, so that the pious of both rites would be able to perform their mass while avoiding the use of the same liturgical vessels. ${ }^{40}$ Indeed, a number of pilgrims report celebrating mass inside the church of the Virgin. ${ }^{41}$

The church that the first pilgrims saw was destroyed in 1537 by the notorious Ottoman corsair and admiral Hayreddin Barbarossa and then again in the 1570 s by the Ottoman fleet, either during the siege of 1571 or the one of $1573 .{ }^{42}$ Two surviving traveller accounts, one after each of the destructions of the church, provide valuable information about the state of the building and hints of the whereabouts of the icon, which seems to have been either destroyed or relocated in the mid-16th century.

In 1537 Jean (Jehan) de la Vega, an eminent jurist from Marseille, travelled as a member of the French fleet, under the command of Bertrand d'Ornesan, Baron of Saint-Blancard, who collaborated with the Ottomans at the siege of Corfu as part of the alliance of Francis I with Sultan Suleiman the Magnificent. ${ }^{43}$ De la Vega was appointed by the French king to write the narration of the expedition, during which the church of the Virgin Kassopitra was destroyed. ${ }^{44}$ He visited Kassiopi right after the passing of the Ottoman fleet and attested to the almost complete destruction of the church:

The 13th day of September, the baron, along with the whole army, went to prostrate at the extremity of the said island of Corfu, at the Virgin of Casoppe, but we found the church destroyed, without a roof, filled with animal excrement, the monastery looted and ruined and two or three corpses in front of it that smelled awful.

However, we entered the church, the paintings [icons?] were all disgracefully covered with filth, except the icon of the Virgin that was to the right of the vault of the altar, from which a Turk tried to detach a small silver icon that according to the local custom the pilgrims offer and attach

40 'Grecus circa capellam moratur sacerdos, qui habet calicem pro se et pro Latinis. Putant violatum suum, si nos cum eo communicamus.' Hartmann 2004, 98.

41 Luchino del Campo, recording the journey of the Italian marquis Nicolo d'Este (1413), attests: 'E smontato il Signore in terra, fece celebrare la messa nella chiesia di Nostra Donna [...].' Brandoli 2011, 43. The pilgrims Count Alexander von Pfalz-Zweibrücken and Johann Ludwig von Nassau-Saarbrücken (1495-1496): ‘[...] der meiste Teil der Pilgrim ans Land gefahren zu einer Kirche, da unsere liebe Frau fast gnädig ist, genannt St. Maria de Gasapo, da Messe gehört und das Opfer, davon ich vor geschrieben habe, getragen'. Karbach 1997, 99. Francesco Grassetto da Lonigo (1511), ‘[...] et a l'aurora zongem a santa Maria de Casopo, et quivi fu cantata una messa [...]'. Ceruti 1886, 14.

42 Giotopoulou-Sisilianou 1997, 67-70.

43 Garnier 2008, 127-145.

44 Garnier 2008, 134. The work of Jehan de la Vega was published after 1538 under the title Le voyage du Baron de Saint Blancard en Turquie l'an 1537. 
to the said icon, when suddenly he lost his sight, and because of that no other Turk dared to touch or profane the said icon, in front of which the baron placed an altar table and performed a mass $[\ldots]^{45}$

Much important information can be drawn from the jurist's narration. It seems clear that the French were aware of the fame of the Virgin of Kassiopi and they decided to visit it. The extent of the destruction of the church is vividly described and, most importantly, it is clearly stated that the icon of the Virgin was not damaged because of divine intervention. The narration also provides information about the cultic practices of the pilgrims in regard to the site, that is, the placement of votive offerings, such as small silver icons, 'according to the local custom. ${ }^{46}$ Finally, before leaving the site, the French troops performed a Latin mass in front of the icon, inside the Orthodox chapel their Ottoman allies had destroyed.

In 1579, after the second destruction of the church by the Ottoman fleet, the French pilgrim Carlier de Pinon gave details about the site. He mentions the previous destruction by Barbarossa, while he describes: 'Below the said mountain, on the seaside, there is a small church, called Madonna di Casopo, which is very renowned, even though it lies in ruins. ${ }^{47}$ It is clear from the excerpt that Carlier de Pinon was also aware of the fame of the church and seems to be surprised by the fact that such an important pilgrimage site was lying in ruins. In his narration he makes no mention of the icon, while he affirms the habit of the seafarers to salute the Virgin with cannon fire. ${ }^{48}$

The destruction of 1537 is, as expected, reflected in pilgrims' narratives: in 1542 Jodocus von Meggen refers to the destruction by the Ottomans, but also reports seeing the church standing and the lamp inside it, adding that it

45 The full text reads: 'Le xme jour de septembre le dict baron et toute larmee alasmes au coing de la dicte isle de Corfou a une devotion de Nostre-Dame de Casoppe, trouvasmes l'eglise detruicte descouverte plaine dimmundices des entrailles de bestial, le couvent rompu et desfaict, deux ou trois corps morts la au devant que tout donnoit grande puanteur. Ce nonobstant entrasmes dans leglise, les ymages estoient tous vituperez dimmundice et ordue, fors limage notre dame qui estoit au coste dextre de la voulte de lautel, auquel un Turc voulut arracher ung petit image dargent, que selon les coustumes du pays les pelerins y apportent, et font afficer au dict image, subitement devint aveugle qui fut cause que nul autre Turcs ossat toucher ne oultraiger le dict ymaige, devant lequel le baron fect dresser une table pour autel et chanter une messe [...].' Foucault 1868, 477.

$46 \quad$ See $n .45$ above.

47 'Au bas de ladicte Montaigne sur le bord de la mere est une petite esglise, nommee Madonna di Casopo, qui est fort renommee, encores qu'il n'y ait rien que ruines.' Blochet 1920, 40.

48 'Le 19, ayants faict voile, noz mariniers tirent quelques coups de cannon en l'honneur de Madonna di Casopo.' Blochet 1920, 40. 
still 'attracts attention' ${ }^{49}$ Five years later, another pilgrim, the French Antoine Regnault, mentions the destruction of 1537 , but he also saw the church and describes in detail the custom of the mariners' salute to the Virgin. ${ }^{50}$ While it is clear from eye-witness testimonies that the church of the Virgin Kassopitra was severely damaged, if not destroyed, in 1537 as well as in the 1570 , in the interim it must have been restored and was still functioning, since, besides the aforementioned travelogues, archival documents attest that in 1554 there was a hieromonk performing services there. ${ }^{51}$

Following its second destruction, the church was rebuilt on a smaller scale by the Venetian Commander of the Triremes, Pietro Francesco Malipiero. Later on, it was enlarged by the Commander of the Adriatic Sea, Filippo Pasqualigo, and in 1590 by the Proveditor of the Fleet, Admiral Francesco Suriano, as indicated by an inscription on a marble plaque embedded on the wall above the entrance (Figs $5 \mathrm{a}, 5 \mathrm{~b}$ ). ${ }^{52}$ Based on architectural elements of the new building (in particular two side altars and the apses of another four), some scholars support that after the last restoration the church was converted into a Roman Catholic building..$^{53}$ Besides the fact that such features should not necessarily appear out of place in a late 16th-century Greek rite church, one should consider the very strict Venetian religious policy regarding Orthodox churches, plus the indubitable reaction an act such as that would provoke in the Greek clergy and flock, which would definitely be recorded in archival documents of the period. A travelogue from 1600 corroborates the fact that the church of the Virgin remained Orthodox, as only ten years after its renovation the pilgrim Henry Castela stated that the church was officiated by 'Caloyers' (Greek monks). ${ }^{54}$

The fact that the Ottoman fleet devoted time and effort in order to destroy a small church located at a place of no specific military advantage is quite

49 'Ibi quodes inter eundum vidimus oppidum dictum Casopum, vbi praeter oppidi moenia nil fererelictum à Turcis est. Habet et templum D. virgini sacrum, ubi semper lumen ardens, illis oleum suppeditantibus, conspici aiunt.' Von Meggen 1580, 49.

50 About the salute to the Virgin, see n. 27 above. Concerning the destruction of the church, Antoine Regnault writes: 'Le patron \& officiers nous dirent, qu'autres fois l'armée du Turc fit descente en a ville, \& isle dudicte Corfou, bruslerent, \& saccagerent tout, resté le Chasteau \& ladicte Chapelle.' Regnault 1573, 19.

$51 \quad$ Karydis 1999, 297.

52 Bacci 2004b, 235; Stamatopoulos 1993, 254-255; Tsitsas 1968, 2-3. The inscription was published in Rusconi 1952, 461 .

53 Tsitsas 1968, 5; Stamatopoulos 1993, 254. About the debate on the conviction that Greek churches were always served by one single altar and the hypothesis that additional aisles, apses and altars within Greek churches attest to its use by Latins and Greeks, see Olympios 2013, 326-328, esp. 327 and nn. 21-22.

'[...] est seruie par des Caloyers Grecs [...]'. Castela 1603, 49o. 


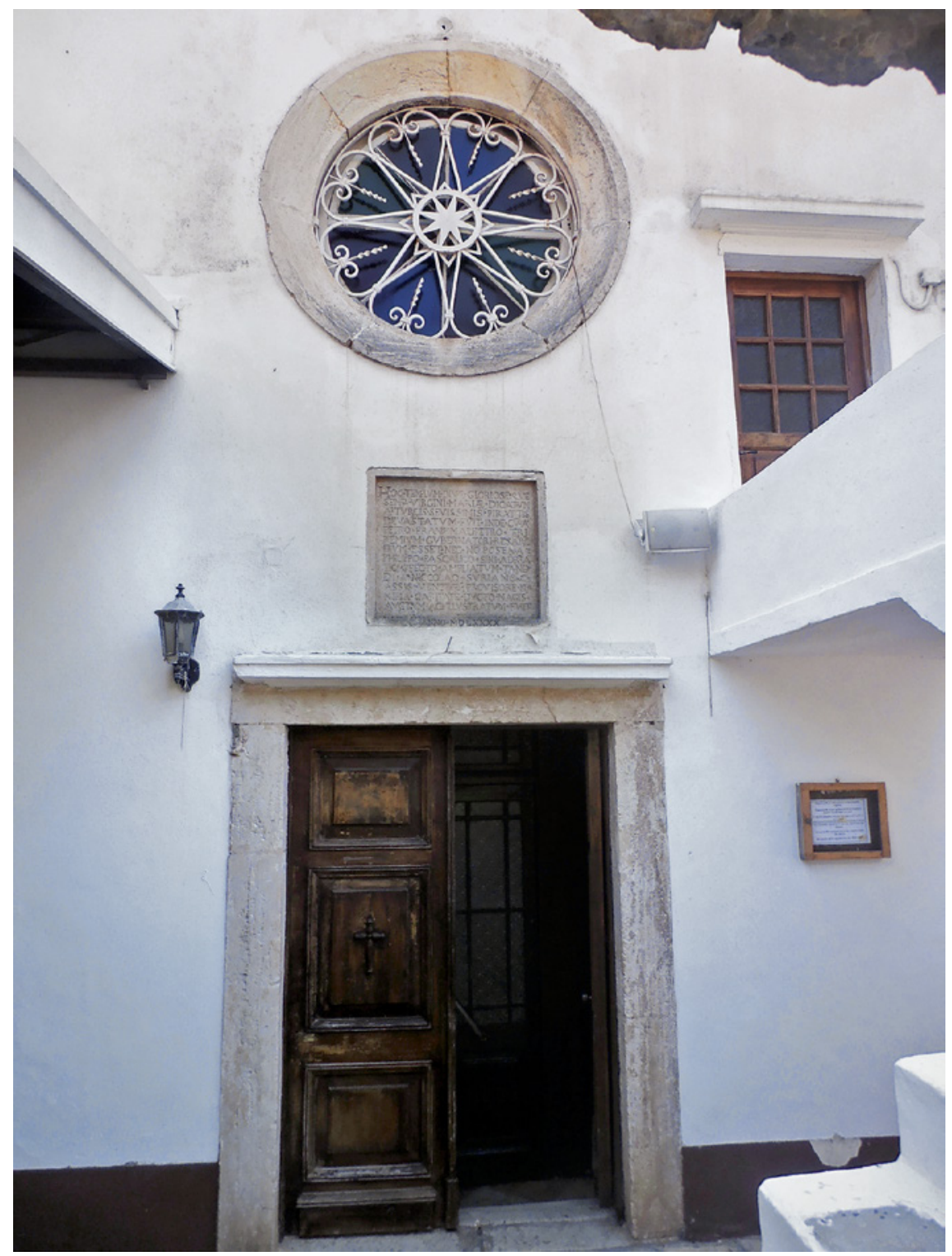

FIGURE 5a The church of the Virgin Kassopitra, Corfu, west entrance

peculiar and could be interpreted as an attestation of the fame of the church of the Virgin Kassopitra and its importance as a maritime shrine. ${ }^{55}$ At this

55 M. Bacci, Center for Early Medieval Studies [www Document], 2017. YouTube. https:// www.youtube.com/watch?v=C7Bzygv_Cwc (accessed 28 April 2021). 


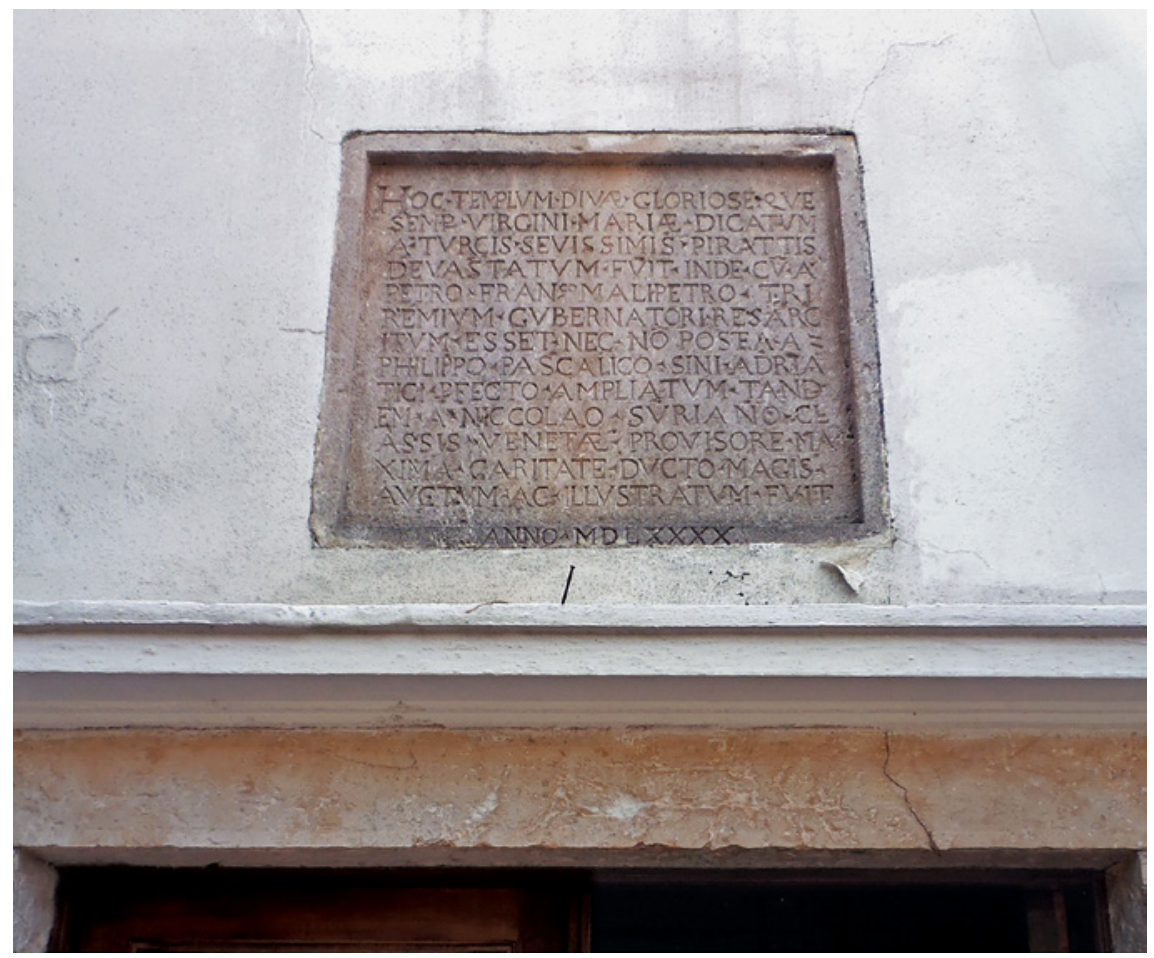

FIGURE 5b The inscription of 1590 at the church of the Virgin Kassopitra, Corfu, with the names of the church's Venetian renovators

point, it needs to be stressed that, while the tactical importance of the port of Kassiopi is undeniable, the area did not have a specific military function, and, in any case, its significance as a maritime shrine went hand in hand with its strategic position. So, when the Ottoman fleet was tearing down the church of the Virgin, they most probably believed that in this way they were depriving Corfu and the Venetian fleet of its divine protection. The restoration of an Orthodox church by Venetian officials could be considered equally strange. A reason for that could be the international fame it acquired over time, but, taking it one step further and considering the fact that all three of the aforementioned officials were occupying offices directly related to the sea and the fleet, their action could be seen as underlining the significance of the site for seafarers.

While reading the above, one should bear in mind that Corfu had been an extremely important acquisition for the political, military and commercial interests of Venice. It is because of its strategic geographical location that 
Corfu has been the bone of contention between rivalling powers throughout its history and from the 16th century onwards under the constant threat of the Ottomans. Being an island, its main defenders were the sailors of the Venetian fleet, who for centuries had a close connection to the Virgin of Kassiopi. So, the attention given to the church by the Venetian officials served not only the needs and desires of the pilgrims, but was also an expression of their deep respect, faith and devotion to their protectress.

The importance of this maritime shrine for the members of the Venetian fleet is clearly attested in the events of the naval battle of Kassiopi in 1716 that led to the lifting of the siege of Corfu and the end of the seventh OttomanVenetian War. On the evening of Wednesday, 8 July 1716, the Venetian flagship, under the command of Andrea Corner, was sailing through the straits to join the rest of the fleet, under the command of Andrea Pisani, in order to combine forces and prepare for the upcoming battle. It was then that the flagship Madonna della Salute passed right in front of the church of Kassopitra and fired three cannon shots to salute the Virgin, according to the custom, followed by all the ships sailing behind it. The cannon, which were heard all the way to the town of Corfu, did of course give away their position to the enemy and led to a battle, depriving the Venetian fleet of valuable time to sail through the straits and deploy. Written testimonies of the period attest to this: 'The first cannon shots were fired in honour of the Holy Church of the Blessed Virgin of Kassiopi to presage the battle and the defeat of the enemy. ${ }^{56}$ Andrea Corner himself was later on accused of recklessness and apologised in writing to the doge.${ }^{57}$ Corner's decision to pay respects to the Virgin is indicative of the power of the cult upon the mariners. It would be impossible for the appointed commander of the flagship not to understand that this action was completely against common sense, but, on the other hand, he probably feared that, if he did not comply with the custom, he would be accused for that in case of a defeat. Besides being a clear corroboration of the cult's persistence up to the 18th century, this action makes the Ottomans' decision to destroy the church of the Virgin back in the 16th century more understandable, since it renders obvious that the Venetians actually did consider the Virgin Kassopitra to be their protectress in battle.

\footnotetext{
56 Excerpt from the manuscript of an anonymous Italian, under the title Relazione, o sia trattato di quanto e successo tra l'Armi Venete, e l'Ottomane l'anno 1716, located in the Biblioteca Marciana of Venice and published in Athanasainas 2001, 151. 
The restoration of 1590 was the last major intervention to the church building. At some point towards the end of the 17 th century, the wooden roof was replaced by a lower barrel vault, and a few minor modifications were made, leading to its present form. ${ }^{58}$ At the beginning of the 19th century it came under the jurisdiction of the Greek state and the municipality of Kassiopi. In 1842 it was looted once again and was abandoned for at least two years. ${ }^{59}$ Today, priests appointed by the Archbishopric of Corfu officiate there on a regular basis, while the monument is open to visitors and, even though it does not enjoy its former fame, still attracts attention (Figs 6a, 6b).

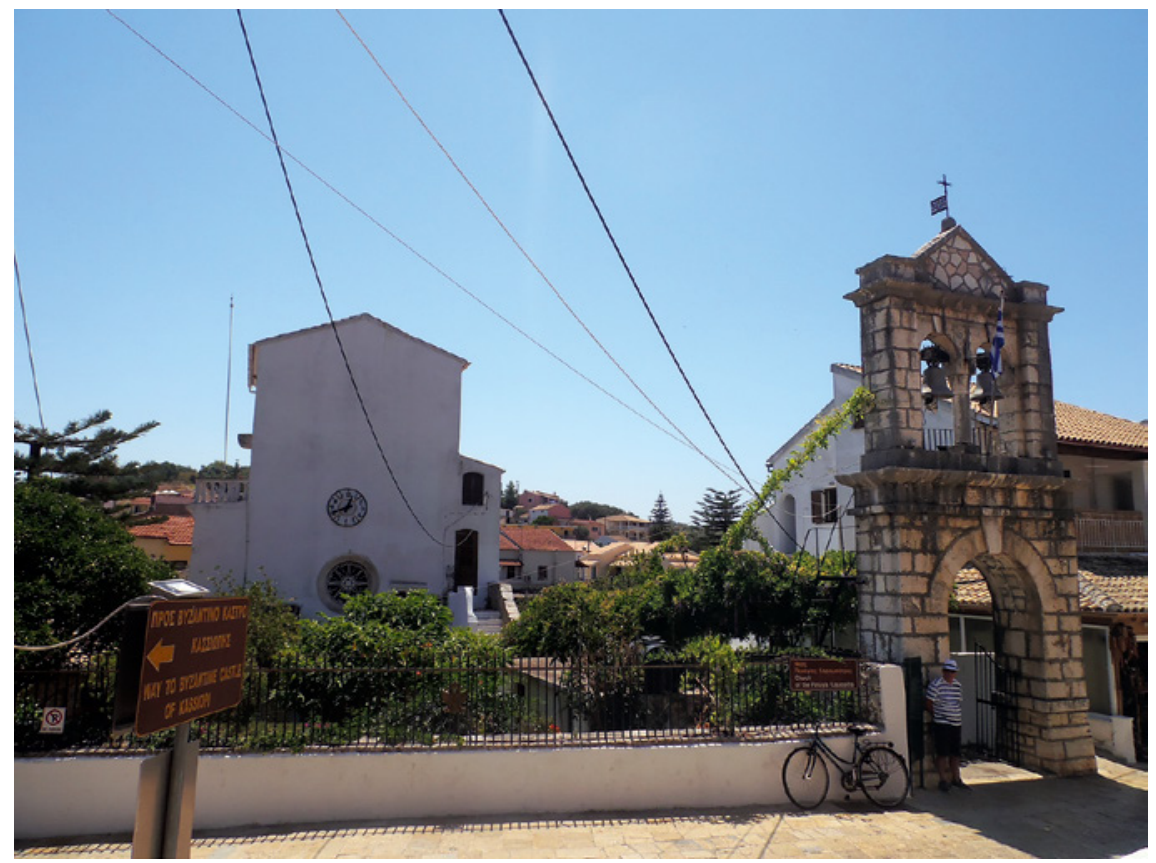

FIGURE 6a The church of the Virgin Kassopitra, Corfu, view from the west

$5^{8}$ Triantaphylopoullos 1980, 65o. Fragments of the 17th-century decoration survive inside the church. St Nicholas and an archangel are depicted on the south wall and the Virgin Mary and St Panteleimon on the north. The iconostasis is built on masonry, but bears no icons of distinction. During conservation works fragments of frescoes dated to earlier periods (probably to the 14th century) came to light, attesting to the fact that the restoration of 1590 incorporated parts of the medieval church. Stone arches of a previous building phase survive on the south wall, as well as some architectural parts scattered in the forecourt. Stamatopoulos 1993, 255; Triantaphylopoullos 1980, 65o; 21st Byzantine Ephorate, Corfu.

Landos 1896, 19 . 


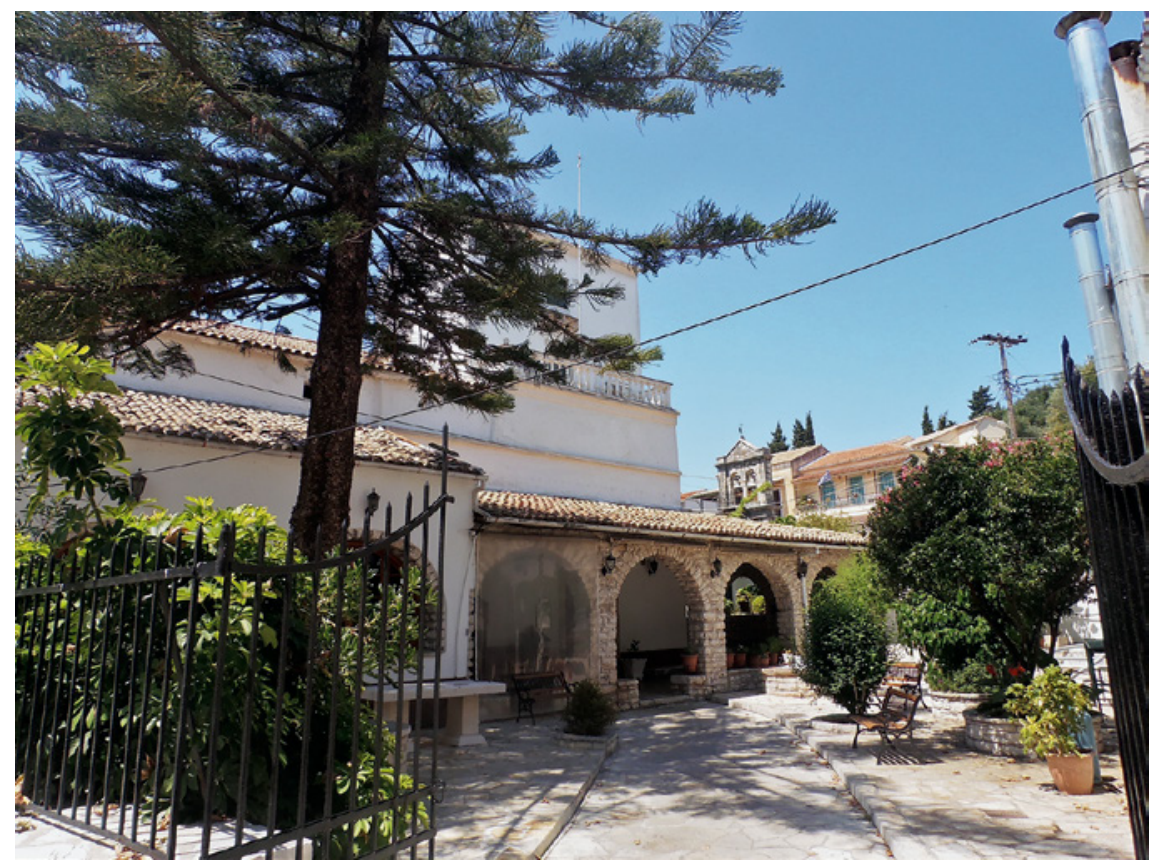

FIGURE $6 \mathrm{~b}$ The church of the Virgin Kassopitra, Corfu, view from the north

\subsubsection{The Icon of the Virgin Kassopitra}

The sacred and most venerated effigy of the church of Kassiopi was the miraculous icon of the Virgin, known as the Panagia Kassopitra, in front of which the perpetual lamp burnt. Since it was housed and worshipped in an Orthodox church of the Early Christian period and later on was attributed to the Evangelist Luke, it would be plausible to deduce that the icon was painted in the Byzantine style and was probably of Byzantine origin.

A substantial number of pilgrims mention the icon, but there is also a large portion of them that make no reference to it. ${ }^{60}$ It is not an uncommon phenomenon for seafarers and travellers to evoke a site instead of a specific icon, relic or saint. Likewise, icons do not necessarily have to be the pilgrims' goal,

6o This phenomenon of pilgrims not referring to an otherwise highly venerated icon at Marian cult sites they visit on their way to the Holy Land within the area of this study is not limited to the case of Kassiopi. Actually, the icon of the Virgin Kassopitra is the one that amasses the largest number of references, when compared to the famous icon of the Virgin Thalassomachousa of the Strophades monastery, which is not directly mentioned, or the palladium of the city of Candia, the icon of the Virgin Mesopanditissa, both attributed to the hand of the Evangelist Luke. 
and this does not in any case diminish their value, since they are still the 'material concretion' of the sanctity attributed to a place. ${ }^{61}$

The first to mention the miraculous icon of the Virgin Kassopitra is the Italian notary Nicola de Martoni, who visited Kassiopi in 1395: 'There is an image of the highly venerated blessed Virgin that every day performs miracles. ${ }^{62}$ Thereafter many pilgrims refer to it, although without providing a description. So the style, type and form of the icon, as well as its exact location in the church, cannot be determined with certainty. The French traveller Jean de la Vega, who disembarked at the small port after the Ottoman siege in 1537, stated that the icon was located at the time 'to the right of the vault of the altar'.63 Being the only surviving attestation of the icon's location, in a church whose size and architectural type is also unknown, de la Vega's rather vague description offers only hints of its position. According to him, the icon could have been placed inside the apse, to the right above the altar table, or on the wall right next to the vault of the altar. Given that the church was probably a single-nave building, would that mean that it was placed on the north wall or was there an altar screen where the icon was placed to the right of the central opening? Whatever the case, the icon has an uninterrupted presence in pilgrims' travelogues until the end of the $15^{\text {th }}$ century.

At some point during the $15^{\text {th }}$ century the venerated icon of the Virgin was attributed to the Evangelist Luke. Following this attribution, the perception of the site was elevated, mainly from the pilgrims' point of view, since it acquired apostolic connotations. The tendency of investing the ports of call with cultic meanings and attractions which anticipated the religious experience pilgrims were expecting to have in Jerusalem was a common phenomenon concerning the whole maritime route to the Holy Land. Travellers sought and, in this case, were actually given the opportunity to evoke the cultic attractions they expected to see in Jerusalem in a synecdochical way with the venerated Marian icon that was deemed to be an authentic portrait of the Virgin painted by Luke. ${ }^{64}$ Thus, the cultic object, besides being the sanctifying actor of the site, translates in a way a portion of the materiality of the Holy Land to the small port of Kassiopi. ${ }^{65}$

61 Carr 2000, 327. The notion, as well as the expression of icons being the 'material concretion' of sanctity, was introduced by Gerhard Wolf. See Wolf 2000.

62 The text reads: 'Est ibi quedam figura beate Marie Virginis devota multum que omni die facit miracula.' Piccirillo 2003,164 .

63 See n. 45 above.

64 About Lucan icons, see Bacci 1998, Bacci 2004a.

65 M. Bacci: Center for Early Medieval Studies [www Document], 2017. YouTube. https:// www.youtube.com/watch?v=C7Bzygv_Cwc (accessed 28 April 2021). 
Oddly enough, the attribution of the icon to the hand of Luke is mentioned by just one pilgrim and survives only in oral tradition. Nevertheless, this was the factor that attached apostolic connotations to the icon and allowed its elevation on the already existing network of Marian cult sites on the route to Jerusalem. ${ }^{66}$ In this context, the attribution to Luke allowed it to be perceived as one of the evangelic memorials that pilgrims were eager to approach. ${ }^{67}$ The questions that arise from this are: who were the actors that propagated this attribution to the Evangelist and what needs or desires did they intend to meet?

The obvious assumption would be that the attribution to Luke was a response to a need of the pilgrims, who sought objects or relics that could link them with their final destination, rather than to a need of the local population, since, despite the fact that the legend of its attribution to Luke was certainly circulating around the island already in 1530, the image is not referred to as a Lucan icon by local chroniclers of the time. On the other hand, given that already from the 15th century St Spyridon's relic has been translated to Corfu and his cult was rapidly growing, an elevation of the cult of the Virgin could only benefit the church and the community of Kassiopi. While this question remains to be answered, what could be quite safely assumed is that both locals and pilgrims would desire, in different ways and for different purposes, a miraculous Lucan icon, and the community of Kassiopi would definitely benefit from its presence.

As far as the actual effigy is concerned, Athanasios Tsitsas, who thoroughly studied the churches of Corfu, presented two hypotheses. In his first assertion, he goes as far as to hint that the miraculous icon did not exist, a supposition that had been proposed by Michael Landos in $1896 .{ }^{68}$ According to it, the venerated Virgin Kassopitra was a fresco, like the ones commonly adorning Byzantine churches, which during the 16th century was replaced with the one existing today. ${ }^{69}$ Despite the lack of solid material evidence that could disprove it, this hypothesis does not seem probable, since it goes against the popular notion of miraculous icons, deeply rooted in the Greek Orthodox mentality and widespread throughout the area of this study. ${ }^{70}$ In addition, as attested by the German pilgrim Wilhelm Tzewers (1477-1478), the icon had already been attributed to the Evangelist Luke at the end of the $15^{\text {th }}$ century, something that

66 See $n .5$ above.

67 Bacci $2012,148$.

68 Landos 1896, 8.

69 Tsitsas 1968, 6.

70 Lidov 2000, 47-57. About the Marian cult sites and the miraculous icons of the Virgin along the sea route from Venice to the Holy Land, see Bacci et al. 2017. 
would not be possible in the case of a fresco: 'Near Corfu, around 20 miles, there is a church dedicated to the Blessed Virgin. They call it Caseopolis. It is miracle-working. They say that the icon was made by Luke, and there is also a lamp that is refilled with oil only four times a year, but always burns. ${ }^{71}$ Pilgrims' testimonies could be used to support the existence of an icon, but since they often use the same words to describe icons, frescoes or even statues, this cannot be evaluated with certainty. ${ }^{72}$

According to Athanasios Tsitsas's second hypothesis, also supported by other scholars, the icon did exist, but was either destroyed and replaced, probably in the 16th century, or removed from the church in order to be protected from pirate and Ottoman raids after the destruction of $1537 .{ }^{73}$ If one accepts this assertion and consequently the existence of the miraculous icon, it could plausibly be assumed that the 16th-century fresco in the nave of the church reproduces the actual cultic object (Fig. 7). ${ }^{74}$ Iconographic similarities to this fresco can also be traced in the enthroned Virgin depicted in the icon given as an ex-voto by the famous Cretan painter Theodoros Poulakis in 1670 and dedicated to the church in memory of his salvation from a shipwreck (Figs 8a, $8 \mathrm{~b}$ ), as well as a second votive icon of Eustathios Kouvaras, probably a mariner who survived a naval battle, dating from the 17 th century (Fig. 9). ${ }^{75}$ If this is the case, the original icon could be replicated as depicting the Virgin Mary in a frontal position, perhaps enthroned, holding the Christ Child, who is administering a blessing. As mentioned, the oldest reference to this icon dates back to 1394, providing a terminus ante quem for its dating (that is, the last decade of the 14th century). As indicated by Michele Bacci and assuming that the 16th-century fresco reproduces the original effigy, the icon the first pilgrims saw in the church bears significant resemblance to the palladium of Venice, the Byzantine icon of the Virgin Nicopeia. ${ }^{76}$ This means that even though the architecture, setting, decoration or devotional practices followed at the church

71 'Circa Curfum ad xx miliaria est capella beate virginis. Dicitur Caseopolis. Claret multis miraculis. Dicunt beatum Lucam imaginem fecisse et esse ibi lampadem, que non impletur oleo, nisi quater in anno, semper tamen ardens.' Hartmann 2004, 98.

72 Ogier VIII d'Anglure uses the word ymage, Ulrich Brunner the word bilde and Nicola de Martoni, Michele da Figline and Paul Walther Guglingen the word immagine, while the Italian pilgrims Luchino del Campo, Mariano da Siena and the anonymous author of $L o$ itinerario de andare in Hierusalem use the word figura. Bonnardot 1878, 7; Röhricht 1906, 21; Brandoli 2011, 43; Piccirillo 2003, 165; Montesano 2010, 58; Sollweck 1892, 77; Pirillo 1991, 126; Longo 2007, 152 .

73 Stamatopoulos 1993, 256; Bacci 2012, 185; Landos 1896, 8; Tsitsas 1968, 6.

74 Bacci 2012, 185.

75 Vokotopoulos 199o, 127-128, pls 239-240, 155, pl. 294; Stamatopoulos 1993, 255.

$76 \quad$ Bacci 2012, 185 . 


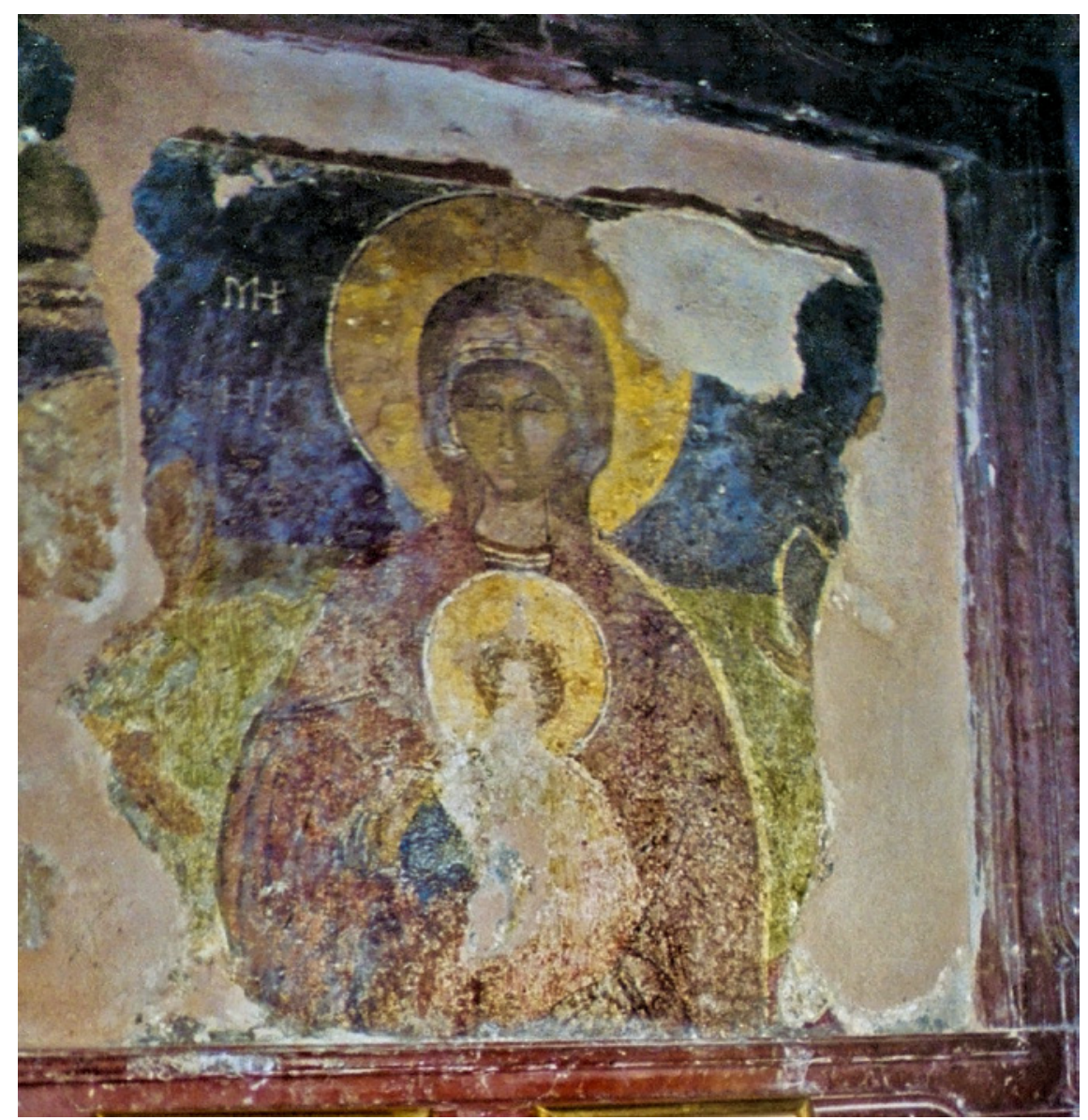

FIGURE 7 The Virgin Kassopitra in the church of the Virgin Kassopitra, Corfu, late 16th century, fresco

of the Virgin in Kassiopi might have been alien to a Western Catholic, the type of icon was familiar to them, since they would have seen the highly venerated icon of the Virgin Nicopeia in the basilica of San Marco in Venice (Fig. 10). ${ }^{77}$

The fame of the icon of the Virgin Kassopitra was enhanced even further during the decade of the 1530s, when it was associated with the miraculous

77 Westerners regularly criticised certain Orthodox customs, but they always acknowledged the cultic worthiness of churches and even of the liturgy. To get an idea of the way in which Western pilgrims perceived the Orthodox, it is interesting to cite the words of Greffin Affagart: '[...] et y demeurent des religieux grecs de Sainct-Basille; ilz les appellent Caloys, fort dévotz, mais toutesfoiz ilz sont scismatiques, séparéz de l'église roumaine, et aussi tous les grecs.' Chavanon 1902, 31 . 


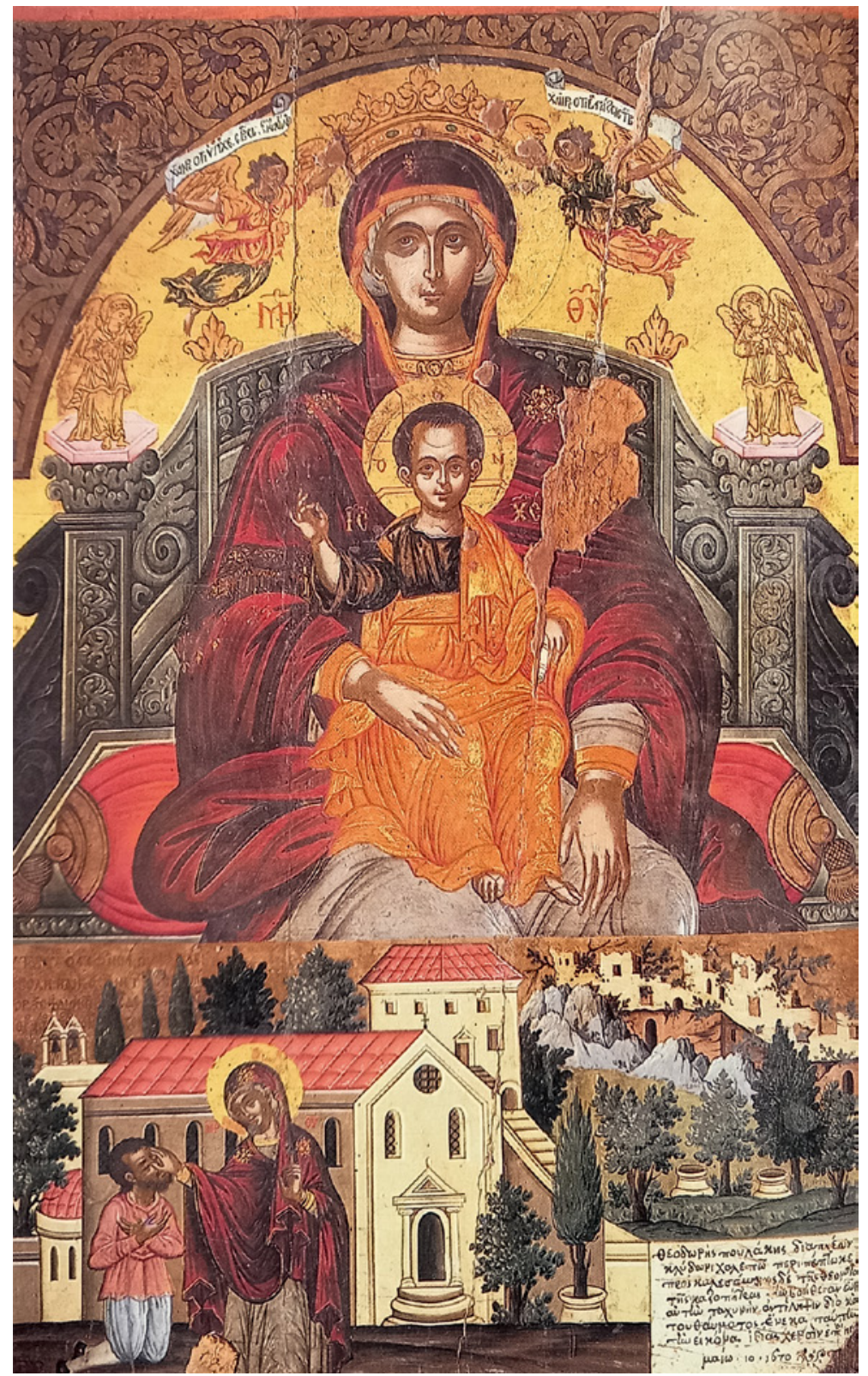

FIGURE 8a Theodoros Poulakis, votive icon of the Virgin Kassopitra, 1670 


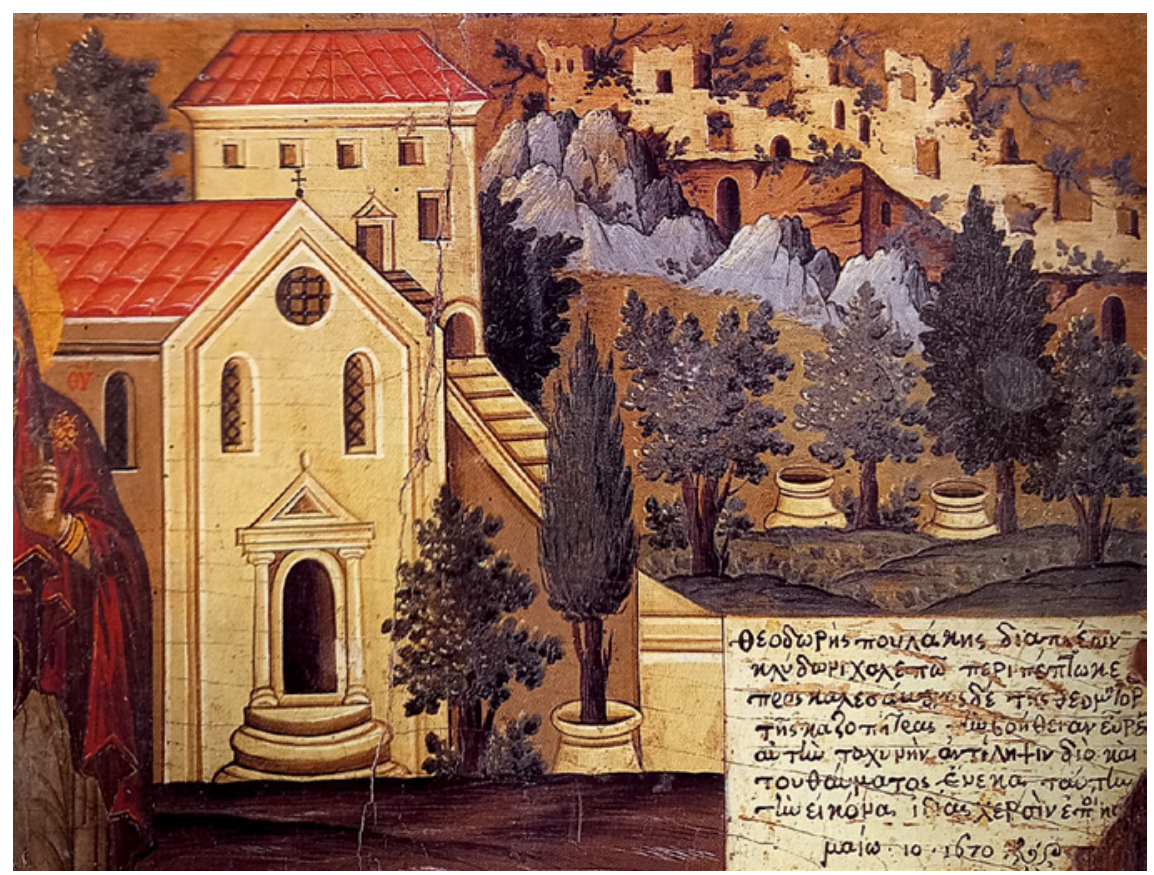

FIGURE 8b The church of the Virgin Kassopitra and the castle of Kassiopi. Detail of Fig. 8a

healing of Stefanos, a young Greek peasant falsely accused and sentenced to have his eyes put out. ${ }^{78}$ The news of the divine intervention of the Virgin spread very quickly around the island, as well as to the neighbouring coasts of Epirus and Albania, leading to the foundation of several churches dedicated to the Virgin Kassopitra. ${ }^{79}$ The extent of the diffusion and effect of the miracle

78 According to the narration of the miracle, Stefanos was falsely accused of stealing and was sentenced by the bailiff of Corfu to have his eyes put out. After the public implementation of the punishment and because of the general condemnation, his mother decided to move him away from the town and took him to the church of the Virgin in Kassiopi. Having asked permission from the monk, Stefanos and his mother slept inside the church, under the miraculous icon, where the young man had a vision of the Virgin and regained his sight. The next day, when the monk saw the result of the miracle, he rushed to the town of Corfu and announced it to the bailiff, who visited the church in person in order to verify the healing and to bow down before the miraculous icon. Stamatopoulos 1978, 256; Landos 1896, 8-17; Mustoxidis 1865, 15; Tsitsas 1968, 8-10.

79 A number of churches dedicated to the Virgin Kassopitra were founded from the 16th century onwards, among which the convent at Stratia and the church at Chlomotiana on Corfu, as well as the church of the Virgin Kassopitra at Arta. Tsitsas 1968, 8; Papageorgiou $1920,236$. 


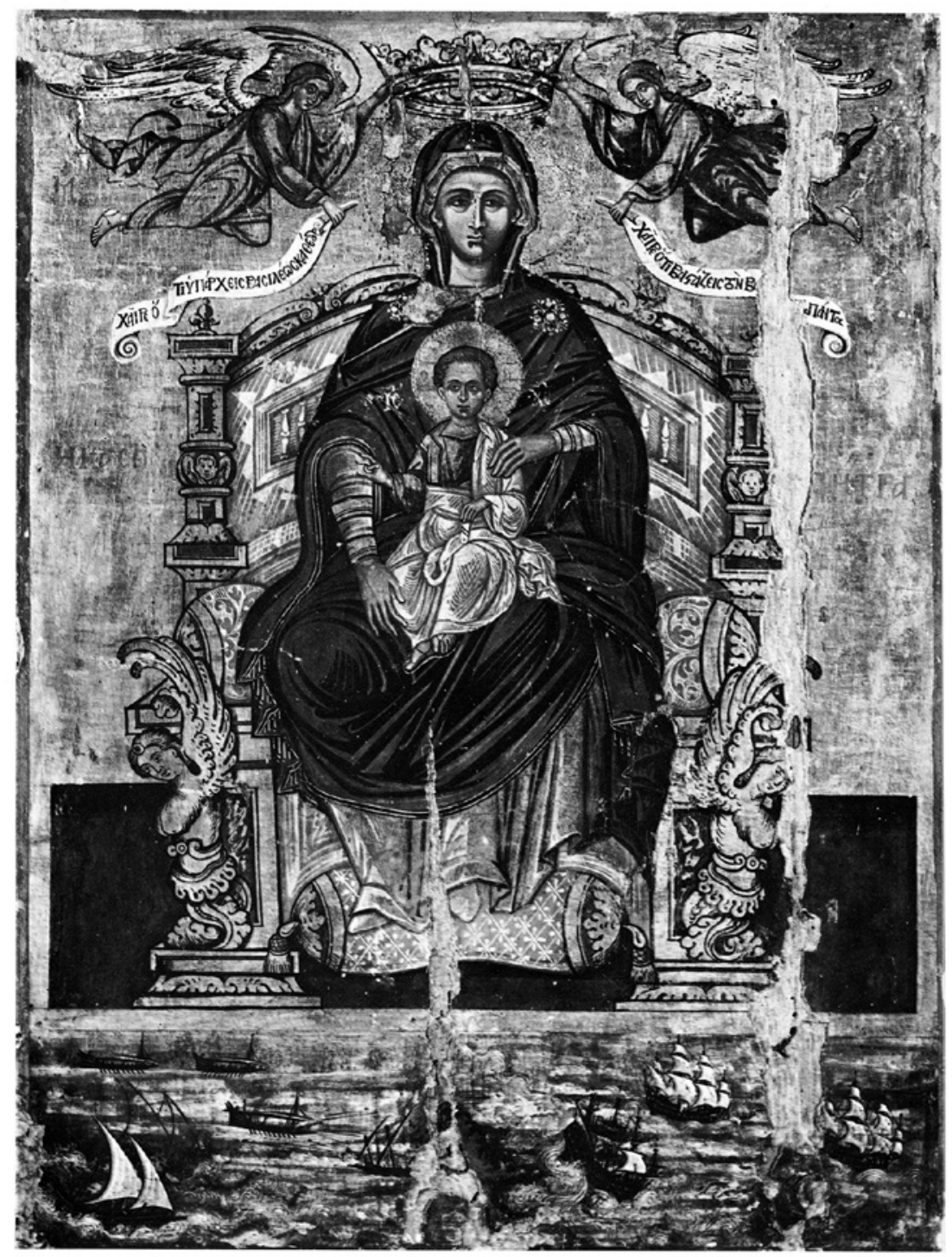

FIGURE 9 Eustathios Kouvaras, votive icon of the Virgin Kassopitra, 17th century

is reflected in the votive icon of Theodoros Poulakis, who chose to depict the healing of blind Stefanos instead of his own salvation, in memory of which he dedicated the icon to the church. ${ }^{80}$ The miracle performed by the Virgin in

8o Vokotopoulos 1990, 127-128, pls 239-240. 


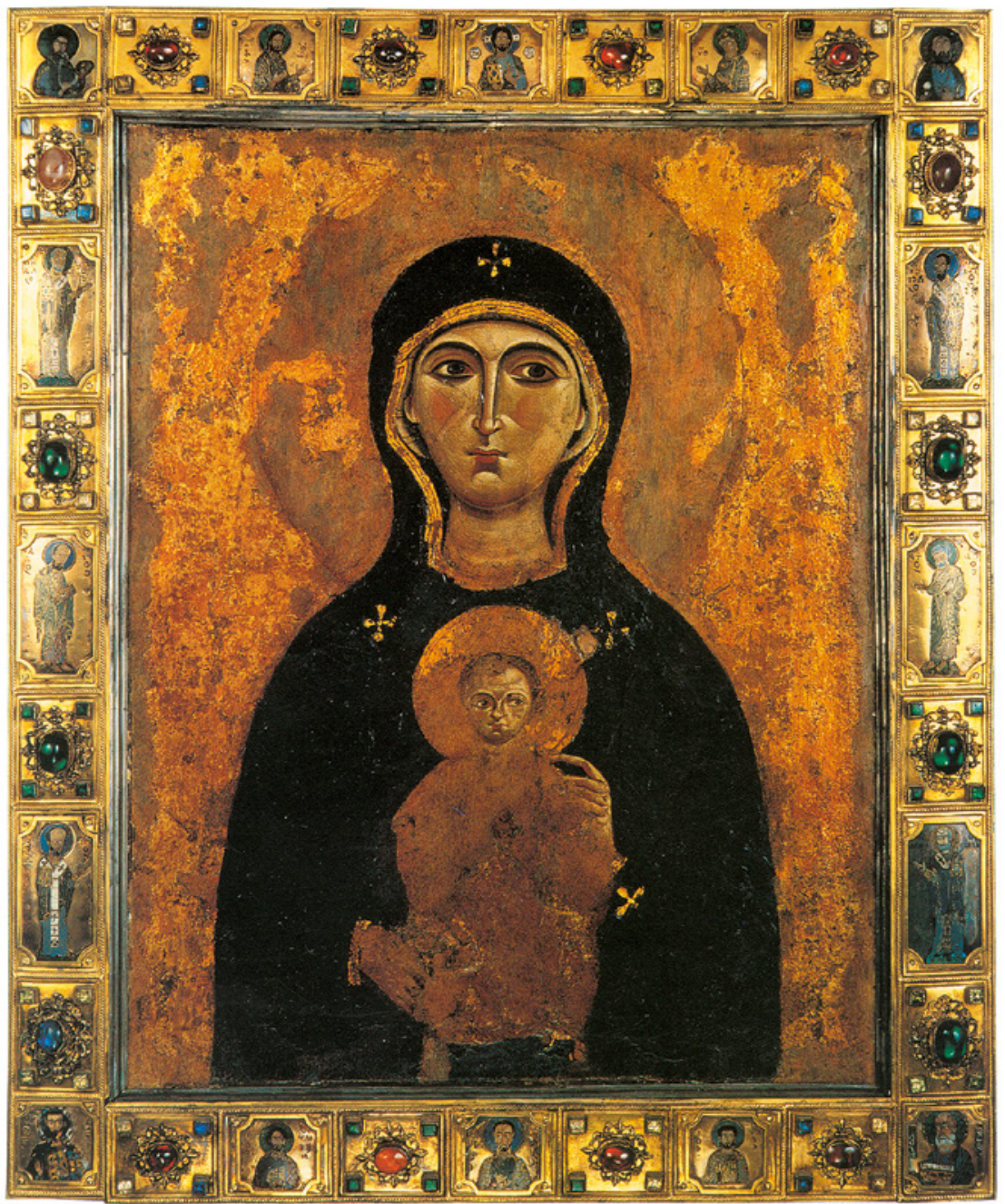

FIGURE 10 Icon of the Virgin Nicopeia, San Marco, Venice

Kassiopi is celebrated today on 8 May with a procession of the icon, but such a practice cannot be confirmed during the period of this study.

Interestingly enough, the broad diffusion and effect of the miracle on a regional level is not reflected in the pilgrims' travelogues. In fact, it seems to go completely unnoticed, since there is not a single reference to it in any of the travellers' narratives. It would be quite improbable that the crews of the galleys sailing through the area were unaware of the miracle, but for some reason pilgrims do not refer to it. In fact, they also cease to mention the actual effigy, the miraculous icon, already from the end of the $15^{\text {th }}$ century, while they continue 
regularly to refer to the church, the lamp and the fig tree, as well as the power of the Virgin Kassopitra to protect the ships and the travellers, who carry on paying their respects to the holy Marian site. ${ }^{81}$

The timing of the miracle and the extent of its diffusion on Corfu, as well as the coasts opposite, could allow the assertion that it was propagated by local actors in order to intensify the fame of the already international holy site on a regional level. One should not forget that the community of Kassiopi, under whose jurisdiction the church of the Virgin fell, profitted from the donations of the pious, and the prospect of a larger income could not be but welcomed. Indeed, after the miraculous healing of Stefanos, the Virgin Kassopitra became a potential protectress of the whole island, thus expanding her influence almost exclusively related to the sea and mariners - on land as well. It is important to note that, already from the 15th century, St Spyridon's relic has been translated to Corfu, and his cult was rapidly growing, elevating him to the throne of the absolute protector of the island. In this view, a reminder of the miraculous power of the Virgin Kassopitra could only benefit the church and the community of Kassiopi. Moreover, the miracle occurred at a time when the Corfiots, both Greek and Latin, really needed a morale booster, a divine power to turn to for support and protection from the growing Ottoman threat.

Aside from the reasons why the miracle was so widely diffused, its surviving narrations can be sources of valuable information about the church, icon and cult practices at Kassiopi. Fortunately, it was recorded already in the 16th century by two Corfiot scholars, Nikander Nucius, who claims he was an eye witness, and Pachomios Rousanos. ${ }^{82}$ Consequently, and leaving aside the features of the miraculous divine intervention, it could be quite safe to consider the data mentioned in these chronicles as genuine. The narration of Nikander Nucius is very short and lacks details, but Pachomios Rousanos's account testifies to what the pilgrims continuously mention, the fact that a Greek monk(s) lived in Kassiopi and most importantly that during the decade of the 153 os an icon was actually housed and venerated in the church of the Virgin. ${ }^{83}$ This last

81 The last reference to the icon was made by Michele da Figline in 1489-149o, Montesano 2010, 58. From then onwards and up until 1549 , many travellers mention the church and its importance as a maritime shrine with no hint of an icon.

82 The description of the miracle by Nikander Nucius was published by Andreas Mustoxidis in 1865 , while the narration of Pachomios Rousanos was published by Michael Landos in 1896. Mustoxidis 1865, 15; Landos 1896, 8-17.

83 The exact date of the miracle did not survive in the early manuscripts. Athanasios Tsitsas supported that the dating to 1530 is a misconception of the date in the first surviving narrations. Since the name of the bailiff at the time of the miracle is known, and consulting the official catalogue of the bailiffs of Corfu, he was able to date the miracle to the 
piece of information, when combined with the testimony of Jean de la Vega, who clearly states that the icon survived the destruction of 1537 , could be used to support the assertion that it was moved after the Ottoman attack to the town of Corfu ${ }^{84}$ It is also worth mentioning that neither Nucius nor Rousanos, even though they both characterise the icon as miraculous, attributed it to Luke.

If we accept what seems to be the most plausible hypothesis - the existence of an icon and its subsequent destruction or removal from the site - we are confronted with an inconsistency. According to scholars supporting the aforementioned interpretation, the icon of the Virgin that performed the miracle in the 153 os was removed by the Venetians from Kassiopi for protection after the destruction of 1537. It was transferred to the town of Corfu and placed in the Roman Catholic church of the Virgin of Tenedos. In 1797, during the first French occupation of the island, it was handed back to the Orthodox, who housed it in the church of Taxiarchis Michael, until that building was destroyed by Italian bombings in 1940 and the icon was moved to the town's metropolis. Kassiopi's most venerated effigy was returned to the church of the Virgin Kassopitra with great pomp on 13 April $1967 .{ }^{85}$ However, the surviving icon, the one that came back to Kassiopi in 1967, is roughly dated to the 16th century (Fig. 11). It is true that, due to a lack of descriptions or other archival or archaeological evidence, the style and dating of the original icon cannot be ascertained. However, the first reference to the icon in 1394 and its attribution to Luke, as well as its probable reproduction in the 16th-century fresco, make the assertion of the existence of a Byzantine icon very plausible. Within this scope and given that the last pilgrim's reference to the icon is dated to 1489 , the destruction of the original effigy and its later replacement could be supported. Taking into consideration the 40-year gap between the last reference to the icon and the time of the miracle, it is probable that the icon to which the healing was attributed was a 16th-century production.

What is more important, in the end, is that the documented absence of the icon after 1537, if not already from 1489, did not affect in any way the importance of the site, mainly for pilgrims and seafarers who continued to evoke the Virgin Kassopitra and pay their respects by saluting it with cannon fire. The cult of the Virgin Kassopitra continued at least up until the 17th and 18th centuries, but the cult practices, as well as the cultic object, changed over the

incumbency of Bailiff Symeon Leonis, that is, between the years 1534-1536, right before the destruction of 1537. Tsitsas 1968, 18-20.

84 According to some scholars, the miraculous icon of the Virgin was removed from the church after the destruction of 1537 to be kept safe in the town of Corfu. Stamatopoulos 1993, 257; Tsitsas 1968, 6.

85 Stamatopoulos 1993, 256-258; Tsitsas 1968, 6. 


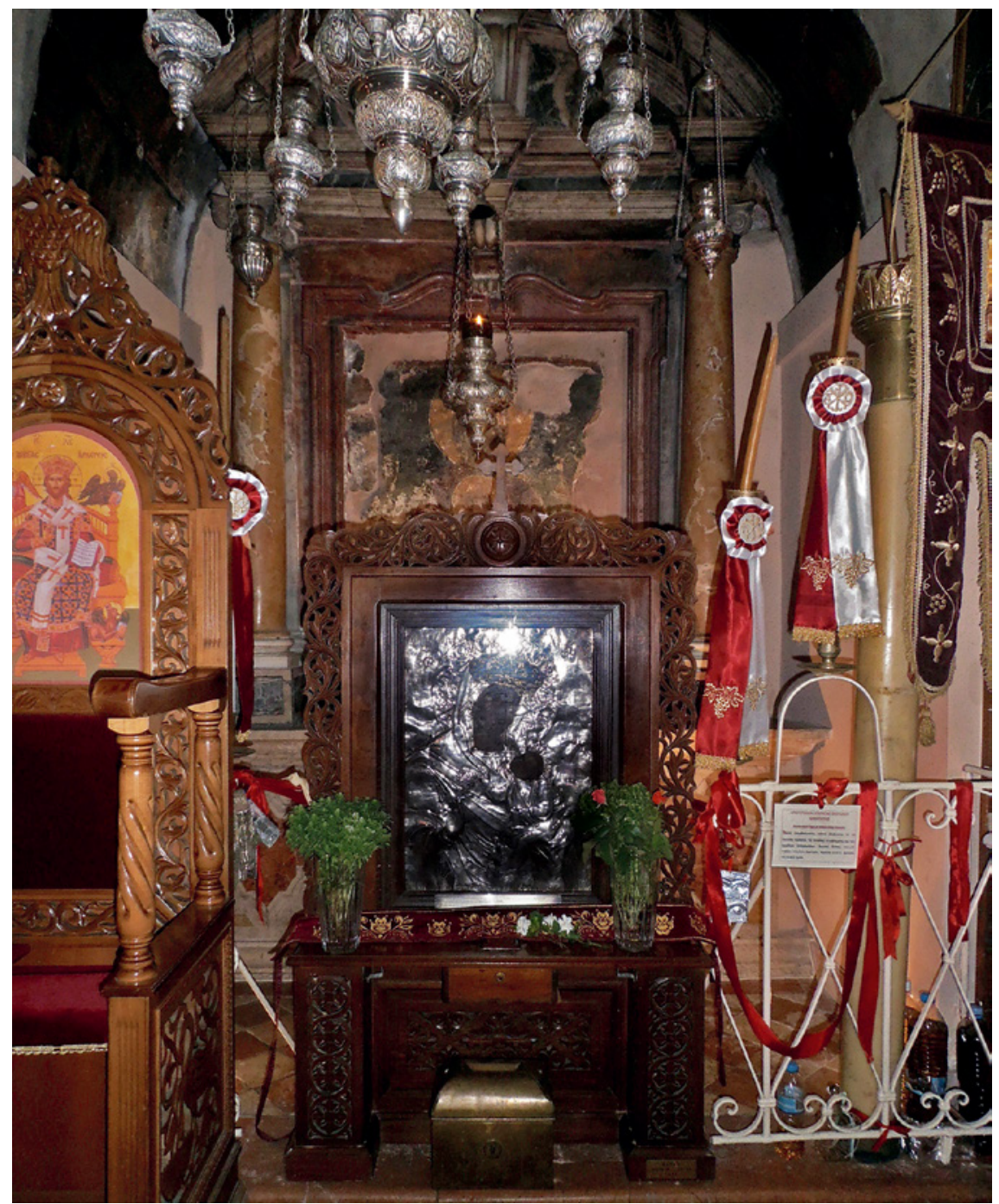

FIGURE 11 The icon of the Virgin Kassopitra, 16th century, in the church of the Virgin Kassopitra, Corfu

course of time. In the description of his visit to the church in 1686, George Wheler, an English clergyman and travel writer, makes no mention of an icon, lamp or fig tree. At his time, the cultic object was a 'shiny and polished' fresco on the wall. ${ }^{86} \mathrm{He}$ also points out the economic aspect of the Virgin Kassopitra's

86 'Cette image est peinte sur la muraille, \& fort polie \& luisante.' Wheler 1686, 43. 
cult, as he explains that the pious used to place coins on the fresco to see if they would stick on it or fall down, thus determining if the person they had in mind was alive or dead. Following that practice, which the Englishman characterises as a ridiculous fraud, the Greek monks collected all the coins. ${ }^{87}$ In the mid18th century, a quite unexpected source provides information about the cultic practices in the church of the Virgin: Giacomo Casanova, who fled the town of Corfu after an affair with the wife of a Venetian admiral to hide at what was at the time the small village of Kassiopi, describes in detail a ritual during which the Greek priest 'transmits the Holy Virgin's oracle' to a pious Greek travelling from Cephalonia to Venice. The Italian adventurer and author also points out that the man 'gives the impostor [the Greek priest] more money', affirming that the practice of the pilgrims to make offerings to the Virgin continued. ${ }^{88}$ There is again no reference to an icon or a lamp in the church, but apparently its fame as miracle worker still carried on.

At the beginning of the 19th century the church came under the jurisdiction of the Greek state and the municipality of Kassiopi. In 1967 the icon that according to the legend healed young Stefanos in the 1530s was moved back from the town of Corfu to be housed and venerated in the church. It remains there to this day, along with the votive icon of Theodoros Poulakis.

After stopping at or saluting from afar the church of the Virgin at Kassiopi, pilgrims' galleys would enter the port of the capital city of the island, the town of Corfu. The walled part of the city was strongly fortified, very densely built and guarded by two towers on top of two protruding rocks at its east and west sides (Fig. 12). Those two rocks, markedly imposing as seen from the sea, are the first element of the town to be mentioned by almost all of the travellers. The first impression of the naturally fortified small medieval town, the città or terra, seems to be more or less common for the pilgrims, and one of its more vivid descriptions, combining almost all of the facts mentioned in most of the travelogues, is provided by the Italian pilgrim Pietro Casola (1494):

87 ' [... $]$ une tromperie ridicule'. Wheler 1686, 43. An analogous practice that survives to this day can be seen in the church of St George in Omorphokklisia in Kastoria, where coins are placed on a 13th-century wooden repoussé icon of St George.

88 Casanova 1997, 119. About the money offerings pilgrims used to make to the Virgin, see n. 23 above. 
The town of Corfu is built on a hill and has a large borgo on the plain; as I said, it has two strong castles, situated very close one to the other. [...] The whole city is built on the rock; the aforementioned castles have very few inhabitants, who notably rule the city and the borgo. [...] The city is full of buildings, so close together that the roof of the one touches the roof of the other, thus the sun does not really annoy the people. [...] The city, along with the borgo, used to be like a small island; now the Signoria separated them with a very thick wall made of square blocks $[\ldots] .^{89}$

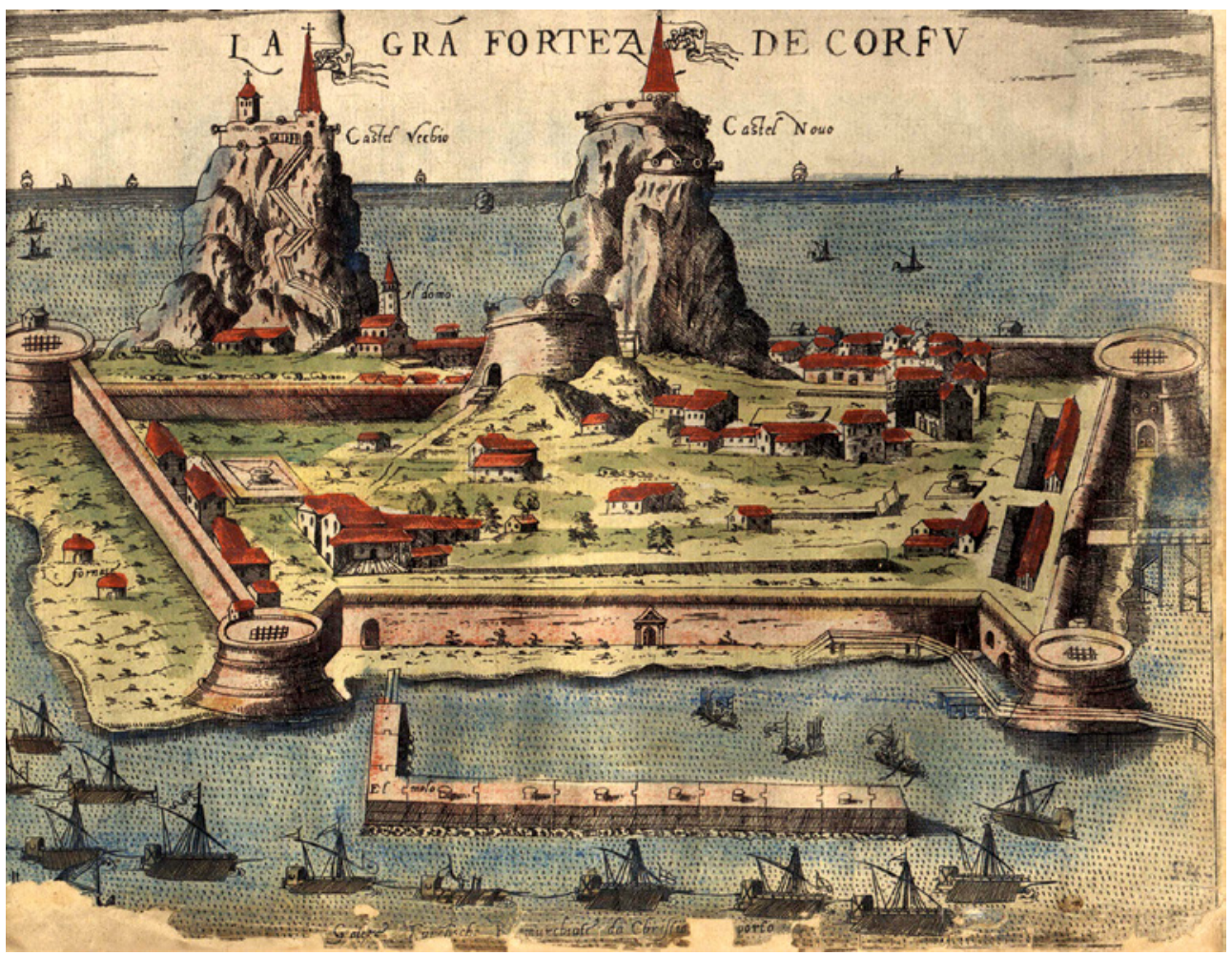

FIGURE 12 View of Corfu, 1573, engraving

89 'Questa cità de Corffù è posta in monte et ha uno grande borgo in piano; como ho dicto, ha dui castella fortissimi, vicini l'uno a l'altro. [...] Benché tuta la cità è posta sopra saxo, dicti castella hano poca abitatione e signorezano la cità e lo borgo molto notabilmente. [...] È dicta citade molto spessa de edifitii, ita che l'uno tecto tuca l'altro et el sole non li da tropo noglia. [...] Dicta citade soleva, era a modo de una insuleta insema con lo borgo; ora la Signoria l'à separata dal borgo, con uno muro grossissimo, facto de saxi quadri [...].' Paoletti 2001, 136-137. See also the English translation of Casola's pilgrimage in Newett $1907,185^{-186 .}$ 
Another noteworthy fact concerning the first mentions of pilgrims in regard to Corfu is the awareness that they were entering the territory of Greece and the land of the former Byzantine Empire. ${ }^{90}$ In addition, most of them seem to have possessed knowledge of many historical facts concerning the island, which are mentioned in greater or lesser detail in the travelogues. With the few exceptions of (in their most part German) travellers who refer to the island's history from the ancient period, the information provided by the majority of the pilgrims is related to its Christianisation and the widespread legend of the martyrdom of Kerkyra, the young daughter of a Roman vice consul of the island, Kerkylinos, who, according to tradition, was converted to Christianity by St Jason. ${ }^{91} \mathrm{~A}$ great number of them also mention the port's capacity for many galleys and the fact that usually more than two were stationed there for protection, pointing out Corfu's importance as a naval station and frontier for Venice's interests in the area.

The small fortified part of the capital, the città of the Venetians, retained its main characteristics until the end of the 16th century, while it was constantly evolving and shaping within its narrow boundaries. A number of pilgrims mention seeing fortification works being carried out during their visit to the island throughout the time frame of this study, that is, before the final fortification of the borgo at the end of the 16th century (Fig. 13). ${ }^{92}$

The depictions of Corfu in the isolarii of the period, as well as in some pilgrims' narratives, as abstract as they may be, provide quite an accurate idea of the form of the town with the two imposing rocks and the cathedral standing out between them (Fig. 14) ${ }^{93}$ Because of the limited space within the città,

$90 \quad$ See indicatively Hans Tucher (1479-1480): 'Item Curfuu jst ein krichische stat [...]'. Herz 2002, 358. Anonymous, Le voyage de la saincte cyté de Hiérusalem (1480): 'Corphol est une cité et archevesché de la seigneurie de Venise et la premiere ville de Grece [...].' Schefer 1882, 43. Pierre Barbatre (1480): 'Courfoul est une cité appartenante ou que tiennent les Veneziens et est en Grece.' Pinzuti and Tucoo-Chala 1972-1973, 118. Pietro Casola (1494): '[...] principio de la Grecia [...]'; Paoletti 2001, 135 .

91 The most detailed and complete historical review is provided by the Dominican friar Felix Fabri, who underwent two pilgrimages, in 148 o and in 1483-1484. Hassler 1843-1849, vol. 1, 51-54.

92 Georges Lengherand of Mons (1485-1486) described the town and its fortification as follows: 'Au dessus d'icelle ville il y a deux haultes roches, l'une plus haulte que l'autre, et sur chascune roche ung chastel. Laquelle ville l'on a fort commenchié à le fortiffier, depuis XIIII ans encha, de tours et murailles qu'ilz nomment faulses brayes, car icelle muraille est au devant de la vieze nuraille; aussy ilz y ont fait une nouvelle porte. Et encoires à ceste heure y avoit grand nombre d'ouvriers y ouvrans.' Ménilglaise 1861, 95.

93 Voskopoulou 2005, 42-43. As already indicated, the first feature most of the pilgrims mention about the town of Corfu are the two castles on the two rocks that guard it. Louis 


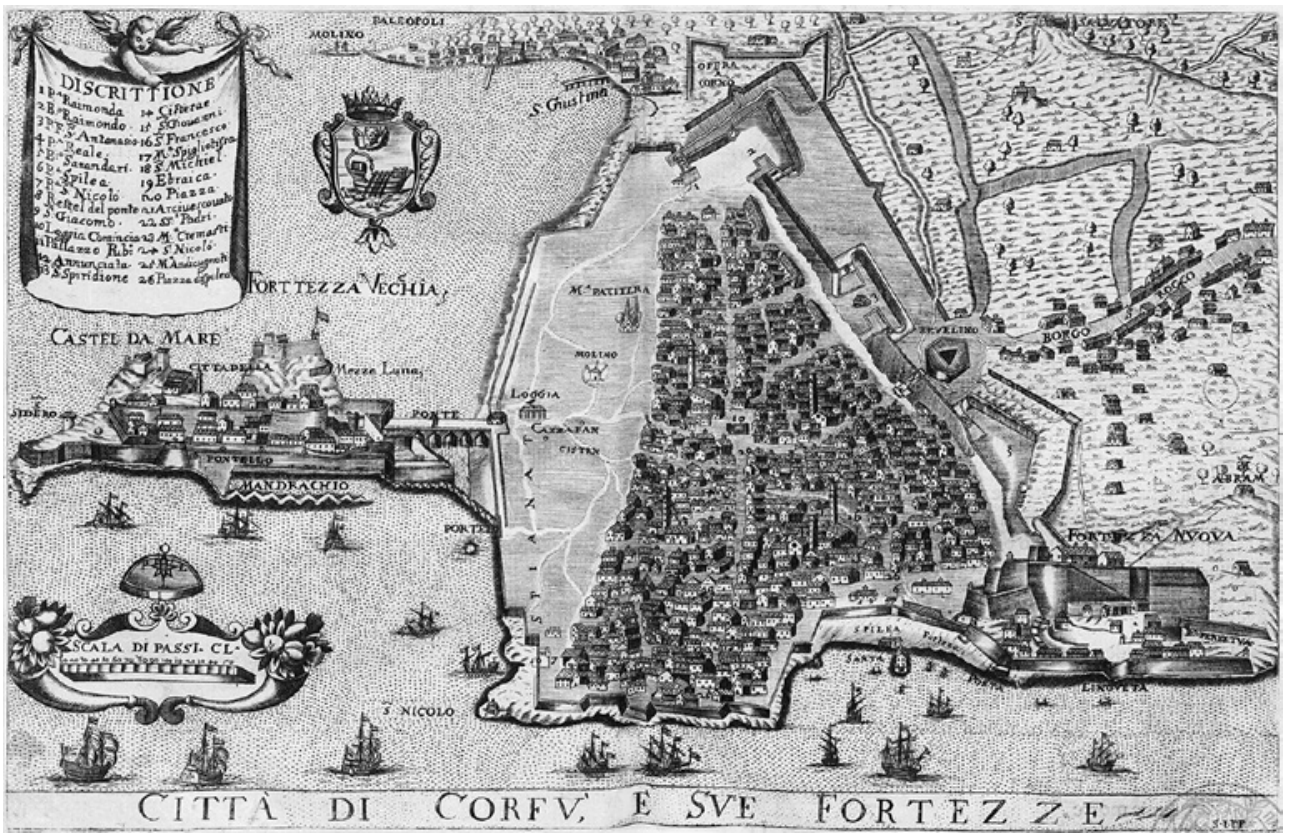

FIGURE 13 The city of Corfu and the borgo after the 16 th-century fortification works

already from the 13th century its inhabitants started gradually moving outside the walls, where they built their houses, warehouses, commercial stores and, of course, churches and monasteries. These structures were organised around the port and the market, and soon the area's population ended up being almost seven times more than that of the city. ${ }^{94}$ Maps of the 16 th century characterise the city's outskirts as il borgo or el bazaro, emphasising the fact that most of the commercial activities of Corfu had been moved out of the castle (Fig. 15) ${ }^{95}$ During the Ottoman siege of 1537, the borgo suffered severe damage, if not complete destruction. It was then that new fortification works started to be carried out in and around the castle, while the borgo was finally fortified after

de Rochechouart in 1461 describes: 'Sunt duo castra fortissima sita super duas arces [...].' Couderc 1893, 232. Pierre Barbatre (1480): 'Le chasteau est double sur deulx roches bien fors et bien haulx avirones [sic] de la mer de toutes pars fors vers la ville le long d'ung tret d'arc.' Pinzuti and Tucoo-Chala 1972-1973, 118. Wolfgang Zillenhart (1495-1496): 'Item zwischen den zway schlosse ligt ain kirch [...].' Gebele 1932-1933, 81.

94 Karydis 2007a, 17-18; Voskopoulou 2005, 36-37.

95 Voskopoulou 2005, 42-43. The Italian pilgrim Pietro Casola corroborated the aforementioned: '[...] a lato al porto, egli uno grande borgo unde al tempo si fano li mercati et è cosa molto spatada; e lì sono tute li ostarie e tavern [...].' Paoletti 2001, 136. 


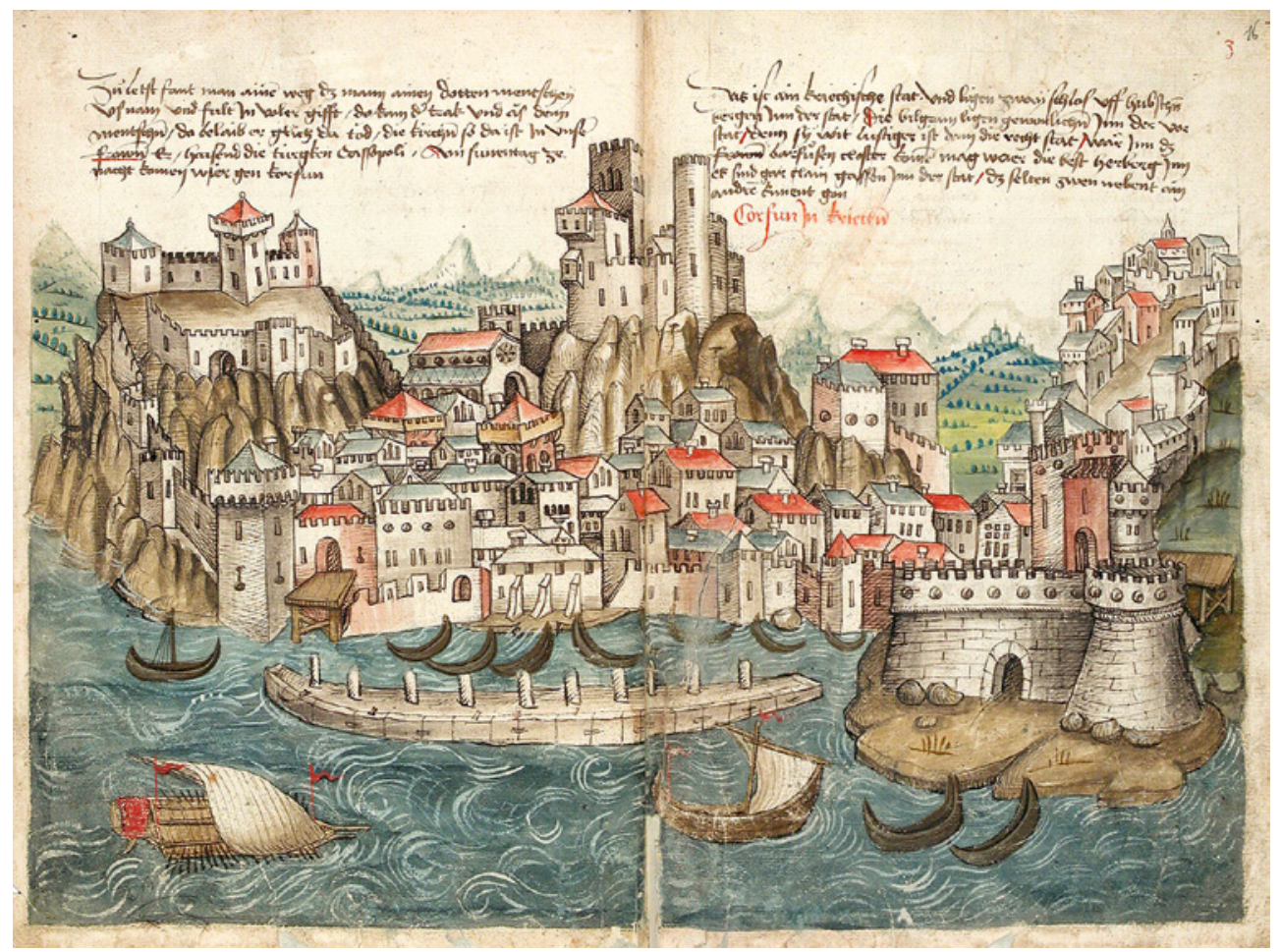

FIGURE 14 View of Corfu, c. 1487, manuscript illumination

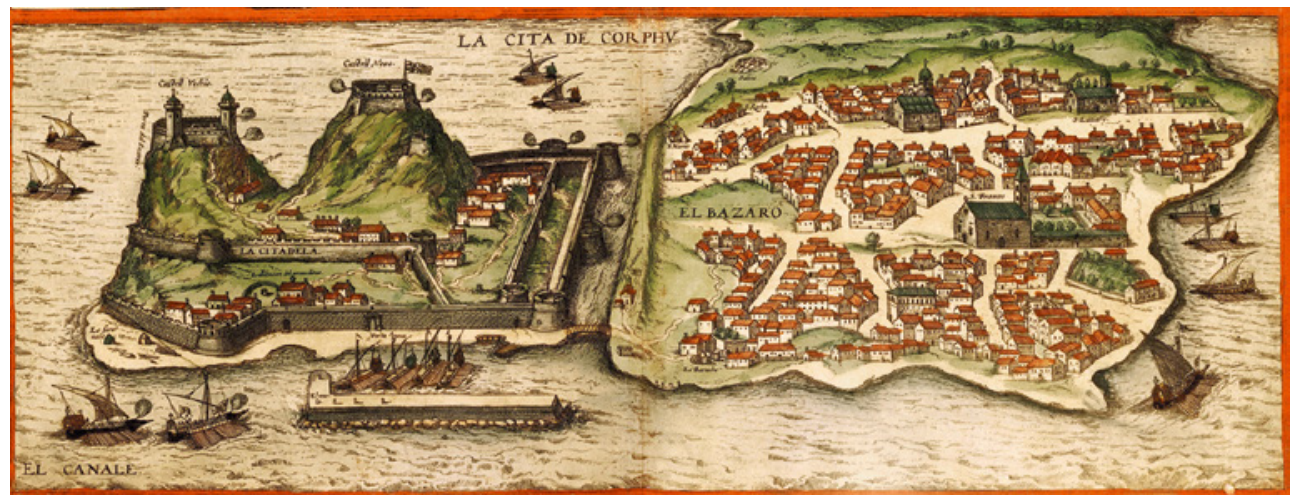

FIGURE 15 The town of Corfu and its borgo, c. 1575, engraving 
the siege of 1571, the cathedral was moved to the church of St Jacob, and the old city became a zone of administrative and military use. ${ }^{96}$

So, up until the end of the period of this study, the town of Corfu that pilgrims saw was the small walled part of the Venetian città. The confined and densely built city did not appeal to Western visitors. In 1485 Georges Lengherand of Mons describes a well-fortified town built on a rock, but at the same time rather unpleasant, with narrow streets and a bad smell, while in 1494 the Italian pilgrim Pietro Casola writes that it would actually have been better to remain on the galley ${ }^{97}$ Almost all of the travellers visited the borgo, since most of the taverns and places of accommodation were located there, as well as the two most eminent Latin religious institutions: the Augustinian monastery of St Mary of the Annunciation, or the Annunziata, and the Franciscan monastery of St Francis. The latter was the place where most of the pilgrims lodged for the period when their galleys were docked at the port of Corfu. Many of them mention that in their travelogues, and in general the Franciscan monastery amasses most of the pilgrims' references concerning the churches or religious institutions of the town.

Venetian Corfu, both the città and the borgo, had surprisingly few Latin churches in comparison to Orthodox ones. The recorded Catholic religious institutions within the time frame of this study are only nine: the cathedral of Sts Peter and Paul, which was located in the walled city, the monastery of St Justine, the churches of St Catherine, St Rocco, St Catald, Sts Jacob and Christopher and St Nicholas and the mendicant monasteries of the Augustinians and the Franciscans, all built in the borgo. ${ }^{98}$ On the other hand, the town and the borgo were full of Orthodox churches. All the aforementioned appear often in the pilgrims' travelogues: in 1480 the French priest Pierre Barbatre attests that there

96 Between the years 1577 and 1588 the so-called Nuova Fortezza was built by eminent Venetian military engineers. About the Ottoman sieges, the fortification and the architecture of the town of Corfu, see Chytiris 1969; Agoropoulou 1976; Giotopoulou 1997; Voskopoulou 2005.

97 Georges Lengherand of Mons (1485): 'Ce fait allâmes voir la ville que est forte ville sur ung hault tertre de roches, mais par dedans il y fait ort et mal plaisant, car les rues y sont estroittes et y fait ort et puant.' Ménilglaise 1861, 95. Pietro Casola (1494): ‘[...] in el vero era migliore stare in galea'. Paoletti 2001, 136 .

98 According to archival documents, in 1583 there were 122 churches in the town of Corfu and its borgo and only nine of them were Latin. Papageorgiou 1920, 181, 191; Tsitsas 1969, 103, 119; Karapidakis 2011, 143; Karydis 2007a, 107-243; Karydis 2010, 313; Agoropoulou 2004, 226. See also Maltezou 1991; Karydis 2011. 
were many parochial churches, all following the Greek rite, while at the cathedral the services were held in both the Greek and the Latin languages. ${ }^{99}$

The pilgrims' first encounter with an Orthodox population and its religious practices is clearly reflected in their travelogues, either with extended mentions about the common religious ceremonies of Latins and Greeks and the particularities concerning the liturgies held in the island's Catholic churches or by the absence of references to the religious institutions in general. ${ }^{100}$ This same approach towards Orthodox or even Latin churches in the former Byzantine Greek territory can be observed in all the areas of interest of this study, and the towns of Corfu and Candia are the most interesting examples.

The particular modus vivendi that developed in Corfu - as well as in Modon and Candia - and the way it was expressed in religious life with common liturgies and processions seems to have intrigued the pilgrims, many of whom make mention of the 'peculiar' religious practices they encountered while in Greece. Gaudenz von Kirchberg, a German pilgrim who visited Corfu in 1470, describes the celebration of Corpus Domini by the Corfiots of both rites. ${ }^{101}$ The Festum Eucharistiae, or Corpus Domini, was celebrated grandiosely in the town of Corfu with a procession and the participation of representatives of

99 'La grande eglise est audit chasteau en hault et se fait le service en l'usage de langue latine honnestement et par belle ordonnance. [...] et si il y a grant nombre d'eglises parrochiales toutes a la mode et usage grec. Ilz ne font pas le service comme les autres ne les sacremens de l'eglise.' Pinzuti and Tucoo-Chala 1972-1973, 118. In the same year the anonymous author of Le voyage de la saincte cyté de Hiérusalem writes: 'Il y a environ dix huyt ou vingt eglises èsquelles tout le service se dit en grec, excepté les Cordelliers qui sont latins en l'eglise cathedralle en laquelle on chante aulcunes fois grec et aulcunes foys latin.' Schefer $1882,43-44$.

100 Very few of the pilgrims who mention stopping at Corfu refer to the churches and monasteries of the town. Since it is rather improbable they did not see any of them, one can assume that the lack of references is due to the fact that they were either strange or indifferent to them. At this point, it is important to stress once again that the church of the Virgin in Kassiopi is examined separately; therefore all the statistics mentioned in this chapter concern only the town and borgo of Corfu.

101 'Und am Gottesleichnamsthag (21. Juni) gienngen in der proceß, am ersten Kriechische priester mit den Kriechen und trueg inen ainer ain tafel vor, was an der ainen seitten daran gemalen, Unser Lieben Frawen piltnuß, die hat Unseres Lieben Herren pildung auf der schoß, und an der andern seyten sant Pauluß pilde. Dem volgten die Kriechen nach und sungen alle nichts anderst dann kirieleyson. Und man saget Unser Lieben Frawenpilde an der tafel thät grosse zaichen. Darnach gienngen in der prodeß die minichen, layenpriester; und der verweser des pischoffs trug das sacramennth, und die Kriechen feyrten den thag nicht, sonders y arbaiten, wie an ainem werchtag.' Röhricht $1905,108$. 


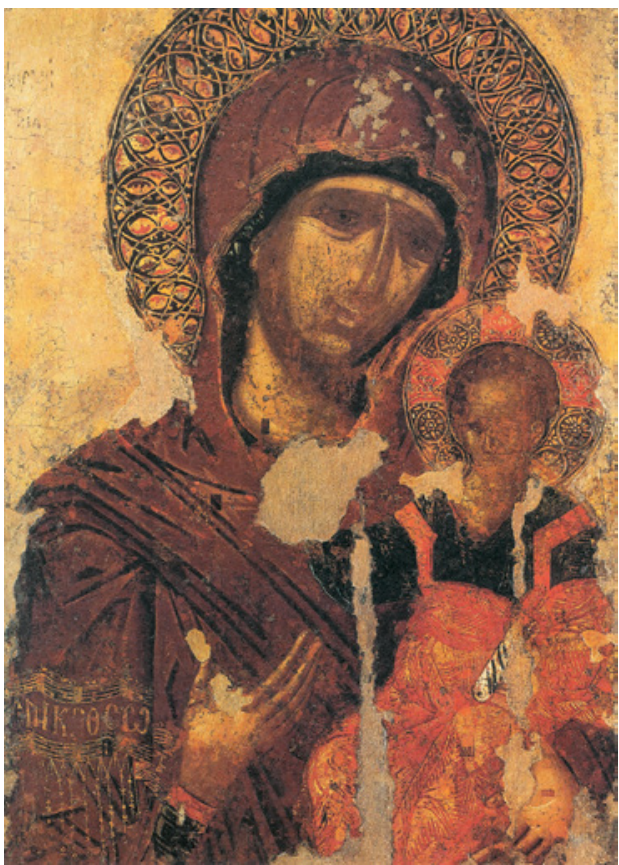

FIgURE 16a The Virgin Demosiana (obverse of Fig. 16b)

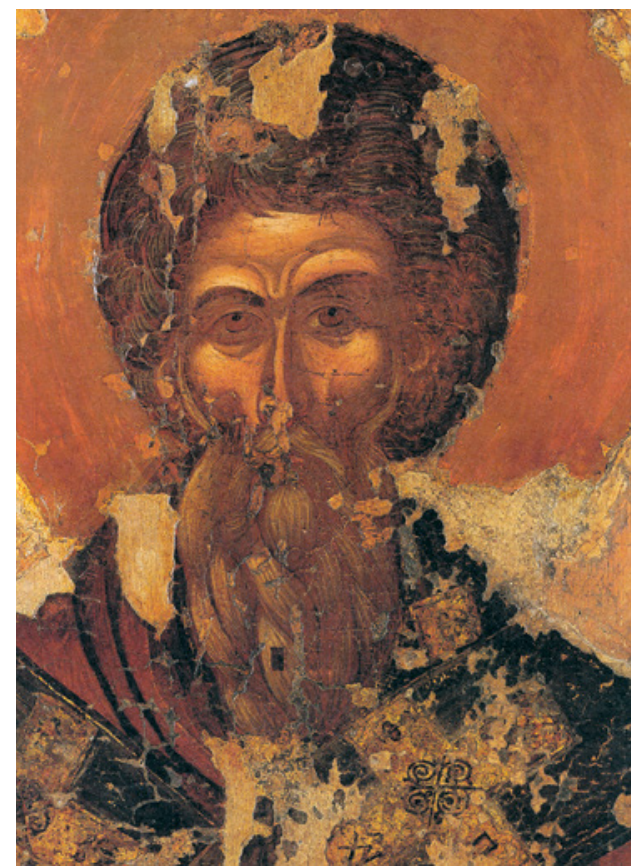

FIGURE 16b St Arsenius of Corfu (reverse of Fig. 16a)

both clergies. During the procession the Orthodox carried the icon known as the Virgin Demosiana, which, as Gaudenz von Kirchberg describes it, depicts the Virgin on one side and St Arsenius (mistakenly identified as St Paul) on the other (Figs 16a, 16b). ${ }^{102}$

The unusual attire and habits of Greek priests are also remarkable subjects for a Western visitor, discussed in many travelogues, not always without hints of discontent. In 1480 Pierre Barbatre wrote about the Greek priests wearing their 'peculiar' big hats and being allowed to have a spouse and children, while

102 About the celebration of Corpus Domini in Corfu, see Nikiforou 2014, 68-69, 73-76; Tsitsas 1969, 141-144; Papageorgiou 1920, $76-78$. The icon of the Virgin Demosiana is a 14th-century Byzantine icon, which belonged to the 'Sacred Order' and was kept in the church that served as the seat of the Greek protopapas. Vokotopoulos 1986, 351-355; Vokotopoulos 1990, 4-6; Tsitsas 1970, 108-115. 
the French pilgrim Antoine Regnault (1549) described the buildings of the Orthodox churches, as well as some of the local religious rituals. ${ }^{103}$

Besides the interest shown by the pilgrims concerning the new - and strange to a Western eye - reality of a Levantine city where the Orthodox were free to express their religious sentiment following their Byzantine tradition, references to specific Orthodox churches are very few and mainly concern the church of St Nicholas dei Vecchi. In his description of the town Antoine Regnault provided some interesting information, noting the great devotion of the Greeks to the Virgin: 'We entered the port of Corfu, where we stayed for three days, during which we visited many churches dedicated to the Virgin, far from Corfu, around three or four leagues, and which the Greeks greatly revere and honour.'104

Only two other Orthodox churches of the town are mentioned in pilgrims' narratives: the church of St Nicholas by the Sea by Paul Walther Guglingen (1482) and the church of the Virgin Limniotissa by Felix Fabri (1480, 14831484). ${ }^{105}$ It is important to note that neither of those two travellers visited the aforementioned churches; instead they saw them from aboard the ship while navigating into the port of Corfu.

\subsection{The Church of St Nicholas by the Sea}

The identification of the church seen by the Franciscan friar Paul Walther Guglingen is not an easy task. There were many churches dedicated to St Nicholas in the town of Corfu. The one that best fits the description of a

103 Pierre Barbatre (1480): 'Les prebstres sont tous mariez et ont fame et enfans. Et nota se ilz ne leur suffit d'une fame ou qu'ilz soient prouvez adulterez, ilz sont privés de celebrer, maiz usent de toute aultre office. Les prebstres sont vestus aultrement que les gens laïz et ont tous ung grant chapel et vivent de ce que on leur donne a leur offrende ou aultres sacremens car ilz n'ont point de dismez.' Pinzuti and Tucoo-Chala 1972-1973, 118. Antoine Regnault (1549): 'Les Eglises ne sont guieres belles, à la porte de chacune ont vn fer epais de quatre doitz fait en façon d'arc, \& quand frappent dessus, rend le son, comme une cloche, \& n'ont en vsaige autre sonnerie par toutes les Eglises Grecques. Leur ceremoniee est de s'entreacoler, \& baiser. Quand un Grec est trepassé, les femmes s'assemblent \& vont sur la fosse, qui ne font tout le iour que lamenter, batans leur poitrine, qui est pitié de les voir plorer.[...] La remembrance des Images est faicte en plate painture, \& à les voir fort anticques, \& n'ont en vsage les Images faictes abesse.' Regnault 1573, 21.

104 'Nous fumes encrez au port dudict Corfou par l'espace de trois iours, pendant lequel temps visitames plusieurs Chapelles de la vierge Marie, loing de Corfou enuiron trois, ou quatre lieues, que lesdicts Grecz ont en grande reuerence, \& honneur.' Regnault 1573, 21.

105 Hassler 1843-1849, vol. 3, 349; Sollweck 1892, 77. 
small church built on a rock in the sea seen by a traveller of 1482 is the church of St Nicholas ' $\tau \omega \nu \pi \tau \omega \chi \omega$ ' $\nu$ ' (of the poor). The church had been identified by Spyros Karydis as St Nicholas 'poverello', based mainly on the correlating denominations, but later on he doubted that identification (Figs 17a, 17b). ${ }^{106}$ The date of the construction of the church is uncertain, but it is the only church of St Nicholas mentioned in archival documents around the period of its mention in Paul Walther Guglingen's travelogue.

If the church in question is actually St Nicholas 'poverello', archival documents testify to its existence already in 1414; it was then that, according to the plans of the fortification of the borgo, the new walls would be built near it. In any case, St Nicholas ' $\tau \omega \nu \pi \tau \omega \chi \dot{\omega} \nu$ ' appears by that name in archival documents since 1502. A notarial document of 1523 mentions its owner, Nikolaos Agapitos, or Sahlikis, and from the 16th century onwards the church also appears as St Nicholas 'Sahlikis' or 'on the seashore'. The church seems to have been of reverence for the seafarers, who often made donations to it. Up until the 18th century the church, like most of the churches of Corfu, was private and belonged to the Sahlikis family, until the 19th century, when it came under the jurisdiction of the community of Corfu. ${ }^{107}$

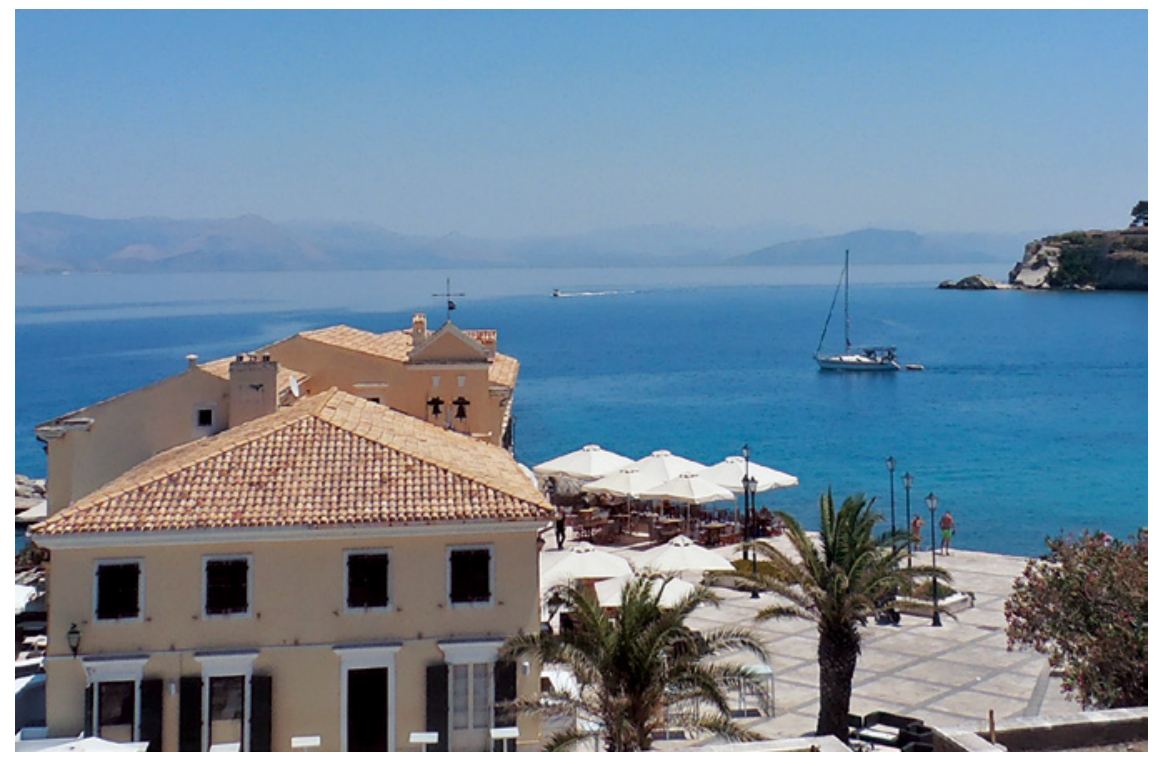

FIGURE 17a The church of St Nicholas, Corfu, view from the west

106 Karydis 1999, 281; Karydis 2007a, 162-164.

107 Karydis 1999, 281; Karydis 2007a, 162-164; Papageorgiou 1920, 206. 


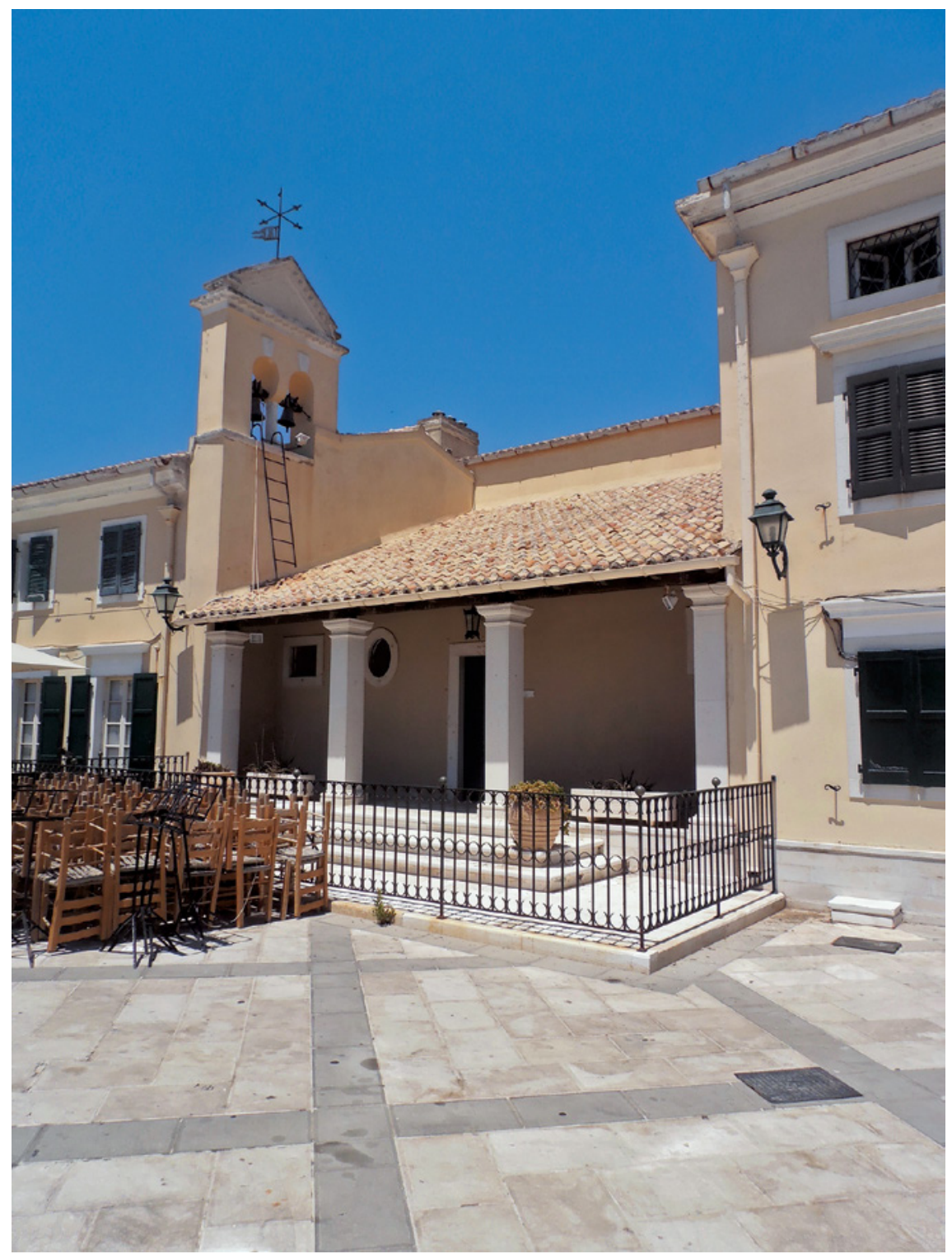

FIGURE 17b The church of St Nicholas, Corfu, view from the south

The monument underwent many changes during its history. Most probably it was a typical Ionian church: a small-scale, one-aisled, wooden-roofed basilica. After its destruction during World War II, it was restored in the same type, preserving some of its original elements. Due to the particularity of the 
building complex on which the church is embedded, today it has neither a west entrance, nor an apse at the east, while its only entrance is on its south side. It is still officiated (although on a non-regular basis).

The church of St Nicholas is mentioned by only one pilgrim, Paul Walther Guglingen, who visited Corfu in 1482 . He described it as a small church on the seashore near the city and mentions that three Greek priests resided there. ${ }^{108}$

\subsection{The Church of the Virgin Limniotissa}

The church of the Virgin Limniotissa appears for the first time in archival documents of 14 March 1497, so this date can be used as a terminus ante quem for its construction (Fig. 18). Very little information about it survives and it all comes from archival documents; one of them, dating to 1567 , records that it

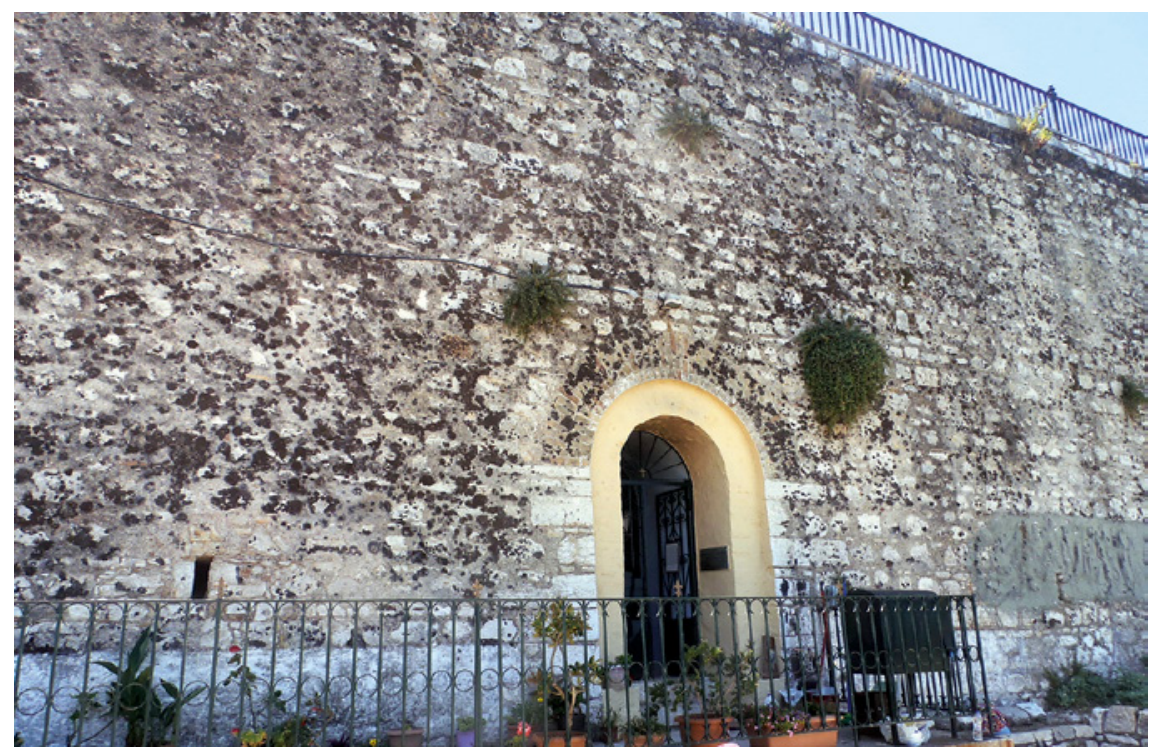

FIGURE 18 The church of the Virgin Limniotissa, Corfu

108 Paul Walther Guglingen's full description of the church: 'Demum navigavimus versus civitatem Corffu, et prope civitatem in mare est quedam parva rupis vel petra, et in illo est edificata una parva ecclesia et domicula in honorem sancti Nicolai, et morantur etiam ibi tres greci sacerdotes.' Sollweck 1892, 77 . 
belonged to the guild of caulkers. ${ }^{109}$ By the 18 th century the church belonged to the community of Corfu and was called the Virgin 'of the Sea.'110

The church was located directly below the northern city walls and was demolished by the Venetians during the construction of the walls from 1571 to 1580 , thus its architectural type is unknown, although it could be assumed that it followed the typical Ionian Islands type of the one-aisled, wooden-roofed basilica. The church was either enclosed in the new walls and demolished in a later period or demolished during the construction of the fortifications, while the altar was preserved. ${ }^{111}$ Today, in its place, there is a small chapel dedicated to the Virgin Megalomata. Inside the chapel there is a 16th-century fresco of the Virgin with the inscription 'Panagia Limniotissa', which used to be the southern altar of the older church (Fig. 19). ${ }^{112}$ The orientation of the chapel, as well as the level of its surrounding walls, suggest that the building was not initially constructed as a church, but was turned into one at a later date. ${ }^{113}$

The Virgin Limniotissa is mentioned by only one pilgrim, the German Dominican friar Felix Fabri. He reports that during his first pilgrimage, in 1480, the church was being constructed and was just a wooden chapel, while by the time he visited Corfu again, in 1483 , its construction was completed. ${ }^{114} \mathrm{He}$ also adds that the church was built by the seafarers, which could be supported by documents attesting that, at least in the 16th century, it belonged to the guild of caulkers. ${ }^{115}$ Fabri also mentions that it was a Latin church, a fact that contradicts the surviving information that the church belonged to the Orthodox rite. However, the possibility that it served for a period of time as a Latin or a double-rite church cannot be excluded.

\footnotetext{
109 Karydis 1999, 284.

110 Papageorgiou 1920, 198-199.

111 Karydis 2007a, 176.

112 Karydis 1999, 284; Karydis 2007a, 175; Papageorgiou 1920, 198-199.

113 Karydis 1999, 284; Karydis 2007a, 175.

114 'Iuxta mare est ecclesia beatae Virginis, jam quadris aedificata, ubi in prima mea peregrinatione stetit solum lignea capella, et est etiam ecclesia latina, galeotarum eleemosynis constructa.' Hassler 1843-1849, vol. 3, 349.

115 See n. 109 above.
} 


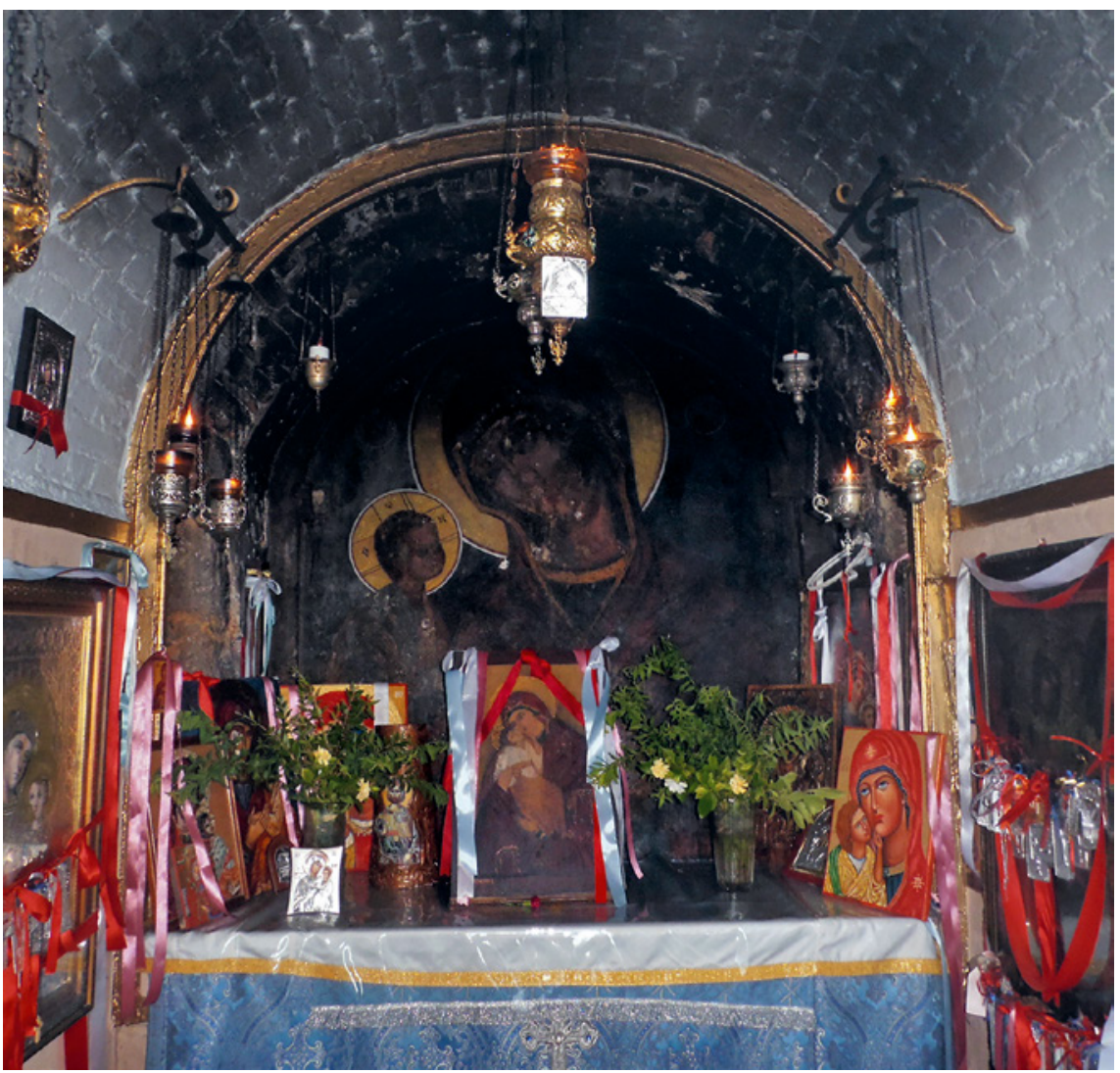

FIGURE 19 The 16th-century fresco of the Virgin in the church of the Virgin Limniotissa, Corfu

\subsection{The Church of St Nicholas dei Vecchi}

The only Orthodox church pilgrims actually visited in the town of Corfu and described is the church of St Nicholas dei Vecchi, where the relics of Sts Spyridon and Theodora were kept and venerated (Fig. 20). St Nicholas dei Vecchi is one of the oldest churches in Corfu and obtained its present form at the beginning of the 16th century. ${ }^{116}$ Its time of construction cannot be determined with certainty, but it is considered to have been built on a pre-existing 14th-century building. ${ }^{117}$ Continuous mentions of the church in archival documents from 1487 and throughout the following century indicate that it was

\footnotetext{
116 Agoropoulou 1976, 282.

117 Papageorgiou 1920, 206; Gallas 1992, 220.
} 


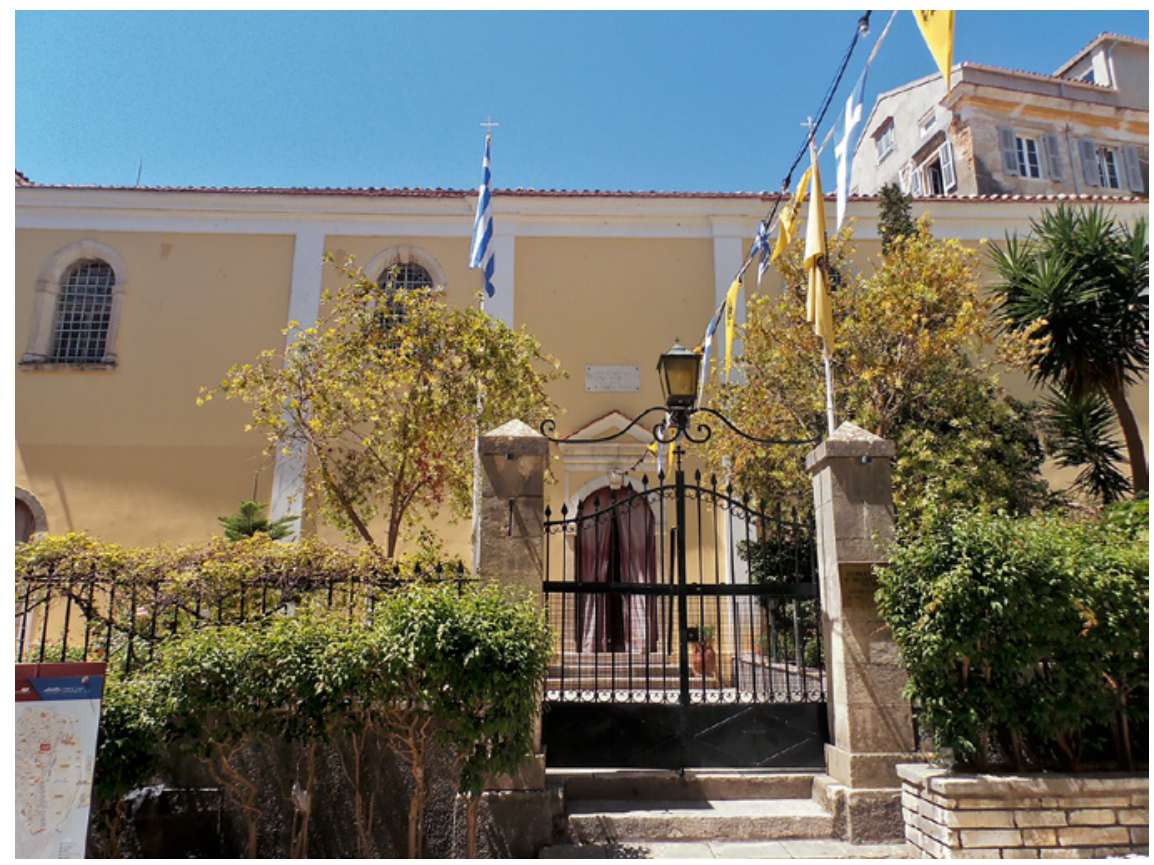

FIGURE 20 The church of St Nicholas dei Vecchi, Corfu, view from the south

not moved from its original place. ${ }^{118}$ It probably suffered damage during the Ottoman sieges of 1537 and 1571, but obviously was restored and continued to function. ${ }^{119}$

St Nicholas is of the typical architectural type of the Ionian Islands' churches: a one-aisled, wooden-roofed basilica with an exonarthex surrounding its west, north and south sides. Due to the particularly sharp gradient of the area, there is no entrance at its west side, and the west part of the narthex is directly connected to the main aisle, without the intermediation of a wall or doors. The north and south parts of the narthex do not exist today, but traces of them are still visible. The main aisle is particularly long $(23.20 \times 8.40 \mathrm{~m})$, while at the east it forms a tripartite sanctuary with central hexagonal and two lateral semi-circular niches (Fig. 21). ${ }^{120}$

118 The first mention of the church, under the name St Nicholas 'ton Alvaniton', is in a notary document of 22 March 1497. Already in 156o the church was a prosperous institution, with much property in land and money. Karydis 1999, 280; Karydis 2007b, 164; Papageorgiou 1920, 206.

119 Karydis 1999, 280; Karydis 2007b, 164.

120 Agoropoulou 1976, 282. 


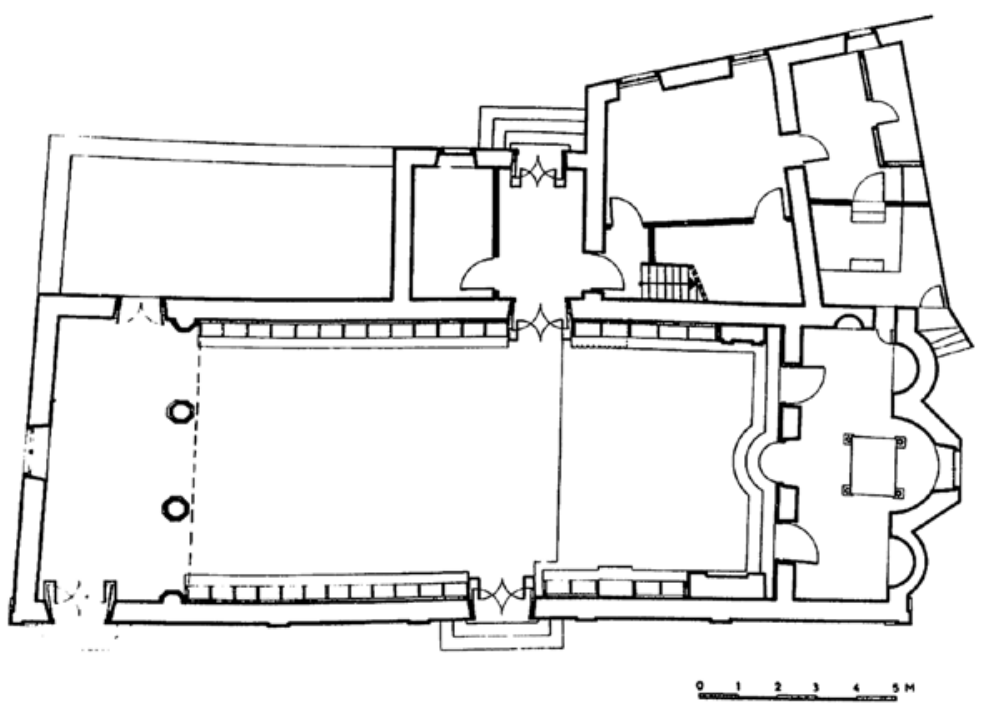

FIGURE 21 Plan of the church of St Nicholas dei Vecchi, Corfu

Inside the church there is a beautifully carved marble iconostasis of the 17th century with Corinthian columns and shell conglomerations, decorated with icons connected to the school of the famous Cretan painter Emmanouil Tzanes-Bounialis (Fig. 22). ${ }^{121}$ St Nicholas dei Vecchi is one of the very few churches on the island that has a pulpit located high on the north wall and accessed through the exonarthex. According to the Corfiot custom, the members of the fraternity that owned the church were buried under the floor of the exonarthex. Some of the burial plaques are still visible today. ${ }^{122}$

The church was originally private, but in 1513 it appears as belonging to a fraternity of donors. ${ }^{23}$ It served as the seat of the protopapas ${ }^{124}$ (the head of the Orthodox clergy) of Corfu until 1712, while it was merged in 1577 with the church of St Lazarus, when the latter was demolished for the needs of the fortification of the town. Since then, it appears in the documents with both names, while the name of St Nicholas gradually prevails. From the 19th century onwards it is mentioned as St Nicholas 'the Old', while today it is known as St Nicholas dei Vecchi. ${ }^{125}$

\footnotetext{
121 Vokotopoulos 1990, 117.

122 Agoropoulou 1976, 282; Gallas 1992, 220.

123 Karydis 2007b, 165; Papageorgiou 1920, 206.

124 About the organisation of the Orthodox Church of Corfu, see p. 5, n. 11 herein.

125 Karydis 2007b, 166; Papageorgiou 1920, 206.
} 


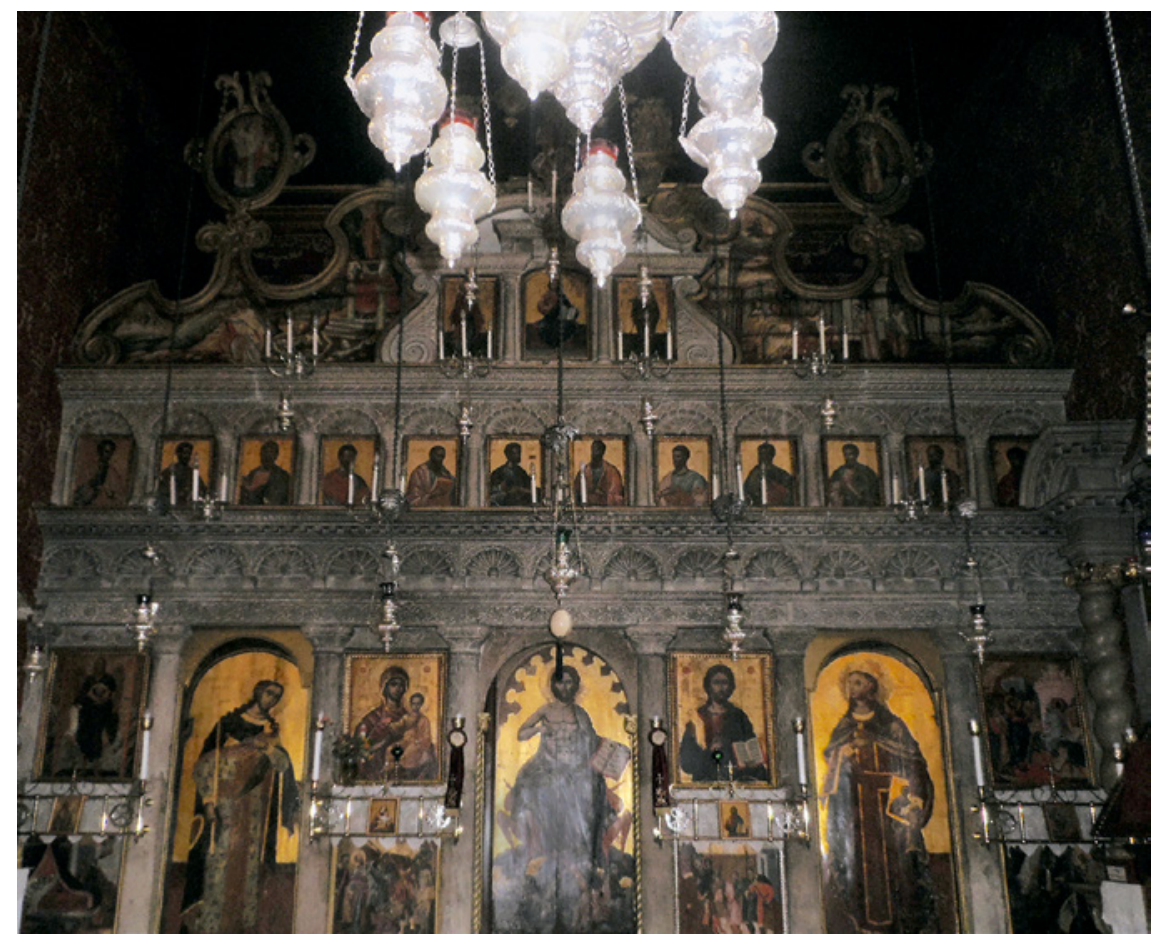

FIGURE 22 Iconostasis of the church of St Nicholas dei Vecchi, Corfu

According to Spyridon Papageorgiou and Athanasios Tsitsas, the relic of St Theodora, probably along with that of St Spyridon, was moved to St Nicholas from the church of St Lazarus around the third quarter of the $15^{\text {th }}$ century. ${ }^{126}$ Three travelogues of the late $15^{\text {th }}$ century, those of Georges Lengherand of Mons (1485-1486), Konrad Grünemberg (1486) and Dietrich von Schachten (1491-1492), support this assertion. Grünemberg reports seeing the relics of Sts Spyridon and Theodora at the church of St Nicholas, although he seems to have misunderstood the name of St Spyridon: 'In a Greek church standing high on a hill, two holy bodies are kept. One is a Greek archbishop called in Greek Spiritiam Palatin Viridus. The other is the daughter of the Emperor Constantine, called Sorora in Greek and Theodora

126 Papageorgiou 1920, 206; Tsitsas 1967, 65. It is worth mentioning that, according to other scholars, the above-mentioned relics were moved from the church of St Athanasius to the church of St Lazarus and from there to the church of Taxiarchis Michael. Nikiforou 2014, 350-357; Pieris 2007, 61-62. 
in Latin.' ${ }^{127}$ In 1491 the German nobleman Dietrich von Schachten also makes mention of two bodies of saints kept in a Greek church in the borgo, but named only one of them, St Theodora. ${ }^{128}$

Georges Lengherand, who visited Corfu in 1485 , provides a quite detailed description. He mentions that the body of St Spyridon was entire and actually 'during his feast day he stands upright', attesting to the first stages of the custom of putting the saint's relic in a vertical position, while he adds the information that it was brought to Corfu from Constantinople. As far as the relic of St Theodora is concerned, he mentions only that it was not preserved in its entirety. Furthermore, obviously not impressed by the reliquaries and the church building, he states that the saintly bodies were very badly kept. ${ }^{129}$

The relics kept and venerated in the church of St Nicholas, the bodies of St Theodora and St Spyridon, both had a long history before arriving on the island of Corfu. They were translated from Constantinople after its fall to the Ottomans and arrived on the island in 1456. The fact that the first mention of these relics dates back to 1485 , only a short period after their appearance on Corfu, is indicative of the fame they were rapidly acquiring. They were relics brought from the lost capital city of the former Byzantine Empire, thus constituting a link with the local population's spiritual metropolis; at the same time, St Spyridon seems to have been a known and highly venerated saint, famous for his miraculous powers, and very quickly overshadowed not only St Theodora, but also the former patron saint of the island, St Arsenius, and even the Serenissima's protector, St Mark. The gradual culmination of the cult of St Spyridon and his elevation to the throne of the sole protector of the island took place in the century after the time frame of this study, and this could be the reason why pilgrims' references to his relic are so few.

127 'Item oben uff aim berg ligt ain kriechische kierch, dä ligend inn zwen hailgen. Ainer ist gesin ain kriechischer ertz bischoff, genempt worden in kriechischer spräch Spiritiam Palatin Viridus. Das ander ist ain tochter gesin Constandtinus des kaisers, haist in kriechischer spräch Sorora, in lattin Theodora.' Denke 2011, 335.

128 'Auch ihnn einer Griechischenn Kierchenn ihnn der Vorstadt liegenn zwene heiligenn gantz ohnversertt, dessgleichenn S. Theodora, wilche das Königreich Neapolis zum christlichenn Glaubenn brachtt hatt.' Röhricht and Meisner 188oa, 179.

129 'En laquelle ville il y a une chappelle de saint Nicolay là u avons veu deux corps saints; assavoir stts Spiridius archiepiscopus de Chipro, et est tout entier, lequel l'on dist que le jour de sa feste il se tient droit et fut apporté de la cité de Constantinoble à la prinse qui par ci devant fut faicte; et l'autre s'appelle sancta Theodora, regina de Cypro, lequel n'est pas tout entier, mais ilz sont pour sains très mal révéramment mis.' Ménilglaise 1861, 95-96. 


\subsubsection{The Relic of St Spyridon}

The patron saint of Corfu, St Spyridon, was born c. 270 in Cyprus. He became bishop of Trimythous around 312, and in 325 he took part in the First Ecumenical Council in Nicaea, where the heresy of Arius was condemned. During his incumbency as a bishop, he acquired great fame among his flock because of his miraculous powers. Many miracles were attributed to him during his lifetime. He died in 348 in Cyprus, where his body was kept and venerated at a church dedicated to him in Trimythous. ${ }^{130}$ His relic was moved to Constantinople at the end of the 7 th century, probably in 691, in order for it to be protected from Arab raids. In Constantinople it was housed in several churches: at the convent of the Theotokos Kecharitomene, the katholikon of the monastery of Odegon and finally at the church of the Holy Apostles, where several Russian travellers report seeing it, among whom Zosima the Deacon (1319-1322), Stefan of Novgorod (1350) and Ignatius of Smolensk (1389). ${ }^{131}$ Already from the 9th and 1oth centuries, St Spyridon's relic was highly venerated in Constantinople and the Greek Orthodox world. ${ }^{132}$ On 12 December 1452, the day of his commemoration, St Spyridon's relic was carried in a procession held in the church of St Sophia to celebrate the union of the churches. ${ }^{133}$ According to the prevailing legend, after the fall of the Byzantine capital to the Ottomans in 1453, a Corfiot priest, Georgios Kalochairetis, carried the relics of Sts Spyridon and Theodora through Epirus to the island of Corfu, where they arrived in $1456 .{ }^{134}$

The relic of St Spyridon appears in several documents soon after its translation to the island of Corfu (already in 1480), mostly concerning its ownership. After what seems to be a long dispute, St Spyridon's relic was acknowledged as the property through inheritance of Georgios Kalochairetis's sons Philipos and Loukas. Other documents, in particular two ducal letters of 1489 , reveal the fact that the new legal owner of the relic, Philipos Kalochairetis, had requested permission from the Venetian Senate to transport it to Venice. In fact, St Spyridon was known to the West already from Late Antiquity, as a participant of the First

130 Tsitsas 1967, 9-19; Metallinos and Dountsi 2007, 19-21; Van den Ven 1953, 143-145; Bakalova and Lazareva 2006, 434-435.

131 Majeska 1984, 194, 94; Tsitsas 1967, 21; Pieris 2007, 62.

132 Tsitsas 1967, 32; Bakalova and Lazareva 2006, 435.

133 Tsitsas 1967, 21; Theodoridis 2007, 31 .

134 The legend is doubted by some scholars, who claim that the relics were transferred to Corfu by the priest Grigoris Polyeuktos, who in turn entrusted them to the care of Georgios Kalochairetis. Voulgaris and Manesis 1857, 4-5; Karydis 2007b, 81; Tsitsas 1967, 21-22; Nikiforou 2014, 349-351; Leontsini 2014, 34; Bakalova and Lazareva 2006, 437. 
Ecumenical Council. ${ }^{135}$ The permission was granted, but St Spyridon never left the island of Corfu. ${ }^{136}$ The reason why the translation of the relics to Venice never took place is unknown. According to Andrea Marmora, it was prevented by the opposition of the Corfiots. ${ }^{137}$ Whatever the case may be, all of the aforementioned factors indicate that very soon after the relics' conveyance to Corfu the cult of St Spyridon was growing increasingly popular.

Since arriving on the island, the relic of St Spyridon was housed in a number of churches before eventually being accommodated in a church dedicated to him, where it remains until today (Fig. 23). ${ }^{138}$ As already mentioned, the relic of St Spyridon, probably along with that of St Theodora, was moved to St Nicholas from the church of St Lazarus around the third quarter of the 15th century. ${ }^{139}$ In 1614 the Italian traveller Pietro della Vale provided a detailed description of the saint's relic: 'Here, the defunct human body is preserved so perfectly, that, in the instance of one in particular, although he lived in the time of the First Council, his flesh appears yet lively and fresh; that of his leg, when touched, rising again from the pressure.'140

No specific information is given about the reliquary of St Spyridon's body during the $15^{\text {th }}$ and 16 th centuries. The aforementioned Georges Lengherand, who saw it in the church of St Nicholas dei Vecchi, stated that both the holy bodies of St Spyridon and St Theodora were very badly kept. ${ }^{141}$ Indirect mentions of a crystal reliquary of the saint come from documents of 1489 , according to which two keys to the sarcophagus were given to the town's bailiff. ${ }^{142}$ In

135 Bakalova and Lazareva 2006, 451.

136 Karydis 2007b, 81-84; Tsitsas 1967, 22; Nikiforou 2014, 350-354.

137 Marmora 1672, book v, 263.

138 At the time of its arrival, in 1456, it was kept in the church of St Athanasius. Some years later it was moved to the church of St Lazarus and in 1489 to the church of Taxiarchis Michael. In 1527 Stamatellos Voulgaris, the owner of the relic at the time, erected a church dedicated to the saint's name and placed it there. In 1537, during the first Ottoman siege of Corfu, St Spyridon's relic was moved to the church of Sts Cosmas and Damian in order to be protected. It was returned to the church of St Spyridon after the end of the siege and remained there until 1577 , when the church was demolished for the fortification of the borgo, and the relic was moved once again, this time to the church of St Nicholas 'ton Xenon'. Finally, near the end of the 16th century it was moved for the last time to a newly erected church dedicated to St Spyridon (the church was completed in 1594, but it was inaugurated in 1589). Papageorgiou 1920, 206; Tsitsas 1967, 65-67; Nikiforou 2014, 351; Pieris 2007, 61-62.

139 Papageorgiou 1920, 206; Tsitsas 1967, 65.

140 Jervis-White 1970, 127.

141 Ménilglaise 1861, 95-96.

142 Nikiforou 2014, 352; Bulgari 1669, 6. 


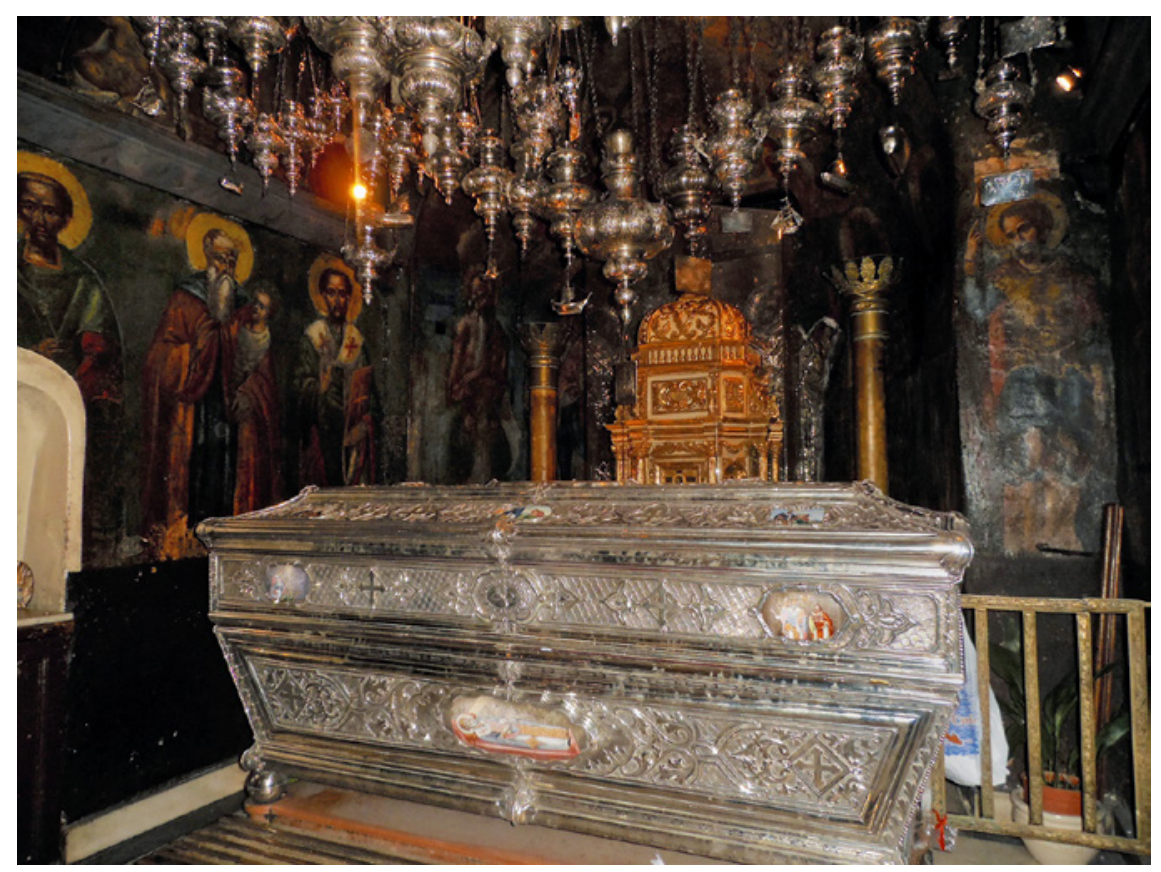

FIGURE 23 St Spyridon's relic in the church of St Spyridon, Corfu

1605 the Cypriot Thomas Motsanega offered the saint a crystal reliquary that was made in Venice. ${ }^{143}$ Today, St Spyridon's relic is kept in a crypt to the right of the sanctuary of the church of St Spyridon in a silver-plated sarcophagus with relief decoration that was made in Vienna in 1867. Inside the sarcophagus there is a smaller gold-plated reliquary with crystal parts through which the relic is visible, made and donated by Markos Cavallis in $1770 .{ }^{144}$

St Spyridon's relic is preserved entire, apart from his right arm, which was separated from the rest of the body. The date of its detachment is uncertain, but a Russian pilgrim who visited Corfu in the $17^{\text {th }}$ century reports that the right arm was missing. ${ }^{145}$ The noble Corfiot Stefanos Mastrakas, who wrote a 'Description of the Island of Corfu' in 1630, mentions seeing the entire body of St Spyridon, deposed at the church bearing his name, with the exception of his right arm, which was kept in Rome. ${ }^{146}$ According to Nikolaos Voulgaris, a

\footnotetext{
143 Tsitsas 1967,52 ; Voulgaris and Manesis $1857,6$.

144 Tsitsas $1967,68$.

145 Tsitsas $1967,21$.

146 Tsitsas $1974,81$.
} 
member of the family who owned the relic and the author of a book concerning its history (1669), the saint's right arm was kept and venerated in Rome, but it is not certain if it arrived there from Corfu, Constantinople or Cyprus. ${ }^{147}$ In 1986 it was brought to Corfu with great celebration.

The cult and the cult practices in relation to St Spyridon's relic started very soon after its translation to the island and became extremely popular. Within a few years St Spyridon had practically replaced, in the conscience of the pious, the old patron saint of Corfu, St Arsenius, whose relic was appropriated by the Latin rulers of the island, as well as St Mark's primacy as a religious point of reference that the Latins had tried hard to inaugurate. Already from the first quarter of the 16th century, miracles started to be attributed to St Spyridon, amplifying the new cult. ${ }^{148}$ It is clear that, at least in its first stages, the founding of St Spyridon's cult derived directly from the faith of the population of the island and not from religious or administrative actors. The island's Venetian authorities handled the growing popularity of the newcomer saint in a way that respected the particularities of the religious equilibrium of the island. From the very beginning of the establishment of the cult, Greeks were allowed to conduct their religious practices in the Orthodox churches where the relic was kept, but very often, and with a range that mounted along with St Spyridon's popularity, the Latins participated in these religious acts. After a certain point, the saint was used by the Venetians, since he became the only non-secular authority to which the island's population in its entirety complied. Already in 165 o St Spyridon is referred to as the protector of the island, while during the 17th century the saint was invoked before the undertaking of any military operation, and his form had replaced St Mark as a figurehead on the Venetian galleys. ${ }^{149}$ The saint's feast was included in the Venetian liturgical calendar as early as 1589 , and his cult spread widely in Venice during the 18 th century. ${ }^{150}$

The relic of St Spyridon was never kept by the Latins. Throughout its history it was the property of the descendants of the man who allegedly brought it

147 Voulgaris 1669, 7; Tsitsas 1967, 21. The saint's arm was kept in the church of Santa Maria in Vallicella, donated by Pope Clement viII to Cardinal Cesare Baronio of the Oratory of St Philip Neri and, according to the 1806 catalogue of the sacristy, came directly from the church of the Holy Apostles of Constantinople. Tsitsas 1967, 24.

148 According to various legends, in 1524 St Spyridon saved the town from famine and in 1629 and 1673 from the plague and in 1537 and 1716 protected the island from the Ottoman attacks. Tsitsas 1967, 50-59; Theodoridis 2007, 33-34; Nikoforou 2014, 359-373.

149 Nikiforou 2014, $35^{8}$.

150 D'Antiga 2009, 111-113. 
from Constantinople, the families of Kalochairetis and later on of Voulgaris, and remained strictly connected to the Orthodox. It is not an uncommon phenomenon in Latin-ruled Greek cities that representatives of both rites performed common liturgies or other religious acts. What is different in this case is the fact that it was not the Latins who allowed the Orthodox to take part in a liturgy or procession related to a relic kept by them, but the other way round. ${ }^{151}$ An analogous policy of the recognition of the veneration and cult of a local patron saint, deriving from the basis of the community and going beyond the religious rituals and into civic ceremonies and relations, can be seen in the appropriation of the Venetian authorities of the existing cult of Corfu's former patron saint, St Arsenius, as well as on Crete with the cult of its patron saint, St Titus. ${ }^{152}$

The cult of St Spyridon remains to today very strong on the island of Corfu. Most of the liturgical habits established during the Venetian occupation of the island are still performed in the same way.

\subsubsection{Liturgical Habits}

The treatment of the liturgical practices related to the relic of St Spyridon is beyond the interest of this study, since it flourished after the 16th century. The cultic phenomena described here are all connected to the relic of Corfu's new patron saint and not necessarily to the church that seems to have housed it for a period of time, St Nicholas dei Vecchi. In particular, the only practice that seems to have actually taken place in that church is the veneration or procession of the relic in a standing position on the day of the commemoration of the saint's death, as mentioned by the pilgrim Georges Lengherand of Mons. The rest of the processions, with the exception of the one on Holy Saturday, were established after the saint's relic had been transferred to the church bearing his name, where it is still kept today.

Since its translation from Constantinople in 1456, St Spyridon's relic became extremely popular among the Orthodox population of the island. More and more miracles started being attributed to the saint, and his cult grew rapidly. The first miracle that, according to tradition, was performed by the saint was in 1524, when he saved the town from famine. From then on, many more miracles were attributed to him, among which four stood out and occasioned the establishment of processions of the saint's relic that are carried out to this day. Needless

\footnotetext{
151 About analogous phenomena - the embracing by the Latins of a local cult in Orthodox rite churches - in Cyprus, see Olympios 2013, 329.

$15^{2}$ Georgopoulou 1995, 486.
} 
to say, impromptu processions were also carried out for such exigencies as earthquakes, famine, inclement weather conditions, Ottoman threats and so on.

The four miracles performed by the saint initiated the institution of the four main annual processions of his relic. The oldest known litany was the one performed every Holy Saturday: the saint's sarcophagus was opened, and his relic displayed for public veneration for a period of four days, from Holy Saturday to Bright Tuesday. The actual date of the establishment of the Holy Saturday procession is unknown, but, according to tradition, it was distinguished as a remembrance of the rescue of the island from famine at some point before $1553 .{ }^{153}$ The other three litanies of the saint's relic were instituted in the 17th and 18th centuries and are therefore outside of the time frame of this study. 154

Besides the litanies, two times a year, once at Easter and once on the day of the commemoration of the saint's death, St Spyridon's relic was taken out of its reliquary and was placed for three days for public veneration in a standing position at the right-hand door of the tripartite sanctuary of the church. ${ }^{155}$ The saint's body was also processed in a standing position, as is still done to this day. ${ }^{156}$ This practice of carrying the saint's body in a standing position is attested to in archival documents and depictions in icons and engravings, as well as in the travelogue of the pilgrim Georges Lengherand (1485-1486), who

153 Tsitsas 1967, 53; Nikiforou 2014, 361; Theodoridis 2007, 33 .

154 The second litany of the saint's relic was established by the Venetian authorities in 1630, after the attribution to St Spyridon of the miracle of saving the town from the plague in 1629. This litany, performed to this day, takes place every Palm Sunday. Another miraculous intervention of St Spyridon, again to save the island from a great epidemic in 1673, was celebrated by a procession of his relic every first Sunday of November. Maybe the most important and certainly the biggest procession of St Spyridon's relic is the one on 11 August. It was established right after the Ottoman siege of 1716, which ended favourably for the Venetians, by the supreme representative (capitaneus) of the island at the time, Andrea Pisani. About the litany of Palm Sunday, see Tsitsas 1967, 54; Nikiforou 2014, 360; Theodoridis 2007, 33. About the litany in November, see Tsitsas 1967, 54; Nikiforou 2014, 361-363; Theodoridis 2007, 33. About the litany in August, see Tsitsas 1967, 59-6o; Nikiforou 2014, 363-366, 372; Theodoridis 2007, 33 .

155 An analogous custom can also be seen in Zante (Zakynthos) in relation to the relic of the island's patron saint, St Dionysius. The saint's relic is still venerated and carried in processions in a vertical reliquary. Even before it was transferred to Zante, when it was kept in the monastery of Strophades the relic was placed in a vertical position, 'sitting at the episcopal throne' (assiso in Trono Episcopale). Ferrari 1723, 203; Tsitsas 1967, 27; Nikiforou 2014, 359; Theodoridis 2007, 33; Bakalova and Lazareva 2006, 439-442.

156 Until 1605 St Spyridon's body was carried in the hands of the protopapas and since then in a gold-plated crystal vertical reliquary made in Venice, donated by Thomas Motsanega. Tsitsas 1967, 52; Voulgaris and Manesis 1857, 6; Tsitsas 1974, 82. 


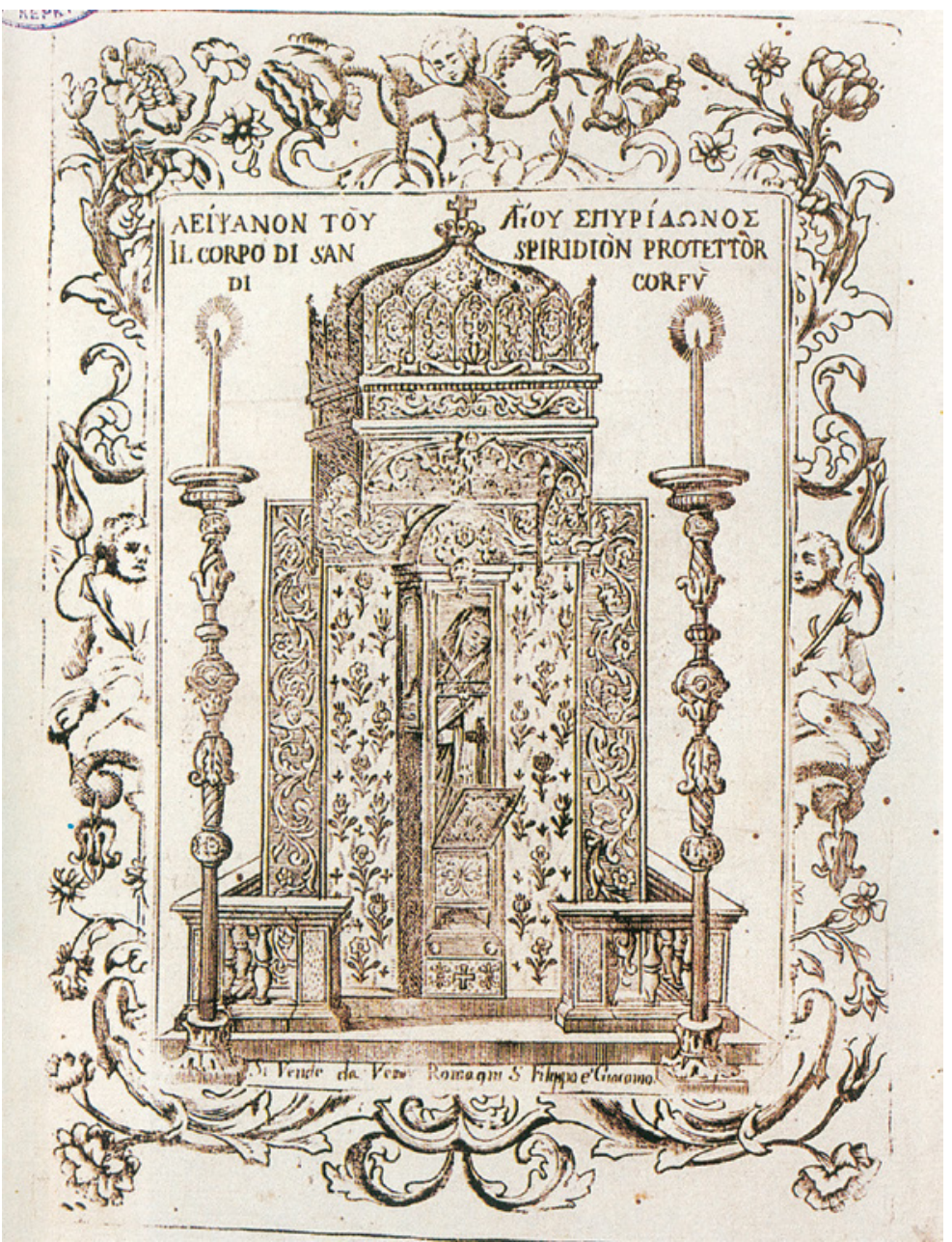

FIGURE 24 St Spyridon's relic displayed in a standing position, engraving

mentions that the body of St Spyridon is displayed standing upright on his feast day, thus indicating that the placing or carrying of the saint's relic in a vertical position was practised already from the end of the 15 th century (Fig. 24 ). ${ }^{157}$ In 1630 the local nobleman Stefanos Mastrakas verifies this custom, stating that St Spyridon 'because of his exceptional grace stands on his feet'. 158

\footnotetext{
157 Bakalova and Lazareva 2006, 439-442; Bitha 1995, 151-168; Bitha 1997, 251-284; Ménilglaise 1861, 95 .

158 Tsitsas 1974, 82.
} 
Gradually, religious events of the regular ceremonial acts of the Orthodox Church, such as the litany of the Holy Cross or the water consecration during the feast day of the Epiphany, were performed at the church dedicated to St Spyridon. By the 17th century, almost 15 o years after the translation of the saint's relic to Corfu, at least half of the annual litanies of the Orthodox took place in his church. ${ }^{159}$

\subsubsection{The Relic of St Theodora}

St Theodora was born in Ebissa in Paphlagonia in 815 and was probably of Armenian origin. After the death of her husband, the iconoclast emperor Theophilos, in 842 she ruled in his name until 856. During her reign she restored the icons at an ecclesiastical council in March of 843 with the help and support of Methodios, later Patriarch of Constantinople. She died in 867, but she was so highly venerated by later generations that she was canonised by the church for restoring Orthodoxy. 160

According to the prevailing legend, St Theodora's relic was transferred to Corfu from Constantinople along with that of St Spyridon in $1456 .{ }^{161}$ At the time of its arrival on the island of Corfu, St Theodora's relic was deposed at the church of St Athanasius, while some years later it was moved to the church of St Lazarus, where it remained until 1577, when the church was demolished for the borgo fortification works; or, according to other scholars, it was moved to the church of St Nicholas from the church of St Lazarus around the third quarter of the 15th century. ${ }^{162}$ After that, in March 1725 , St Theodora's relic was transferred to the church of Taxiarchis Michael and finally to the metropolitan church of the Virgin Spilaiotissa and St Blaise, where it remains to this day (Fig. 25). ${ }^{163}$ The assertion that St Theodora's and St Spyridon's relics were kept for a period of time in the church of St Nicholas can be supported by the three pilgrims' reports from the late $15^{\text {th }}$ century. ${ }^{164}$ Another testimony of the presence of St Theodora's body in the church of St Nicholas comes from the aforementioned Stefanos Mastrakas, who states that the holy relic of St Theodora was kept and venerated in a silver sarcophagus at the church of St Nicholas. ${ }^{165}$

\footnotetext{
159 Nikiforou 2014, 371.

160 Garland 1999, 95-96.

161 Voulgaris and Manesis 1857, 4-5; Karydis 2007b, 81; Tsitsas 1967, 21-22; Nikiforou 2014, 349, 351; Leontsini 2014, 34.

162 Papageorgiou 1920, 206; Tsitsas 1967, 65; Nikiforou 2014, 350-357; Pieris 2007, 61-62.

163 Papageorgiou 1920, 201, 203, 206, 210; Tsitsas 1967, 65 .

164 See pp. $55^{-} 5^{6}$ herein.

165 Tsitsas 1974,83 .
} 


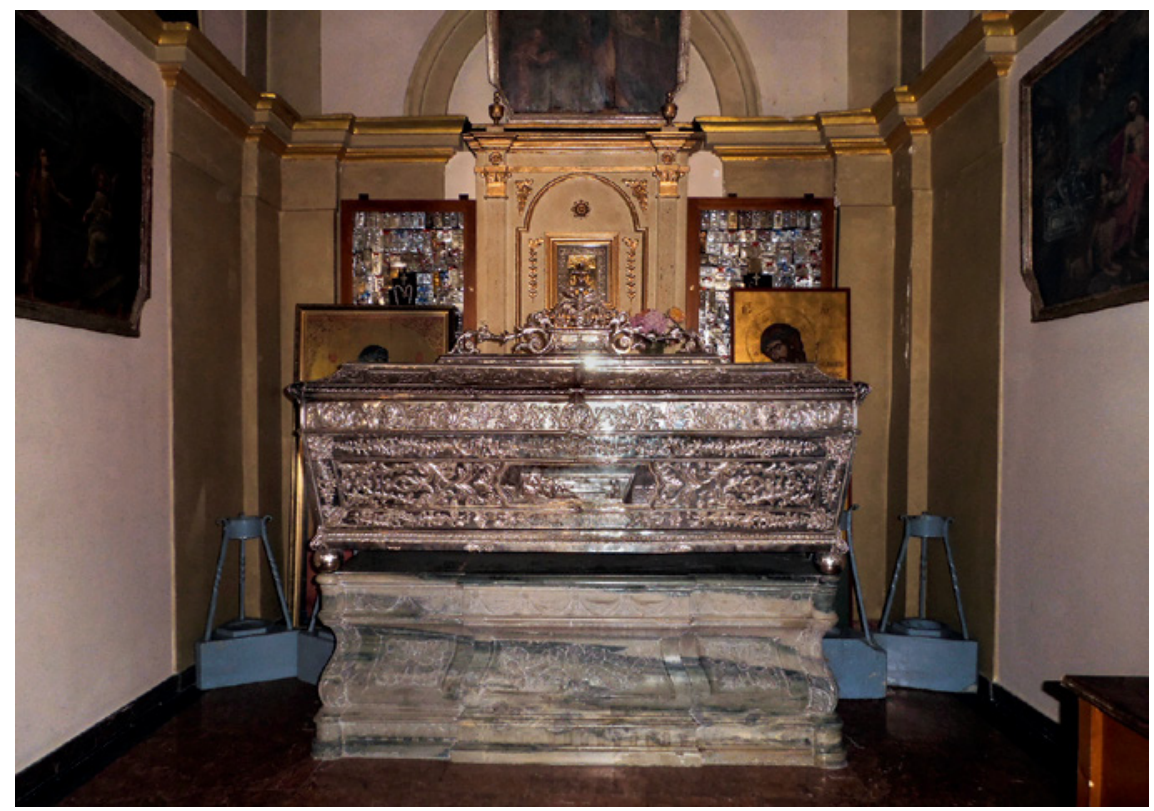

FIGURE 25 St Theodora's relic in the Orthodox cathedral of the Virgin Spilaiotissa and St Blaise, Corfu

As mentioned by the pilgrim Georges Lengherand, St Theodora's relic is not entire. ${ }^{166}$ The head is not preserved, and in its place there is a skull that probably does not belong to the preserved body. The rest of the saint's body is complete, with the exception of the right leg from the knee down, as well as one finger of the right hand. ${ }^{167}$ Just like the relic of St Spyridon, St Theodora's one was inherited by the descendants of the family of the priest who allegedly brought it from Constantinople, Georgios Kalochairetis, and in particular by his son Markos, who in 1483 donated it to the community of Corfu. ${ }^{168}$

No information survives about the reliquary of St Theodora's body during the $15^{\text {th }}$ or 16 th centuries. Today, the saint's body is kept, as mentioned above, in the metropolitan church of the Virgin Spilaiotissa in an elaborate silver-plated repoussé sarcophagus of 1868 .

St Theodora's cult did not develop in Corfu. From the time of the arrival of her relic on the island, she was considered of minor importance and was completely overshadowed by St Spyridon. This is probably the reason why her relic

166 See n. 129 above.

167 Papageorgiou 1920, 110.

168 Karydis 2007b, 81-84; Tsitsas 1967, 22, Nikiforou 2014, 350-354. 
was not moved along with the ones of the new patron saint to a Community church, but remained instead in the small church of St Lazarus. No ceremonies or processions related to her relic are attested during the Venetian period of Corfu.

\subsection{The Franciscan Monastery of St Francis}

As far as the Latin churches and monasteries of Corfu that are mentioned in the travelogues are concerned, the numbers of both religious institutions and references to them are very low. On the other hand, one should take into consideration that during the examined period only nine Latin churches and monasteries were officiating on the island. In fact, it is not absolutely certain that even these churches were all continuously officiating throughout the 14 th to the 16 th centuries. According to a document of 1406, the Augustinian monastery of the Annunziata was at the time the only Latin religious centre on the island, while in the 16th century two of the nine Latin churches of the town appear to have been abandoned. ${ }^{169}$ In addition, the buildings of the these institutions were definitely much less elaborate than the ones the pilgrims had already seen during their stay in Venice, as well as in the major cities on the Dalmatian coast, and, most importantly, none of them possessed relics that could attract pilgrims' interest and attention to act as agents of anticipation of the religious experience they were expecting to have in Jerusalem. ${ }^{170}$ With that in mind, the references to the three of them mentioned in the travelogues, that is, the Franciscan and Augustinian monasteries and the Latin cathedral of Sts Peter and Paul, may be few, but provide valuable information.

The Franciscan monastery of St Francis is the religious institution that amasses the largest number of references compared to any other church or monastery in the town of Corfu (Fig. 26). ${ }^{171}$ Its inauguration coincided with the rendering of Corfu to its new Venetian rulers on 20 May 1386, so it was in a way inextricably linked to the island's history and at the same time one of the oldest non-Orthodox institutions of the town. Every year, on the

169 Agoropoulou 2004, 232, 238; Sathas 1880-1883, vol. 2, 141; Karydis 2007a, 241-242; Karapidakis 1998, 144.

170 The relics of the island's patron saint, St Arsenius, which were housed in the cathedral of the island, were not of significant importance to a Western traveller. Actually, St Arsenius was most probably unknown to them, judging by the misspelling of his name in some of the few travelogues that mention him. As far as the monasteries of the Augustinians and Franciscans are concerned, neither of them seems to have possessed any relics during the examined period, as deduced from pilgrims' narratives and archival and archaeological evidence.

171 About the religious orders in Greece, see indicatively Tsougarakis 2012; and in particular about the Ionian Islands, see Tsougarakis 2012, 275-310; Pagratis 1999. 


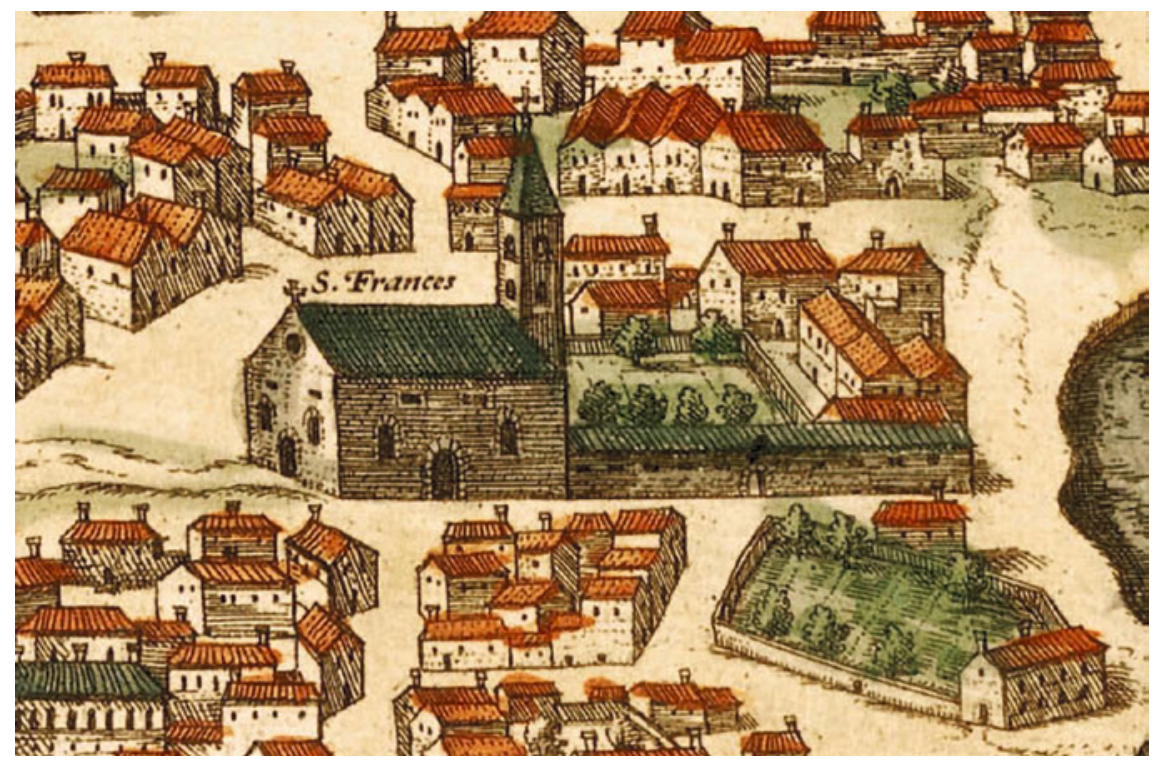

FIGURE 26 The Franciscan monastery of Corfu, c. 1575. Detail of Fig. 15

anniversary of Corfu's rendering, a date that coincided with the commemoration of St Bernardine of Siena, a ceremony was held and included a procession starting from the cathedral and leading to St Francis, with the participation of secular as well as religious representatives of both rites. ${ }^{172}$

The precise date of the monastery's construction is uncertain. In his book Della historia di Corfu, Andrea Marmora mentions two traditions concerning the establishment of the monastery of St Francis. According to the first, during the period when Corfu was subject to the Despotate of Epirus (12141251), a church dedicated to St Angelos was built and later on constituted the katholikon of an Orthodox convent, which was abandoned or abolished by the Angevins, who took over the island in 1267. This convent was then renovated to meet Western standards and granted to the Franciscans by Philip, Duke of Tarrant, in 1367. It was in that monastery that the ceremony of the symbolic rendering of the key of the town of Corfu to its new Venetian rulers, represented by Admiral Giovanni Miani, took place on 20 May 1386. In memory of that event an inscribed marble plaque was embedded in the façade of the building. ${ }^{173}$ According to the other tradition, this ceremony took place at

172 Nikiforou 2014, 56; Tsitsas 1969, 157-158.

173 This plaque was destroyed in the 19th century. Agoropoulou 2004, 232; Gaoutsis 2001, 324; Karydis 2007a, 240-241. 
the church of St Angelos, which was inaugurated on the same day. ${ }^{174}$ This second tradition seems more unlikely, since the church that Marmora mentions was later on quite safely identified as the church of Taxiarchis Michael in the Campiello district. ${ }^{175}$

The date of the renaming of the monastery is also uncertain. Up until the 16th century both names appear in the documents, while the surrounding area was called 'Santangelo', 'contrada di San Francesco' or 'calle larga di San Francesco'. The name St Francis prevailed after the first half of the 16th century, but in many cases it was followed by the phrase 'olim Sant' Angelo'.176

Whatever may be the case, no traces that could justify the monastery's dating to the 13th century survive to this day. The monastery is known to have had suffered severe damage during the Ottoman siege of 1571 and obtained its final and present form after a complete renovation in 1621, when it was also consecrated by Archbishop Benedetto Bragadin. ${ }^{177}$

The conventual church followed the most popular architectural type of the churches, both Latin and Orthodox, of the Ionian Islands: a one-aisled, wooden-roofed basilica, in this case with a particularly long aisle $(27.80 \mathrm{o} 8.40 \mathrm{~m})$ and entrances at the west and the south. Two tall arched windows opened on both sides of the main south entrance and two other semi-circular windows on the west wall (Fig. 27). Located between the niche of the sanctuary and the chapel to its south is a voluminous bell tower. The sanctuary is slightly elevated and tripartite. It is separated from the aisle by a marble parapet. The main altar, made of white marble, is of simple form and stands on a base elevated by three steps in the middle of the sanctuary, occupying most of its breadth. The two lateral parts of the sanctuary, separated by double arches, lead to the courtyard and the building complex of the priory and the chapel of St Anna and the bell tower, respectively. On the west side of the church there is a small portico for the organ. Near the south entrance, two small basins are embedded in the wall, one of which bears the blazon of the Franciscans and the date 1571, probably related to the restoration of the monastery after the Ottoman siege. ${ }^{178}$

Inside the church, besides the central altar dedicated to St Francis, there are four lateral ones: three dating to the 18th century, dedicated to the Virgin, St Anthony and St Barbara, and a 19th-century one, dedicated to St Rocco

\footnotetext{
174 Agoropoulou 2004, 232; Pagratis 1999, 117; Marmora 1672, book V, 232-233.

175 Papageorgiou 1920, 200-201; Agoropoulou 2004, 232; Pagratis 1999, 117.

176 Agoropoulou 2004, 232; Pagratis 1999, 118-119; Karydis 2007a, 240-241.

177 Agoropoulou 2004, 233; Gaoutsis 2001, 323; Giotopoulou 1997, 70.

${ }_{17} 8$ Agoropoulou 2004, 234.
} 


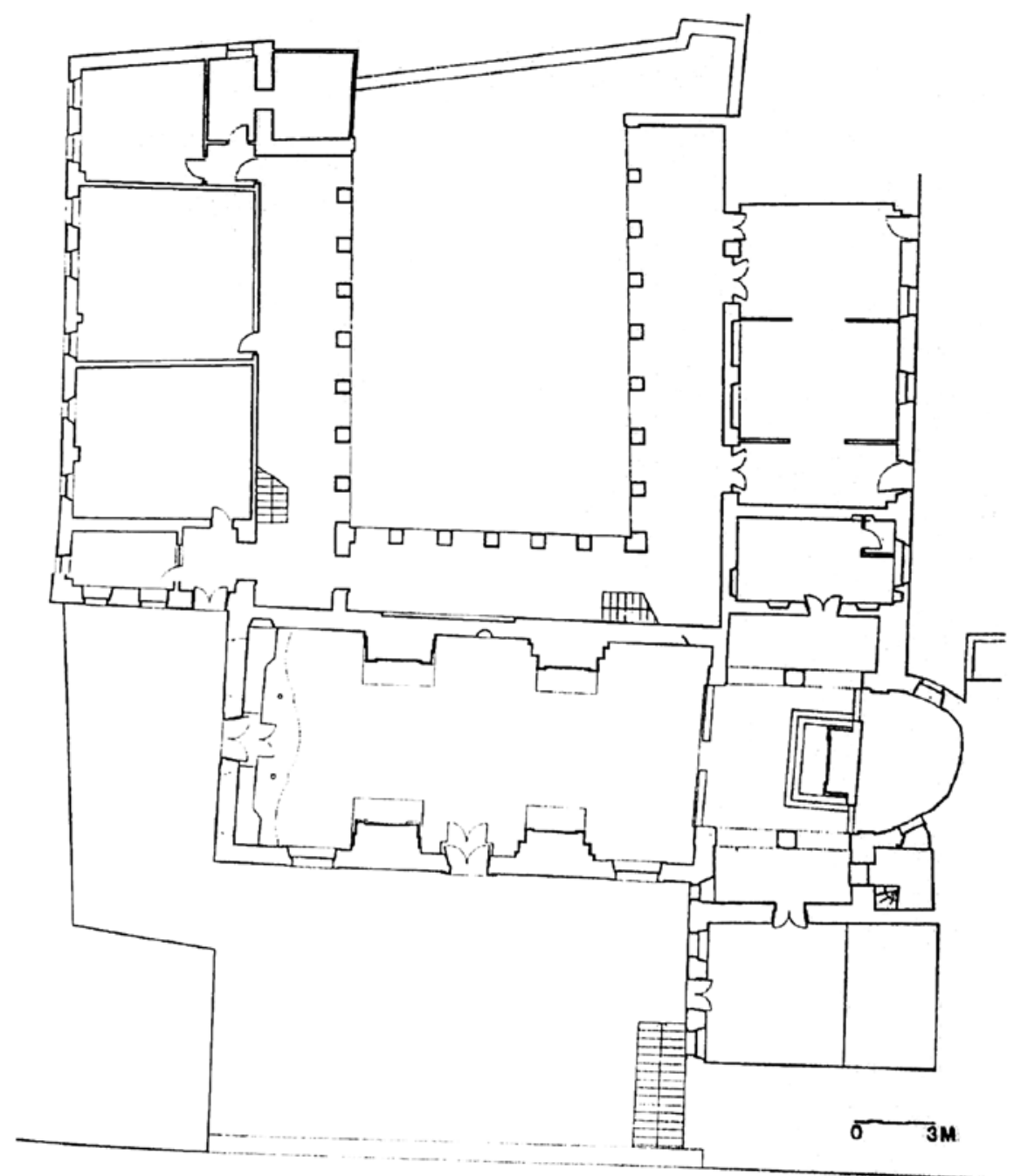

FIGURE 27 Plan of the Franciscan monastery of Corfu

(Fig. 28). ${ }^{179}$ The flooring of the building has now been largely replaced with modern tiles, but some inscribed burial plaques dating to the 17th and 18th

179 The altar of St Barbara, located in the west part of the north wall, was made in 1739 of white marble and belonged to the guild of cannoneers. The icon of the saint is a work by Francesco Fontebasso, an 18th-century Italian artist known from his works in Venetian churches. The second altar, also on the north wall, dedicated to St Anthony and built in 


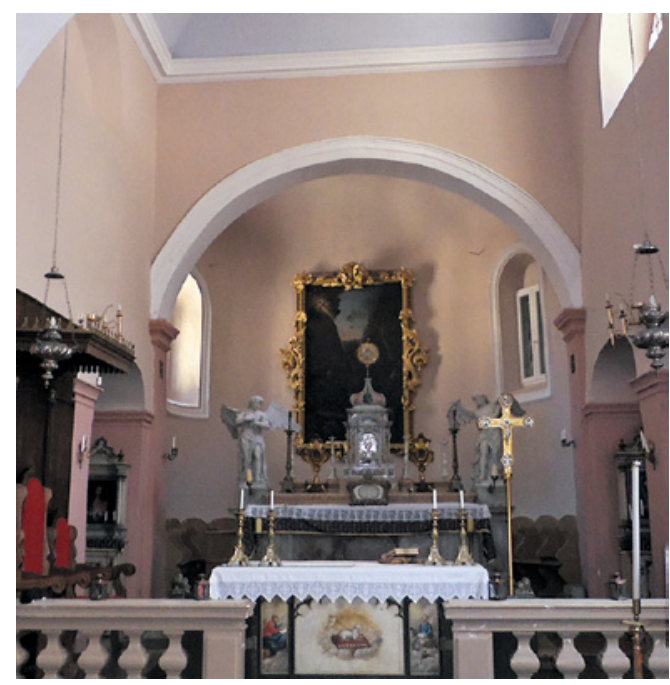

FIGURE 28 The central altar in the church of St Francis, Corfu

centuries remain in situ or in second use; these mark the tombs of soldiers, noble families and members of the fraternities of Sts Jacob and Christopher. ${ }^{180}$

Adjoining the church on its south side is the chapel of St Anna (Fig. 29). It is considered to be the oldest building of the complex, and some identify it as the 13th-century church of St Angelo. It is of a simple rectangular shape and obtained its present form, which bears Gothic elements, after its restoration in 1850, when it was used by the British army. ${ }^{181}$ On a level lower than the church, the building complex of the priory was built in a typical Western manner: a courtyard surrounded on its three sides by a two-storey building with a portico on the ground level. ${ }^{182}$

During the period of the Venetian occupation of Corfu, the Franciscan monastery served as the seat of the chief of the province of Romania, housing a number of postulant monks for one or more years until they obtained their monastic

1751, is more elaborate, adorned with pillars of red marble and embedded with marble plaques on the front and statues along the top. The altar of St Rocco, patron saint of porters, located on the west part of the south wall, is the only wooden one. It was built by the guild in 1821 and is practically a wooden copy of the altar of St Barbara. Its icon, on the other hand, is very old and comes from the church of St Rocco that was destroyed in the 17th century. The fourth altar, located on the east part of the south wall, is dedicated to the Virgin. Dating from the 18th century, it has a form similar to the altar of St Anthony. Agoropoulou 2004, 233-234; Gaoutsis 2001, 324. Agoropoulou 2004, 234.

181 Agoropoulou 2004, 234; Pagratis 1999, 337.

182 Agoropoulou 2004, 233-234; Gaoutsis 2001, 324. 


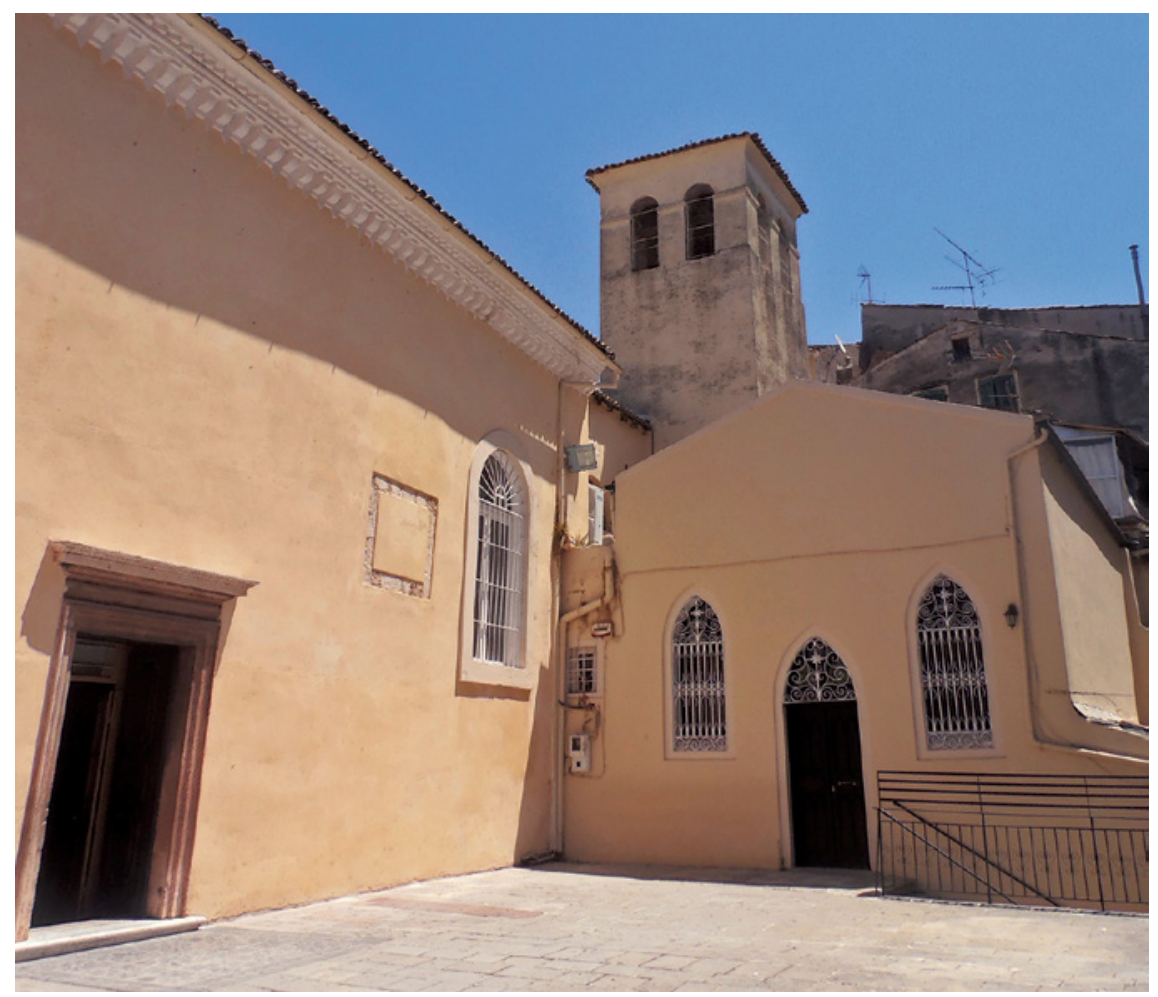

FIGURE 29 The church of St Francis and the chapel of St Anna, Corfu

habit and were sent to their appointed seats. ${ }^{183}$ Also, as in the case of all the Franciscan monasteries of the Ionian Islands, the priory hosted the preachers (predicatori) who visited the island before the periods of fasting for Christmas and Easter, several Italian missionaries who officiated in the Latin churches and covered the needs of the religious institutions of the town as confessors, preachers and catechists, and priests on the Venetian galleys. ${ }^{184}$

When the French occupied Corfu in 1797, the Franciscan monastery was abolished, and its property was confiscated. It then served many different purposes, including housing a school and a printing house. ${ }^{185}$ During World War II it housed the relics and reliquaries of the cathedral of St Jacob, which was

183 Provinces are territorial divisions of the mendicant orders. The Franciscan Order's province of Romania (roughly corresponding to the Empire of Romania) was created in 1263 and was subsequently divided into three custodies: Negroponte (including Euboea, Crete and the Aegean islands), Thebes (including Thebes, Athens and Corinth) and Glarentza (including Achaia and the Ionian Islands). See Tsougarakis 2012, 105, nn. $3^{-4}$.

184 Pagratis 1999, 121.

185 Agoropoulou 2004, 237; Pagratis 1999, 129. 


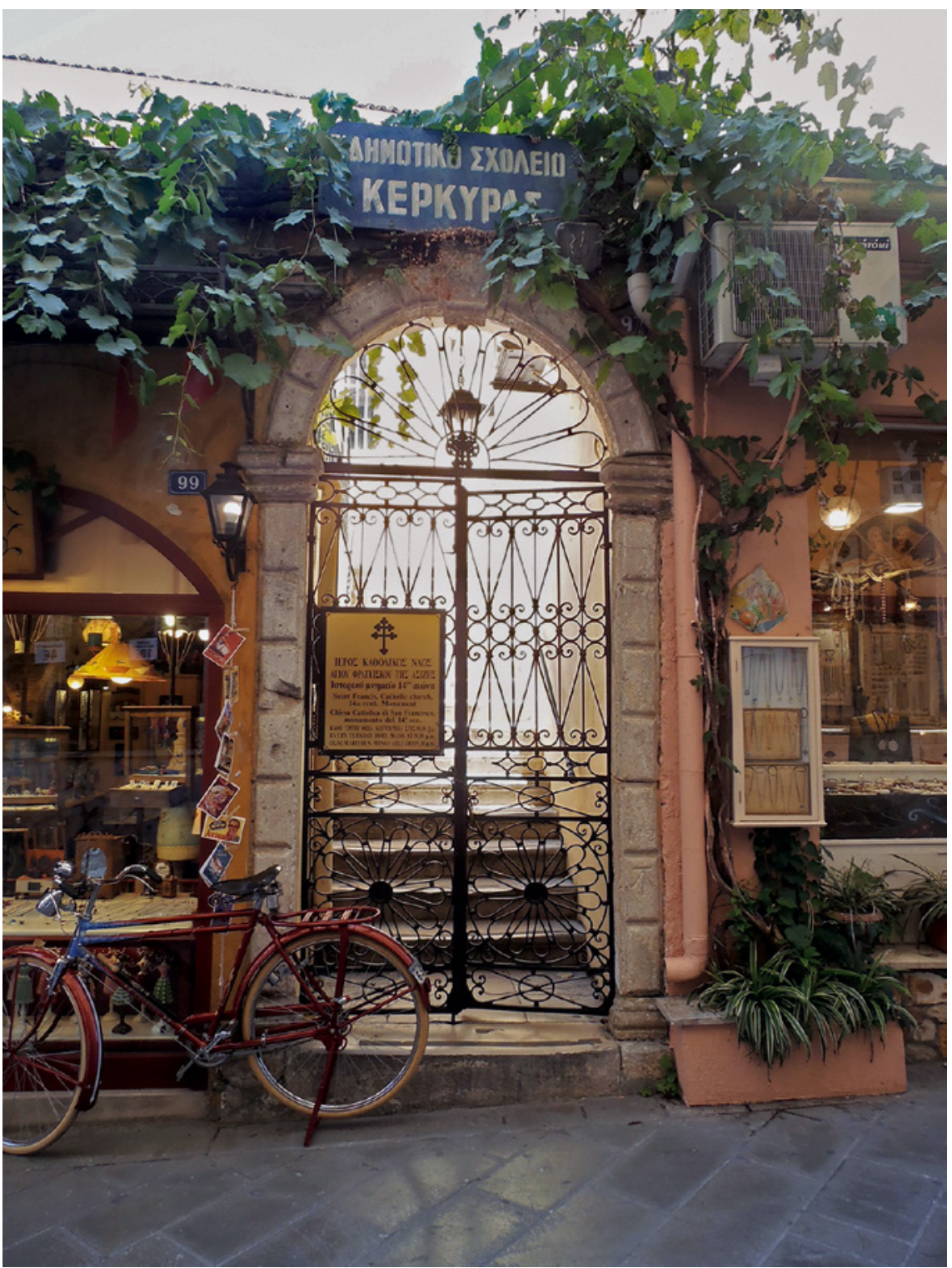

FIGURE 30 The conventual buildings of the monastery of St Francis, Corfu, accommodate an elementary school

destroyed by German bombings, and served for a while as the Latin cathedral. ${ }^{186}$ Today the priory's buildings accommodate a public school (Fig. 30). The church

186 The full list of relics that ended up in the church of St Francis is published in Gaoutsis 1999, 63-73. 
of St Francis still stands in the city of Corfu, attracting many visitors, while liturgies are performed on quite a regular basis.

As mentioned above, the date of the monastery's construction is uncertain. The Franciscan Conventual friar Vincenzo Mutio from Bergamo, chief of the province of Romania, connects its construction with St Francis of Assisi himself, while in 1334 the monastery of Corfu appears in the catalogue of priories of the province of Romania, although this is considered to be a confusion between the towns of Corfu and Coron (present-day Koroni). ${ }^{187}$ The monastery is not included in the catalogue of 1390 and neither is it mentioned in 1406, when, according to a document of that year, the only Latin religious centre of the island was the Augustinian monastery of the Annunziata. ${ }^{188}$ The absence of the Franciscan priory of Corfu from the above-mentioned catalogues does not necessarily mean that it did not exist; it could be explained by the fact that the monastery was in a bad state and temporarily not open to the public. In this case, a few Franciscan friars would have been officiating at the church and probably running the guest houses that existed during that period on the island for the indigent and the travellers. ${ }^{189}$ The existence of the priory of St Francis is attested with certainty in 1482, when the Conventual friar Paul Walther Guglingen visited the Latin monasteries of Corfu and reported that St Francis was in a poor condition with very few monks. ${ }^{190}$

Travelogues prove to be a valuable source of information concerning this gap in the appearance of the monastery in the catalogues, since eight pilgrims who visited Corfu during the period between 1413 and 1482 reported visiting the monastery, while some of them resided there during their stay on the island. ${ }^{191}$ The first to mention the priory is the Italian pilgrim Luchino del Campo in 1413, clearly stating that at least the priory's church was functioning at the time, while just over 6o years later Wilhelm Tzewers (1477-1478) mentioned that the monastery offered accommodation, but was very poor. ${ }^{192}$ The German nobleman Hans Tucher (1479-1480) characterised it as the best in town when

\footnotetext{
187 Pagratis 1999, 119; Moorman 1983, 148.

188 Agoropoulou 2004, 232; Pagratis 1999, 119; Asonitis 1988, 69.

189 Agoropoulou 2004, 232; Pagratis 1999, 119.

190 Agoropoulou 2004, 232; Pagratis 1999, 119; Moorman 1983, 148.

191 The pilgrims Luchino del Campo (1413), Wilhelm Tzewers (1477-1478), Hans Tucher (14771480), Pierre Barbatre (1480), Felix Fabri (1480, 1483-1484), Paul Walther Guglingen (14811483), Jan Aerts (1481-1484) and an anonymous pilgrim (1480) mention the Franciscan monastery of Corfu. Brandoli 2011, 43; Hartmann 2004, 97; Herz 2002, 358; 43; Pinzuti and Tucoo-Chala 1972-1973, 118; Hassler 1843-1849, vol. 3, 348; Sollweck 1892, 78; Van Nispen 1652, Cap. XXII; Schefer 1882 (1970), 43.

192 Luchino del Campo (1413): '[...] e insieme andorno alla chiesia di S. Francesco ad oddire la messa'. Brandoli 2011, 43. Wilhelm Tzewers (1477-1478): 'Hospicia dant peregrinis Augustinenses et Minores, qui sunt valde pauperes.' Hartmann 2004, 96.
} 
it comes to accommodation, an opinion shared by other pilgrims. ${ }^{193}$ Paul Walther Guglingen's description of the monastery conveys important information, being the only one to provide hints of its interior decoration:

In Corfu there are Augustinians, preachers and Minor friars, but none of their monasteries is reformed; they officiate following the Greek rite. The monastery of the Friars Minor is completely abandoned, both in the matters of the church as well as in the other domestic matters [...] we left the galley and entered the monastery; there I officiated mass, and the prince was present with his entourage [...]. In it the nobles ordinarily place their coats of arms, and there are many excellent coats of arms hanging from the walls, engraved on the seats, etc. ${ }^{194}$

In regard to the way the liturgies were performed in the church of St Francis, and unlike the attestation of the Franciscan friar, an anonymous pilgrim who visited Corfu two years before Paul Walther Guglingen, as well as the Norman nobleman Greffin Affagart, who travelled in the 16th century, testify that besides the cathedral the Franciscan monastery was the only place one could attend a Latin mass. ${ }^{195}$ None of the pilgrims visiting St Francis reported seeing any relic, reliquary or cultic object in the church. The oldest attestation of a relic in the monastery is in 1678 , when Marcus Antonius Barbarigo, Bishop of Corfu (1678-1688), brought with him a fragment of the relic of St Francis Xavier. ${ }^{196}$

The amount and value of the information conveyed by pilgrims' narratives concerning the Franciscan monastery of Corfu, despite the relatively small

193 '[...] der peste gemach'. Herz 2002, $35^{8}$.

194 The Franciscan friar's full description is as follows: 'In Corffu sunt Augustinenses Predicatores et Minores; sed nullum monasterium eorum est reformatum; faciunt officia eorum secundum Grecos. Monasterium Minorum totaliter est desolatum, quam in rebus ecclesie quam aliis domesticis, attamen peregrini intrant cum patronis. Et mane feria tertia post Johannis [25 Juni] exivimus galeam et intravimus monasterium; ibi perfeci missam, et princeps cum suis aderat et aluit nos illo die cum ceteris pretiose. Ibi ponunt nobiles arma eorum communiter, et ibi inveniuntnr multa arma bona nobilium pendicta ad parietes, incisa ud sedilia etc.' Sollweck 1892, 78 .

195 Anonymous (1480): 'Il y a environ dix huyt ou vingt eglises èsquelles tout le service se dit en grec, excepté les Cordelliers qui sont latins en l'eglise cathedralle en laquelle on chante aulcunes fois grec et aulcunes foys latin.' Schefer 1882 (1970), 43-44. Greffin Affagart (1519, 1533-1534): 'A Corphou y a bien vingt églises, mays partout l'office se faict selon la secte grecque, excepté à ung couvent des Cordeliers.' Chavanon 1902, 31.

196 Gaoutsis 1999, 67. 
number and the limited length of their references, is of significant importance. They testify to the priory's existence and activity, as well as its importance among the other religious institutions in the town, throughout the 14th to the 16th centuries and especially for a period of almost 70 years (1413-1482) about which no other written testimonies survive. Carefully reading the travelogues, the active presence of the Franciscan friars on a religious as well as a social level in Corfu becomes obvious, and, at least from the pilgrims' point of view, the Franciscan monastery stands out as the most mention-worthy religious centre of the town, as well as the place where the majority of them resided during their stay: 'At Corfu there is a small monastery of the Latin Friars Minor, where we retired, and it was a great relief.' ${ }^{197}$

\subsection{The Augustinian Monastery of St Mary of the Annunciation}

Oddly enough, the other monastery of the mendicant orders of Corfu, the Augustinian monastery of St Mary of the Annunciation, or the Annunziata, which according to an official document of 1406 was at the time the only Latin religious centre on the island, appears sparsely in the travelogues (Fig. 31). ${ }^{198}$ References to it cover a small period of just ten years, from 1477 to 1486, and the monastery of the Annunziata is always mentioned along with the Franciscan priory.

The Augustinian priory was also located in the borgo and was built in 1393, before its fortification. ${ }^{199}$ The land where it was built, as well as the expenses of its construction, was donated by Petro Capese, a feudal lord of Corfu and one of the main negotiators of the subjection of the island to the Venetians. ${ }^{200}$

The monastery's inauguration, on 7 January 1394, turned out to be a huge public event for the island of Corfu. The document of its concession to the Augustinian friars reports that at the celebration both the Latin and Orthodox clergies participated, represented by the Latin Bishop Michael Albano and the Greek Protopapas Elias Monomachos, along with the town's bailiff, Venetian and Greek nobles and a large number of people. ${ }^{201}$ Within the next few years the monastery became the most important Latin religious institution of the island. It had significant property, which was augmented over the years

197 Antoine Regnault (1549): 'Audict lieu de Corfou y a un petit Couuent de freres mineurs Latins, où nous nous allons retirer, qui est vn soulagement.' Regnault 1573, 21.

198 Agoropoulou 2004, 232; Pagratis 1999, 119; Asonitis 1988, 69.

199 Agoropoulou 2004, 230; Giotopoulou 1997, 70.

200 Agoropoulou 2004, 238; Asonitis 1988, 68-69; Karydis 2007a, 241.

201 Asonitis 1988, 69; Tsougarakis 2012, 252-253. 


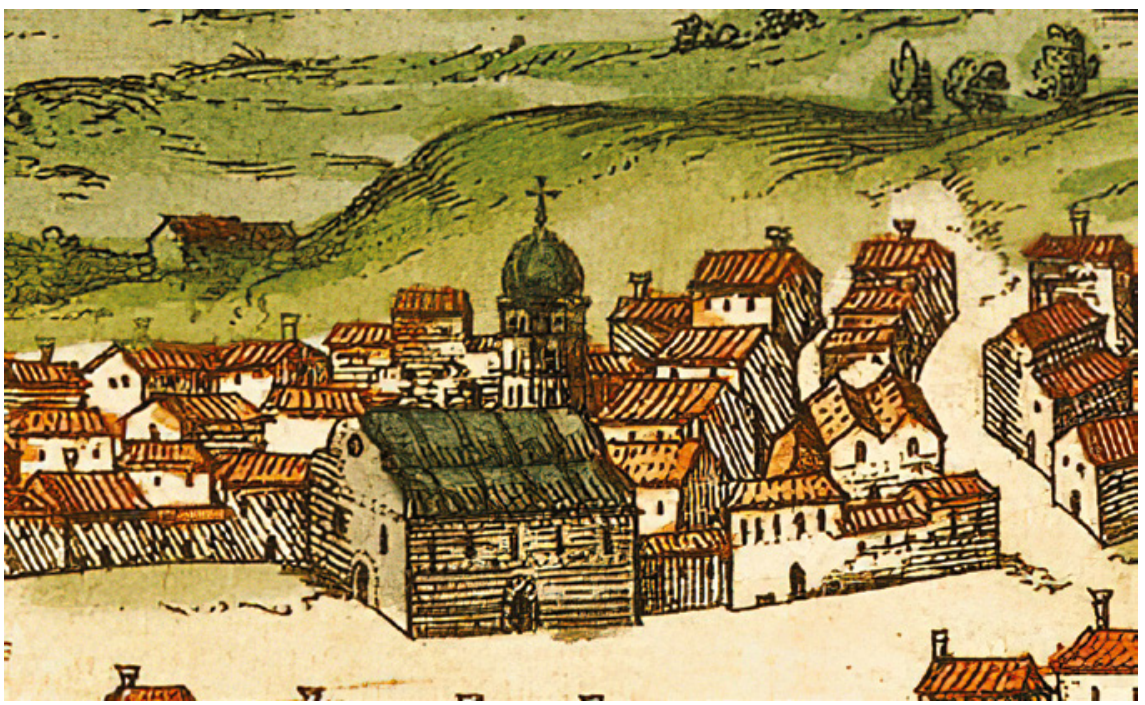

FIGURE 31 The Augustinian monastery of Corfu, c. 1575. Detail of Fig. 15

by donations from the pious. ${ }^{202}$ After the fortification of the borgo and the expansion of the town and especially after the construction of the new Latin cathedral of St Jacob, the Annunziata became a part of the 'heart' of the new town, situated in the Piazza San Giacomo, near the cathedral, the bailiff's palace and the archbishopric (Pallazzo Pubblico and Pallazzo Archiepiscopale). ${ }^{203}$

The building compound of the priory was of significant size, with a large courtyard around which the monastery complex and a cemetery were built. The 14th-century building of the conventual church of the Annunziata was a three-aisled, wooden-roofed basilica with an adjoining bell tower. It was located in the corner of the plot and was orientated in deviation from the east - west axis. ${ }^{204}$ The monastery was severely damaged during the Ottoman sieges of 1537 and 1571 . As a matter of fact, in 1571 its roof was completely burnt and rebuilt with wood from the defeated Ottoman galleys. ${ }^{205}$ During the period between 1668 and 1670, the building was once again restored, and it was then that it acquired its present form. After these restorations, the

\footnotetext{
202 Asonitis 1988, 69; Agoropoulou 2004, 232, 238; Sathas 1880-1883, vol. 2, 141, Karydis 2007a, 241-242; Tsougarakis 2012, 253-258.

203 Voskopoulou 2006, 128.

204 Agoropoulou 2004, 238-239.

205 Agoropoulou 2004, 233; Giotopoulou 1997, 70; Asonitis 1988, 69.
} 
church retained the type of the three-aisled, wooden-roofed basilica, as well as many of its Gothic features. ${ }^{206}$ In its lateral aisles there were four elegant altars (two on the north wall and two on the south) in the Baroque style, adorned with colourful marbles. ${ }^{207}$ The main altar of the church does not exist today. It was probably located in the centre of the sanctuary and was covered by a large ciborium with spiral columns of red marble. Two of these pillars were used for the construction of a ciborium in the cathedral between the years 1966 and $1970 .{ }^{208}$

The façade of the church was on its narrow west side. It was very simple in form, with a round window above the main entrance (Fig. 32). The doorframe was of red marble, framed by two windows. On the north and south walls, doors, as well as two semi-circular windows, were probably opened to provide direct access to the lateral aisles. A small marble staircase led to the main entrance, to the left of which still survives an inscribed plaque, probably mentioning the donor of the church, embedded in the wall. The inscription was destroyed by the French in the 18th century. The bell tower, the only part of the monastery that remains entire, was also built in the 14th century. Unlike the rest of the churches of Corfu, the Annunziata's bell tower was not located on the east side, but on the west, near the façade of the building. Its higher part has on each side double-arched openings, above which there is a zone decorated with a trireme, the emblem of Corfu. Two bells from the church of St Saviour in Candia were placed in this bell tower, brought to Corfu by monks fleeing the island after its occupation by the Ottomans. ${ }^{209}$

As in most of the Latin churches of the island, the floor of the Annunziata's central aisle was covered with inscribed burial plaques, marking the tombs of soldiers, noble families and members of the Guild of St Joseph. ${ }^{210}$ Today, only

206 During the restoration of 1668-1670, the ceiling of the church was decorated with 18 paintings by Martino Rigoni, while the famous Cretan painter Theodoros Poulakis and his brother Christophoros painted some of the icons of the church. The decoration of the ceiling was renewed before World War II. Agoropoulou 2004, 240-241.

207 One belonged to the guild of craftsmen, carpenters and stonemasons and was dedicated to St Jacob, while the other three belonged to the fraternities of the Virgin of the Rosary, St Carlo and the Virgin of Consolation. The altar of the Virgin of the Rosary remained in the church of the Annunziata up until 1746, when the fraternity built its own church. Agoropopoulou 2004, 240-241.

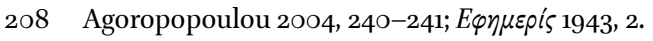

209 Agoropoulou 2004, 239.

210 Rusconi 1952, 248. 


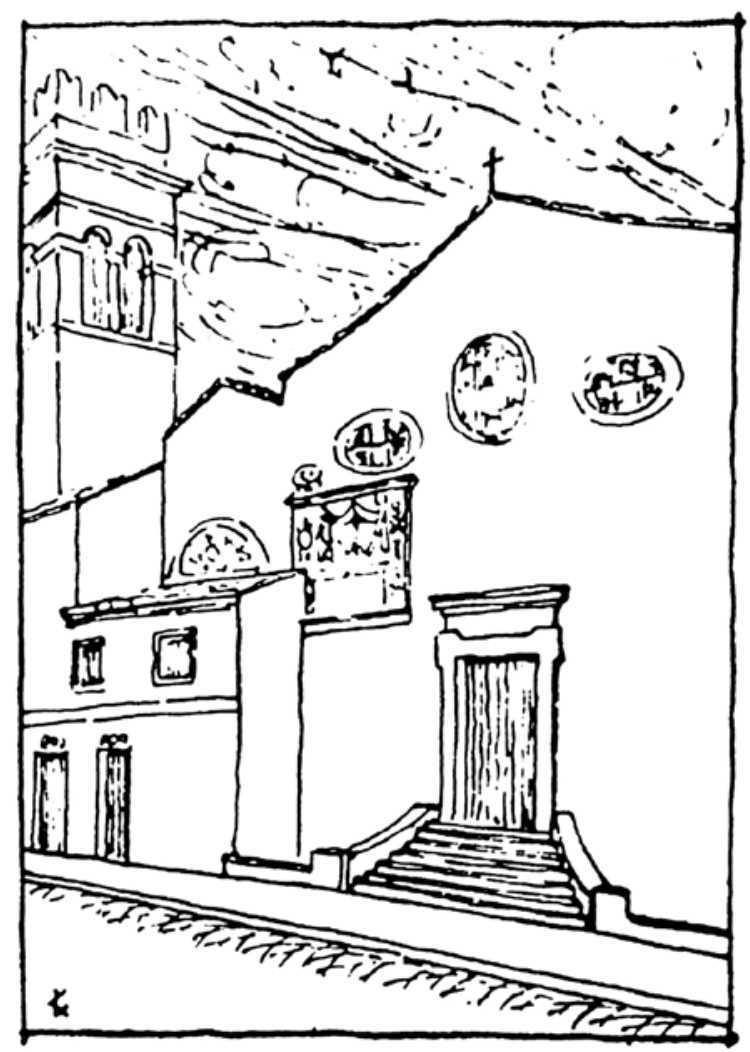

FIGURE 32 The Augustinian conventual church of the Annunziata, Corfu, drawing after L. Crema

one of these plaques remains in situ, located at the interior side of the remaining wall of the façade, while the others have been moved to the cathedral. ${ }^{211}$

The monastery of St Mary of the Annunciation of Corfu was the last of the Augustinian monasteries to survive in Greece. In 1797, when the French occupied the island, the monastery of the Annunziata, along with the rest of the Latin religious institutions of the town, was abolished (with the exception of its conventual church), and its property was confiscated. In 1916 there seems to have been a restoration of the church and the buildings of the monastery. ${ }^{212}$ During World War II, in 1939, the priory and its surrounding area suffered severe damage from German bombings. The monastery complex was later

\footnotetext{
211 Agoropoulou 2004, 241.

212 Papageorgiou 1920, 219.
} 


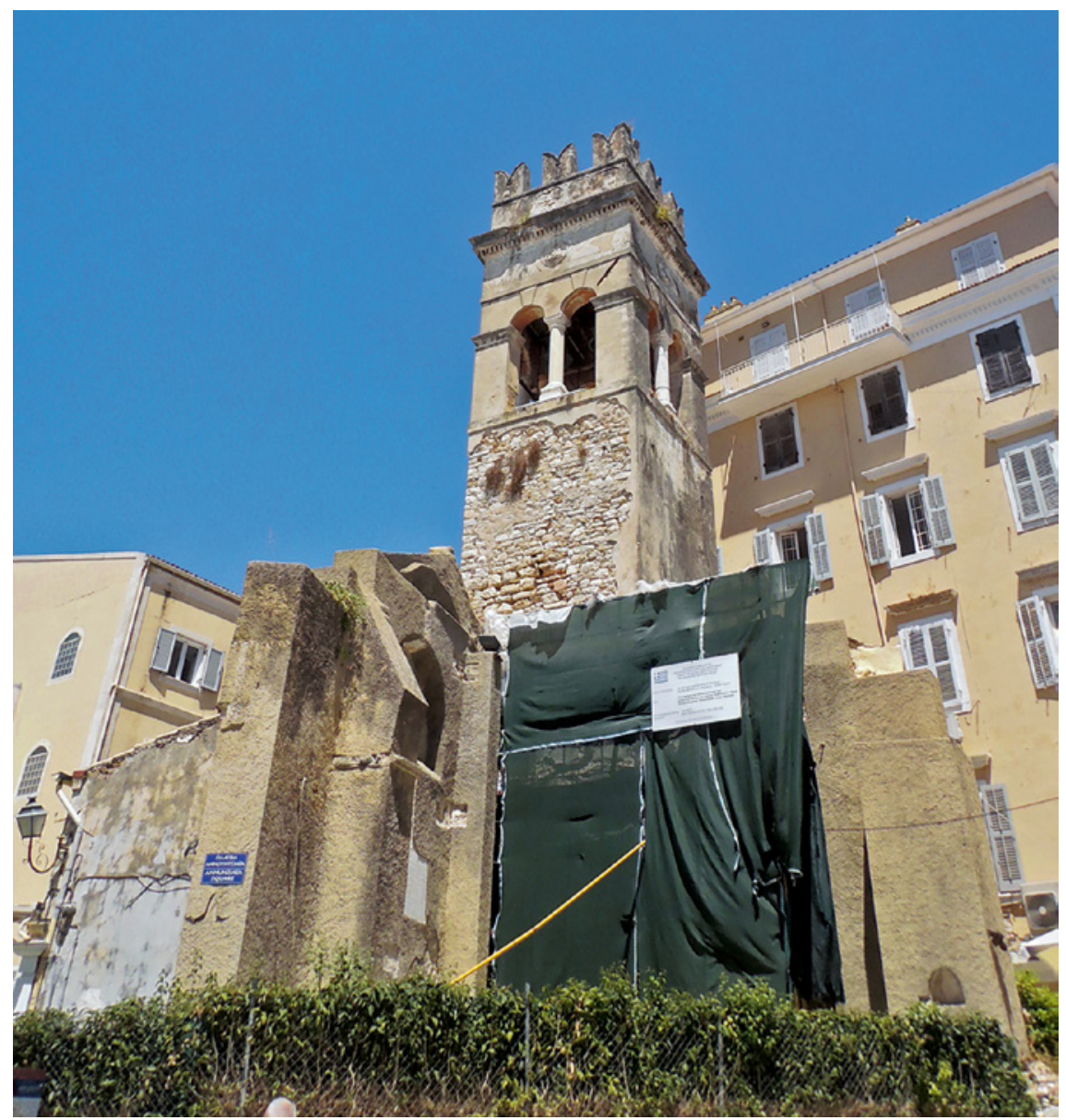

FIGURE 33 The bell tower of the Annunziata and the remaining part of the Augustinian conventual church in its present state

completely demolished, and the space it occupied was converted into a public square. The only building that survives today from the large Augustinian monastery, which had been so significant for the medieval town of Corfu, is its bell tower and a part of the west wall of the church of the Annunziata (Fig. 33).

\subsubsection{Liturgical Habits}

The Augustinian monastery was a destination of processions either beginning from or ending at the Latin cathedral. Both religious and public ceremonies of significant importance for Venice were held in the church of the Annunziata, 
indicating the prominence of the priory for the Latin community of Corfu, which had chosen this monastery to promote the glory of the Serenissima Repubblica di San Marco.

Most of the official ceremonies performed in the monastery were not purely religious, but they fell into the category of the processioni pubbliche. This type diverged from the common litanies. In practice, they were a combination of a religious litany and an official glorification of the Serenissima. ${ }^{213}$ Ceremonies of this type were held in the Augustinian monastery on 25 March, the day of the Annunciation, a date that coincided with the anniversary of the establishment of the Venetian Republic, and on 25 April, the commemoration day of St Mark. ${ }^{214}$ It is clear that both these ceremonies, particularly the one commemorating Venice's protector saint, had a deeper political meaning, and the participation of the Orthodox clergy, who recited laudi in honour of Venice and all its representatives on a central, local, political and military level, served as an expression of the submission (vassallaggio) of the largest part of the island's population, the Greek Orthodox.

The only purely religious official public celebration held in the church of the Annunziata was the commemoration day of Sts Sebastian and Fabian on 20 January. A procession starting from the cathedral, with both religious and secular representatives of the Latins and the Greeks, arrived at the church, where a Latin liturgy was performed. Even though the day had no political connotations, after the liturgy the Greek protopapas delivered a speech eulogising the Serenissima and emphasising the voluntary submission and the obedience of the island and its inhabitants to the Repubblica di San Marco. ${ }^{215}$

The fact that these public celebrations of significant importance for Venice were held at the church of the Annunziata indicates the prominence of the Augustinian monastery for the Latin community of Corfu. This importance is certainly not reflected in the travelogues. As mentioned above, very few pilgrims mention the monastery, and all of them refer just to the existence of an Augustinian monastery in the borgo, not providing any further information about it. The first to mention the Augustinian priory was Wilhelm Tzewers (1477-1478), who reported that the Augustinian and Franciscan friars

213 Members of both clergies and representatives of the local government left the Latin cathedral after the end of the liturgy and went in procession to another church, in this case the Annunziata, where, after the reading of the Gospel by the Latin archbishop, they performed a ceremony in honour of the Republic. Nikiforou 2014, 43; Tsitsas 1969, 130.

214 Papageorgiou 1920, 75, 219; Nikiforou 2014, 51, 56-57, 61; Tsitsas 1969, 154.

215 Papageorgiou 1920, 154-155; Nikiforou 2014, 52-53, 56. 
provided accommodation for the travellers, but that both the monasteries were very poor. ${ }^{216}$

In the narrative of both of his pilgrimages (1480, 1483-1484) the German Dominican friar Felix Fabri mentions the existence of the monastery in the borgo. ${ }^{217} \mathrm{~A}$ similar terse reference was made by the pilgrim Georges Lengherand of Mons (1485-1486). ${ }^{218}$ The Franciscan friar Paul Walther Guglingen, who visited the island in 1482, mentioned that, just like in the Franciscan monastery, the liturgies in the Augustinian priory were not held following the rituals of the Latin Church. ${ }^{219}$

The case of the Augustinian monastery is indicative of the difference of perceptions as far as the local inhabitants and pilgrims are concerned. One of the most, if not the most, eminent Latin religious institutions of Corfu seems to be of no significant importance to the pilgrims visiting the island. As in the case of St Francis, this could easily be explained by the fact that it certainly was not an imposing building complex in terms of architecture and decoration and definitely much humbler than the ones the pilgrims had already visited before arriving on the island. In addition, and most importantly, it does not seem to have possessed any cult objects, relics or icons, attractions that pilgrims were eager to see on their journey in anticipation of their final destination, Jerusalem.

\subsection{The Latin Cathedral of Sts Peter and Paul}

The third Latin religious destination in the town of Corfu that was mentioned in the travelogues is the Latin cathedral (Fig. 34). The church of Sts Peter and Paul, located inside the walls of the castle of Corfu, was the cathedral of the island since the Byzantine era. There are no specific indications about its date of construction, but it is considered to have existed already from the 1oth century. ${ }^{220}$ Inside the cathedral the Orthodox kept some of the relics of the legendary founders of the Corfiot Church, Sts Jason and Sosipater, as well as the relic of St Arsenius, Bishop of Corfu. ${ }^{221}$

In 1267, when Corfu came under the rule of the Angevins, the church was converted for Catholic use and served as the cathedral of the island, used also

\footnotetext{
216 See $n .192$ above.

217 'Suburbia sunt multo majora civitate, et in una sunt duo conventus fratrum, scilicet Minorum et S. Augustini [...].' Hassler 1843-1849, vol. 3, 351.

218 Ménilglaise 1861, 96.

219 See n. 194 above.

220 Leontsini 2014, 44; Petridis 1971, 432-446.

221 Nikiforou 2014, 83; Papageorgiou 1872, 16; Papageorgiou 1920, 187-189; Petridis and Emerau 1921, 442; Soustal and Koder 1981, 178; Scholz 1997, 148, 287, Karydis 2007a, 235.
} 


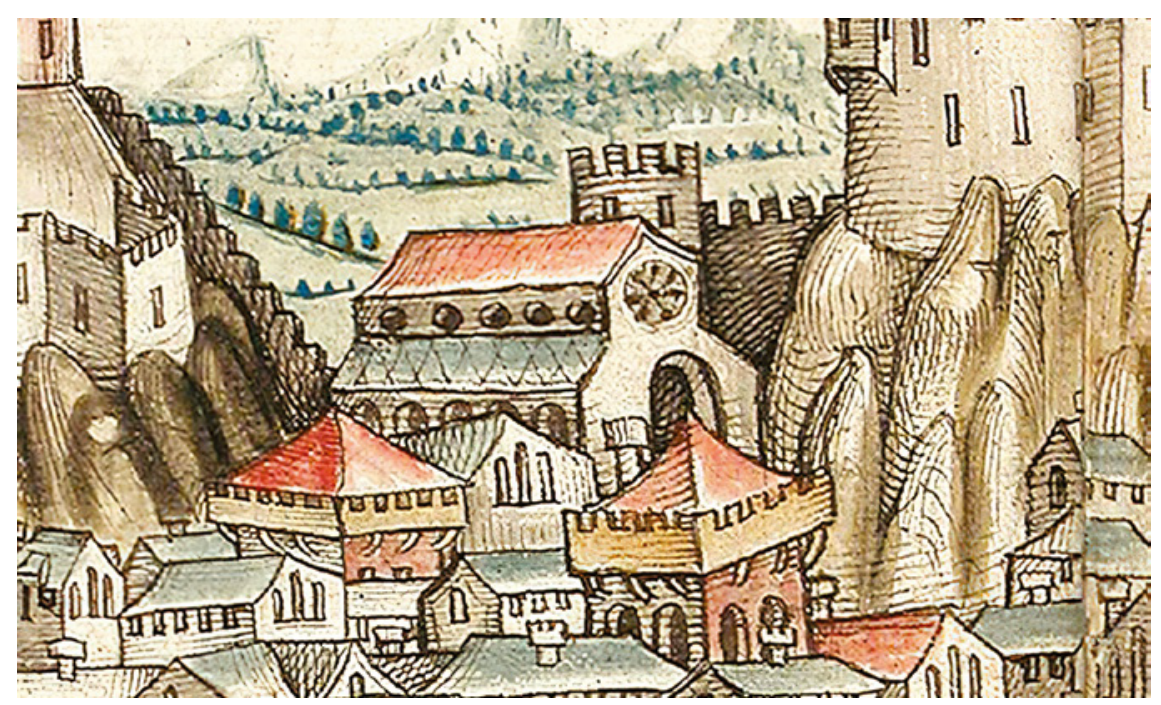

FIgURE 34 The cathedral of Corfu, c. 1487. Detail of Fig. 14

by the Venetians, until 1633. The aforementioned relics continued to be kept inside the church, but the Greeks were allowed to worship them, as well as to perform liturgies for their patron saint, on a separate altar on predetermined days of the year. ${ }^{22}$ St Arsenius was also venerated by the Latins of Corfu. On the day of the commemoration of his death, a liturgy in his honour, followed by a procession of his relics, was held in the cathedral with the participation of both the Latin and Orthodox clergies. ${ }^{223}$

In the 13th century Georgios Vardanis, Archbishop of Corfu, restored the church. As part of the restoration programme, the cathedral was decorated with new frescoes. ${ }^{224}$ Vardanis also constructed his tomb, where he had an epigram inscribed, in the cathedral. In 1228 the active archbishop placed in the cathedral, carved on a stone, the edict (golden bull) by which the Emperor Theodore Doukas had renewed the rights and privileges of the Corfiot Church. ${ }^{25}$ As part of his restoration programme, Vardanis also repaired the chapel built above the tomb of St Arsenius right next to the cathedral. ${ }^{226}$ As evidenced by surviving epigrams of the archbishop, the saint's chapel was in a very poor condition, without doors and badly guarded. He therefore put new doors with stone

\footnotetext{
222 Mustoxidis 1848, 409-412; Karydis 2007a, 235; Tsitsas 1969, 147; Papageorgiou 1872, 19; Nikiforou 2014, 79.

223 Tsitsas 1969, 147; Papageorgiou 1872, 21; Nikiforou 2014, 79-87.

224 Leontsini 2014, 44; Galoni 2006, 294; Asonitis 1999, 47.

225 Galoni 2006, 294.

226 Leontsini 2014, 44; Galoni 2006, 294; Asonitis 1999, 47.
} 


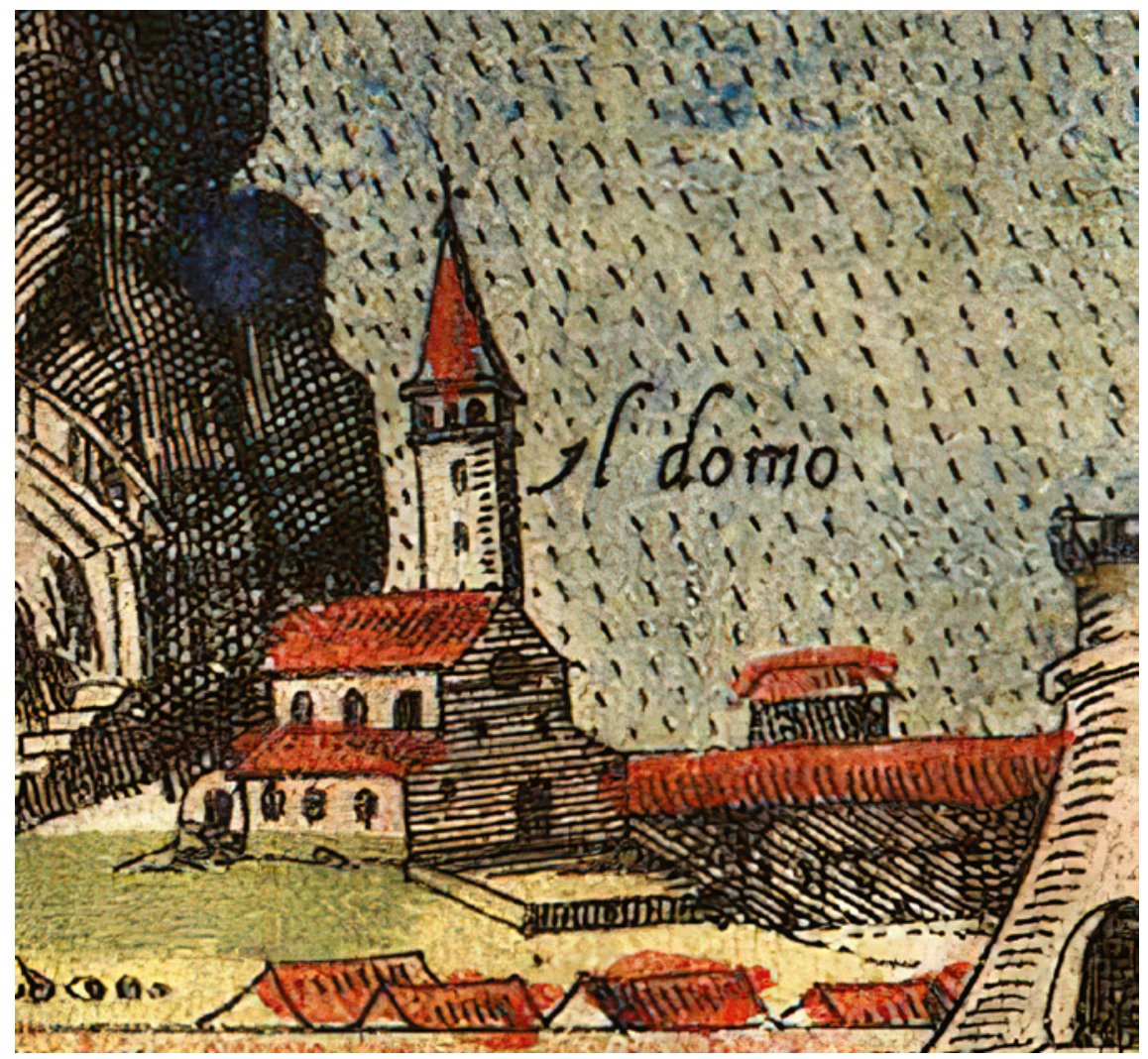

FIGURE 35 The cathedral of Corfu, 1573. Detail of Fig. 12

eaves, on which he probably also had an epigram carved, exhorting the pious to respect the place where the holy relics were kept. ${ }^{227}$

During the Venetian occupation of Corfu, the church, which continued to serve as a cathedral, but neglected by the archbishopric of the island, was almost in ruins in 1410. The city of Venice offered to undertake the restoration by binding part of the incomes of the archbishopric and the monasteries of the town. ${ }^{228}$ However, no restoration works were done in the following years, resulting in the archbishop requesting the money back to repair the building in $1414 .^{229}$ The Italian pilgrim Pietro Casola, who visited the island in 1494, clearly mentions that the cathedral was not in a good state (Fig. 35$){ }^{230}$

227 Galoni 2006, 294-295.

228 Karydis 2007a, 235; Sathas 188o-1883, vol. 2, 237.

229 Karydis 2007a, 235; Sathas 188o-1883, vol. 3, 51.

230 See n. 241 below. 


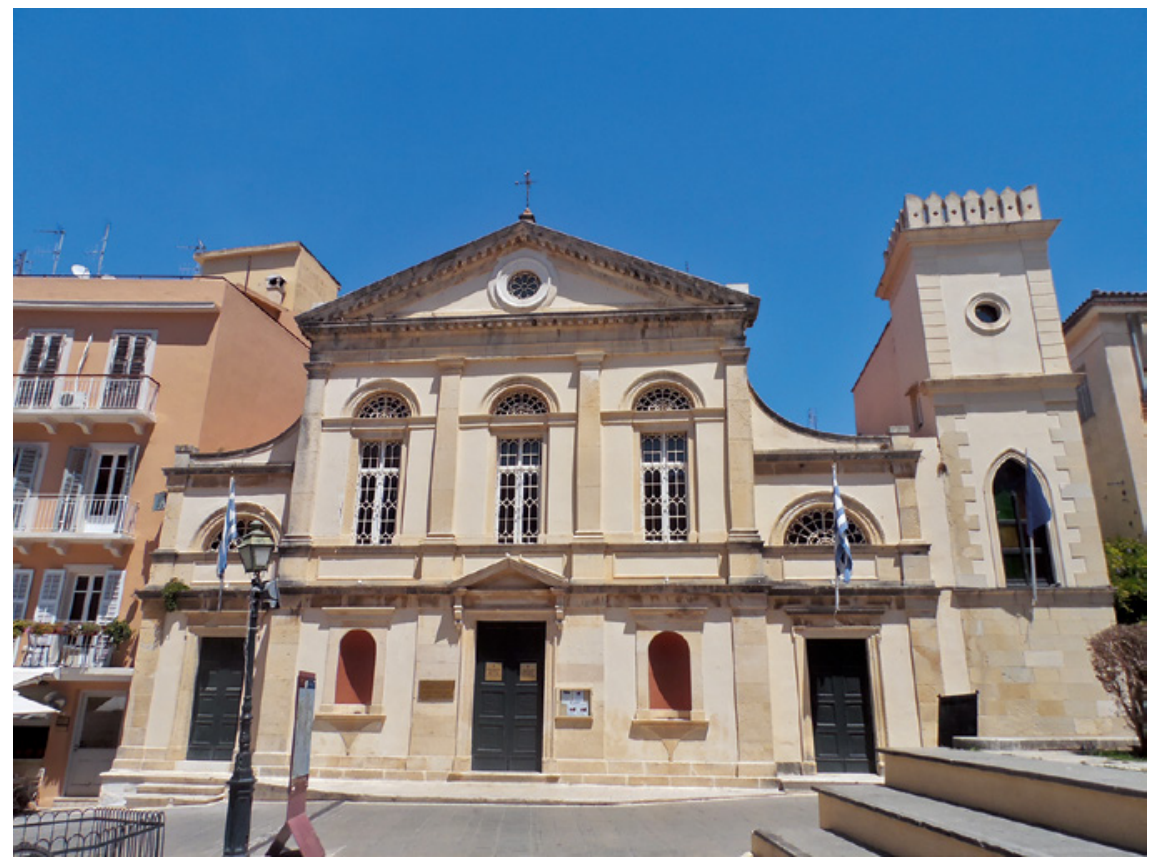

FIGURE 36 The church of St Jacob, the Latin cathedral of Corfu since 1633

In 1633 , for reasons of safety, the cathedral was moved to a newly founded church dedicated to St Jacob, built outside the castle (Fig. 36). ${ }^{231}$ After that point, the church of Sts Peter and Paul was referred to as Duomo Vecchio, until it was finally destroyed by an explosion in the gunpowder repository on 11 November 1718.232 After its destruction a much smaller church, also dedicated to Sts Peter and Paul, was built on its debris for the use of the inhabitants of the castle and the soldiers. At the same time the Orthodox built a chapel dedicated to St Arsenius near the church. ${ }^{233}$ The 18th-century small church of Sts Peter and Paul continued to be used by both Latins and Orthodox until at least $1739 .{ }^{234}$ Today no traces of the church or the chapel survive.

The cathedral of Sts Peter and Paul seems to have been the only Latin church in the town of Corfu to possess saintly relics, as well as, according to

231 Leontsini 2014, 44; Tsitsas 1969, 148; Papageorgiou 1872, 20; Nikiforou 2014, 80; Karydis 2007a, 236; Agoropoulou 2004, 243.

232 Karydis 2007a, 236.

233 Karydis 2007a, 236; Leontsini 2014, 44; Papageorgiou 1872, 19.

234 Nikiforou 2014, 274. 
two pilgrims' reports, a piece of the True Cross. ${ }^{235}$ As in the case of all the Latin churches of the town, it is referred to in very few travelogues. The first to mention it is Ulrich Brunner in 1470, stating that the relic of St Arsenius was kept in the church and that the bishop was a Dominican friar. ${ }^{236}$ Felix Fabri, in the narration of his second pilgrimage (1483-1484), supports this. ${ }^{237}$ In 1480 two French pilgrims, Pierre Barbatre and the anonymous author of Le voyage de la saincte cyté de Hiérusalem, pointed out that, at the time, the Franciscan friars were officiating at the cathedral following the Latin rite and using the Latin language, while in most of the churches of the town the service was held in Greek. $^{238}$

The Franciscan friar Paul Walther Guglingen, who visited Corfu in 1482, is one of the two pilgrims who, besides the relics known to be housed in the cathedral, the body of St Arsenius and those of Sts Jason and Sosipater, mentioned a piece of the True Cross. ${ }^{239}$ Ten years later the pilgrim Dietrich von Schachten (1491-1492) also remarked on seeing a piece of the True Cross, placed in a small cross-shaped silver reliquary, in the cathedral. 240

Returning to Paul Walther Guglingen's narrative, it is obvious that he was not at all impressed by the church building, since he described it as a 'miserable church with very few altars', an impression shared by the Italian pilgrim Pietro Casola, who visited Corfu in 1494:

I went into the cathedral, but I will not write more about it, because I did not find anything there worthy of record, for there is no single vestige of a choir in the said church, nor sign of its being a collegiate church. In the said church, as I was told, the body of Santo Arsemo [St Arsenius] reposes under the altar. I saw two bells in a window; I think that must be the bell tower, because there is no other. ${ }^{241}$

235 Paul Walther Guglingen (1481-1483), Sollweck 1892, 78; Dietrich von Schachten (14911492), Röhricht and Meisner 188oa, 179.

236 'Item zu Corfu im thum leyt sanctus Arsenius begraben, und ist ein bistum und der ytzundt ein bischoff do ist, der ist ein prediger münch und ist ytzündt ein weyebischoff $\mathrm{zu}$ Venedig [...].' Röhricht 1906, 21.

237 'In prima mea peregrinatione erat episcopus ecclesiae frater ordinis nostri sed obiit.' Felix Fabri's first pilgrimage took place in 148o. Hassler 1843-1849, vol. 3, 380.

238 See n. 99 above.

239 See $n .246$ below.

240 'Item der Thumb zu Corsun ist eine schlechtte Kierchenn, da zeigett mann uns ein sielbernes Creutzlein, darienn bloss ist ein stücklein vonn dem heiligenn Creutze.' Röhricht and Meisner 1880a, 179 .

241 Paul Walther Guglingen (1481-1483): '[...] est miserabilis ecclesia cum paucis altaribus'. Sollweck 1892, 78. Pietro Casola (1494): 'Sono stato in la sua giesia cathedraie; non ne 
2.6.1 The Relic of St Arsenius

The patron saint of Corfu, whose relic was kept and worshipped in the cathedral, was the first archbishop of the island and consequently a very well-known and important saintly figure for the locals, both Greek and Latin. On the other hand, it is clear that for Western travellers visiting the town Arsenius was an unknown saint of minor importance. Indicative of that is the fact that half of the pilgrims who mention his relic misspell his name.

Jan Aerts, who visited the island in 1481, appears quite confused: to begin with, the Netherlandish pilgrim, maybe because of the use of the church by both Greeks and Latins, mistakenly identified the cathedral as a Greek church and St Arsenius as St Erasmus, a saint who was much more familiar to Westerners. ${ }^{242}$ It is not uncommon for pilgrims visiting Greece to misunderstand the names of the saints whose relics were shown to them, given that they were probably told to them in Greek, a language with which they were not familiar. The same applies in the case of Wolfgang Zillenhart (1495-1496), who refers to a St Archerito. ${ }^{243}$

None of the pilgrims who mention St Arsenius's relic provided a description of the reliquary. According to tradition, the saint's body was enshrined in the altar of the cathedral. ${ }^{244}$ It is also known that on the day of the commemoration of his death a liturgy in his honour was held in the church, followed by a procession of his relics. ${ }^{245}$ What is not clear is the parts of the relic that were displayed and venerated on a permanent basis, since according to the narrations of the pilgrims they could see and prostrate to only one finger of the saint: 'In the cathedral church reposes the holy body of St Arsenius [...] And some pilgrims went in the sepulchre and saw, bare, a finger of St Arsenius and

scriverò altro porche non glì o trovato cose degne de mandare a memoria, non trovando in dicta giesia uno solo vestigio de coro, ne de essere giesia collegiata. In dicta giesia, como me fu dicto, li repossa el corpo do santo Arsemo, in lo altare. Vidi due campanelle in una renestra; credo sii el suo campanile, per non osservi de altri.' Paoletti 2001, 137 (the translation of the extract is from Newett 1907, 186).

242 'In de Griecksche kercke, staende by een der voorschreve kasteelen, te water-waerts, worden oock sommige heylige Reliquien in grooter reverentien gehouden, onder al sagh ick daer eenen vinger van St. Erasmus, van wien in't boeck der Vaders veel beschreven staet.' Van Nispen 1652, 149.

243 'Item zwischen den zway schlosse ligt ain kirch, haist zu sant Archerito, und ist ain ertzpistum [...].' Gebele $1932-1933,81$.

244 Papageorgiou 1872, 16; Petridis and Emerau 1921, 442; Papageorgiou 1920, 187-189; Soustal and Koder 1981, 178; Scholz 1997, 148, 287.

245 Tsitsas 1969, 147; Papageorgiou 1872, 21; Nikiforou 2014, 79-87. 
a piece of the True Cross and other saintly relics [...].246 It could be assumed that parts of the body had been separated and were kept in reliquaries in order to be visible to the worshippers. ${ }^{247}$

\subsubsection{Liturgical Habits}

As mentioned above, ever since the holy relics of the Greek cathedral of Corfu were seized along with the church by the Angevins, the Orthodox were given the right to venerate them and perform their own liturgies on eight predetermined days of the year. ${ }^{248}$ On the day of the commemoration of St Arsenius's death, 19 January, a pompous official celebration with the participation of both clergies was held in the Latin cathedral. This celebration included a common vespers and liturgy from the clergies of both rites on the eve and the day of the saint's feast, respectively, in the presence of the Venetian authorities and the representatives of the city council. It has been suggested that the common celebration was established after the erection of the new cathedral of St Jacob, but archival documents attest to its existence before $1633 .{ }^{249}$

The rite of the common celebration of 19 January is described in the 'Ceremoniale che si osserva nelle funtioni in cui si uniscono i due riti', a manuscript dated to $175^{8}$ preserved in the Historical Archive of Corfu. ${ }^{250}$ There is also a first codification of this rite dated to 1645 that differs very slightly from the subsequent codifications, allowing the assumption that the celebration was already well-established by that time. ${ }^{251}$ In addition, a report of the Latin Archbishop Benedetto Bragadin to the Secretary of the Council of the Sacra Congragazione della fede, dated 1632, refers to the co-celebration of St Arsenius's feast as 'customary'. 252

246 Paul Walther Guglingen (1481-1483): 'In summa ecclesia requiescit corpus sacrum sancti Arsenii, et sunt ibi canonici. Et aliqui peregrini fuerunt ad sepulchrum et viderunt nude unum digitum sancti Arsenii et unam partem sancte crucis, et alie reliquie sanctorum [...].' Sollweck 1892, 78. The saint's finger was also mentioned by Jan Aerts (1481-1484). Van Nispen 1652,149 .

247 Relics of St Arsenius are today kept and venerated in three churches on Corfu, the Orthodox metropolitan church, as well as two churches dedicated to St Arsenius in the villages of Lefkimmi and Valaneio. Tsitsas 1969, 15\%; Papageorgiou 1820, 11-19; Nikiforou 2014, 81.

248 For the exact dates, see Tsitsas 1969, 148; Papageorgiou 1872, 21.

249 Tsitsas 1969, 15o; Mustoxidis 1848, 410; Nikiforou 2014, 81-82.

250 Papageorgiou 1872, 21-23.

251 Nikiforou 2014, 82, n. 71.

252 The surviving description of the rite of the celebration of St Arsenius's feast concerns the ceremony performed at the new Latin cathedral of St Jacob and includes services performed by Latins and Greeks following both rites, as well as the active participation 
The co-celebration in honour of an Eastern saint by Latins and Orthodox, with a simultaneous liturgy of both rites, was not a common phenomenon. Less than two centuries after the end of the Venetian occupation, Spyridon Papageorgiou, who studied the history of the Church of Corfu, mentions that '[...] during the saint's feast the following peculiar practices were carried on according to the provisions of the rite [...]. ${ }^{253}$ St Arsenius was venerated on the island from the Byzantine period, and his relics were seized by the Catholics, while his cult was preserved by the Angevins and the Venetians and was incorporated into the sacred hierarchy of Venetian Corfu. This phenomenon can be understood only under the spectrum of the particularity of Venetian religious policy in the areas of its Greek acquisitions. By incorporating the patron saint of the island, the Serenissima was aiming to ratify its authority, while the co-celebration of the same patron saint was also intended to enhance the link between the Latins and the Orthodox, while keeping the Greek clergy satisfied by being able freely and equally to perform Orthodox liturgies in Latin churches. In general, the Venetians made serious efforts to maintain the delicate balance between their Orthodox subjects and the Catholic Church. A parallel to the appropriation of an established cult by the Venetian authorities can be seen on Crete, with the cult of St Titus in Candia, whose relic was also kept in the Latin cathedral and whose feast day was celebrated by a procession with the participation of both clergies. ${ }^{254}$ Furthermore, a similar phenomenon, but to a much larger extent, emerged in Corfu after the $15^{\text {th }}$ century with the translation to the island of the relic of St Spyridon.

The cathedral of Corfu was treated by the pilgrims in the same way as the rest of the churches and monasteries of the town. They were definitely not impressed by the building, while some of them clearly express their disappointment. Their attitude was similar in regard to the saintly relics held in it. The saints were unknown to them, so they evaluated their bodies as relics of minor importance, while most of them, even though they were aware of their existence, did not actually see them. As in the case of the other churches in the town, exempting maybe the Franciscan monastery, the different perspective between locals and visitors is obvious. In general, locals live and perceive the reality of each place, while for pilgrims the reality is a network of places leading to a specific destination. Natives seek the protection of saints or cult objects connected to their town or island, while travellers treat each stop on their way

of the town's authorities and people. See Tsitsas 1969, 150-152; Papageorgiou 1872, 21-23; Nikiforou 2014, 82-85.

253 Papageorgiou 1920, 77.

254 Georgopoulou 2010, 486. 
as a step that brings them closer to their goal. Therefore, the fact that the most prominent church of the town of Corfu from the point of view of the locals, where the relics of their patron saint were kept and venerated, was sparsely mentioned in the travelogues should not come as a surprise.

The church of the Virgin in Kassiopi stands out during the Middle Ages, at least as far as the pilgrims are concerned, as the most renowned church of Corfu. The area had been invested with transcendental properties ever since the ancient period, when it was protected by Cassios Zeus. The religious importance of the site, always connected to its location and inextricably linked to the needs of the sailors, was amplified in the Middle Ages, and the Virgin became its sanctifying divine power. Over the course of time, the fame of the site was enhanced as it was endowed with legends of monsters, miracles and divine power that were dispersed first and foremost by the seafarers. Kassiopi has the most intense and uninterrupted presence in the travelogues while at the same time the most long-lived cult, even though it evolved through time. The small church of the Virgin seems to address the core of the religious pilgrimage, as well as the curiosity of a traveller, combining legends of monstrous creatures, miraculous interventions and divine protection with, for a Western visitor, extraordinary architecture, decoration, customs and cultic practices, as well as an evocative interaction with its surrounding landscape. Its location, providing a safe anchorage after a particularly dangerous sea passage, was definitely a significant factor in its popularity, while the role of the seafarers in promoting the site was undeniably critical, and the local actors served in their turn in its formation. After all, the Virgin Kassopitra's cult was recognised and respected also by the Latins, and the site had been a place of devotion for different confessional groups prior to the arrival of the pilgrims. Concluding, it would be safe to say that the site owes its importance to its geographical location, its sacredness to the church of the Virgin and the icon housed in it and its fame to its association with the circumstances of navigation and the mariners who propagated it. The history of this site is reflected in written sources and oral tradition, as well as in its materiality, as expressed in architectural structures, ornaments, forms of lighting and of course the cult object. Following the evolution of these elements through the centuries, it becomes clear that, beyond the importance of the port and the church for the locals and the mariners sailing through the area, it was its frequentation by pilgrims that elevated it to an international level by turning it into an important stop on the sea route to Jerusalem. 
As far as the port and town of Corfu are concerned, the pilgrims seem to have approached them more with the curiosity of a traveller, rather than as religious visitors. Having passed through the Strait of Butrint, they also crossed a linguistic and religious border from the Latin world to the Greek-Byzantine one. On Corfu they encountered for the first time a Greek Orthodox population with strong traditions and they had the opportunity to visit Orthodox churches and see the 'alternative' way to be Christian. ${ }^{255}$

The complexity of a Levantine society, as expressed in all aspects of life on Corfu, was fascinating for the travellers, who often preferred to describe this new and strange reality than the churches or monasteries of the town. The same applies to all the areas of this study, but the big towns of Corfu and Candia offered Western visitors a rich variety of new experiences. Thus, travelogues that mention Corfu offer more 'anthropological' observations than information about the religious institutions of the town, which lacked the elaborate architectural forms and decoration to which they were accustomed and were thus considered poor and unimportant. The Orthodox, on the other hand, seemed to intrigue pilgrims in every aspect. Western travellers visited and described their churches, the 'peculiar' inclination of Greeks towards the veneration of icons and their special devotion to the Virgin, as well as the way they tended to and venerated their saints' relics.

What can be deduced from the above is that the town of Corfu was not a place of importance in the 'holy itinerary' of the pilgrims. The references to its churches and monasteries are impressively low for such an important port, especially when compared with the church of the Virgin in Kassiopi, which amasses more mentions than all the religious institutions of Corfu combined. There were no impressive churches or important relics to be found in the town, and it is rather obvious that the Venetian authorities were not orientated towards making the capital of the island a pilgrims' destination. Taking into consideration Venice's religious policy of tolerance in regard to its Orthodox subjects, as well as the locals' intense opposition to the Catholic religion and its representatives, the reasons why the island's rulers chose not to promote the town as a religious destination for Western pilgrims, thus risking to compromise the fragile equilibrium between the local population and the Latins, become quite clear. It is true that the Venetian authorities of Corfu were very lenient towards the Orthodox in order not to engage in doctrinal conflicts, especially from the 16th century onwards, a period when retaining the island under their rule was of vital importance to the Serenissima. Hence, the agents

255 M. Bacci: Center for Early Medieval Studies [www Document], 2017. YouTube. https:// www.youtube.com/watch?v=C7Bzygv_Cwc (accessed 28 April 2021). 
that could promote the town as a destination for religious travellers, that is, the Venetian secular as well as the religious officials, were more interested in preserving their acquisition. In the end, Corfu was in any case a very important port, both for commercial and strategic purposes, and it seems that this was enough for the island's authorities. The other agents who could have elevated the churches or cult objects of the town to holy sites, the pilgrims, did not find any interesting cultic foci to prostrate to and consequently promote, so they turned their attention to the strange and fascinating religious practices of the local Greek population. Thus it comes as no surprise that the site that overshadowed all the churches and cult objects of the island was not a Latin religious institution, nor located in the town, but was instead an Orthodox church housing a Byzantine (or of Byzantine style) icon of the Virgin, venerated by Greeks and Latins, both locals and wayfarers. 